\author{
UNIVERSIDADE LE SÃO PAULO \\ INSTITUTO DE GEOCIENNCIAS
}

\title{
OS TURMALINA GRANITOS DE PERUS, SP: ASPECTOS GEOLÓGICOS E PETROGRÁFICOS
}

\author{
DIONISIO TADEU DE AZEVEDO
}

Orientador: Prof. Dr. Horstpeter Herberto Gustavo José Ulbrich

DISSERTAÇÃO DE MESTRADO

COMISSÃO JULGADORA

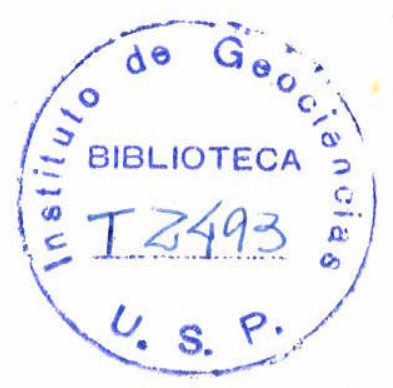

Nome

Presidente: Prof. Dr. Horstpeter H.G.José Ulbrich

Examinadores: Prof. Dr. Antenor Zanardo

Prof. Dr. José Moacyr Vianna Coutiniß)

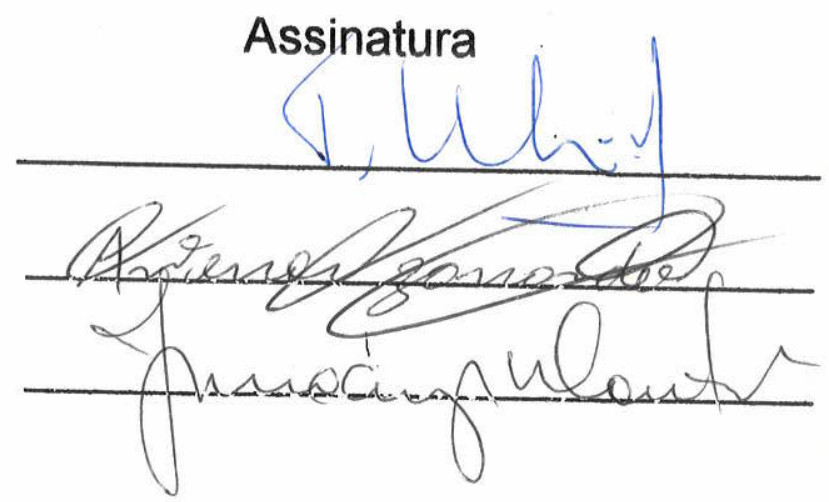

SÃO PAULO

1997 


\title{
UNIVERSIDADE DE SĀO PAULO INSTITUTO DE GEOCIENCIAS
}

\section{OS TURMALINA GRANITOS DE PERUS, SP: ASPECTOS GEOLÓGICOS E PETROGRÁFICOS.}

\author{
Dionisio Tadeu de Azevedo
}

Orientador: Prof. Dr. Horstpeter H. G. J. Ulbrich

DISSERTAÇÃO DE MESTRADO

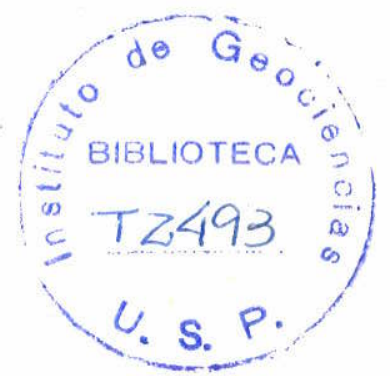

Programa de Pós-Graduação em Mineralogia e Petrologia

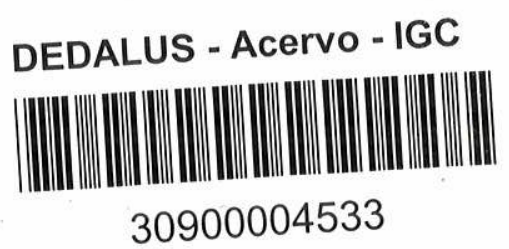

SÃO PAULO 
À Úrsula, pela paciência, compreensão e amor. 
ÍNDICE

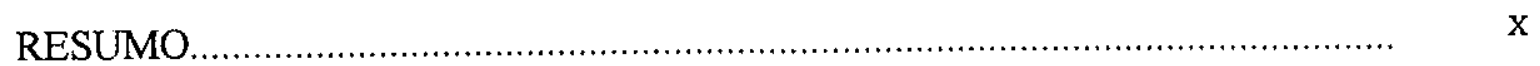

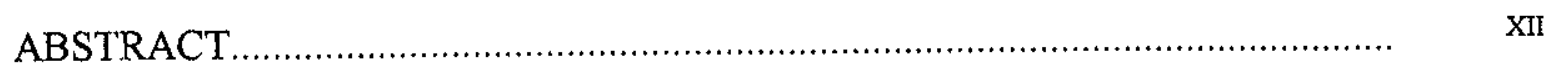

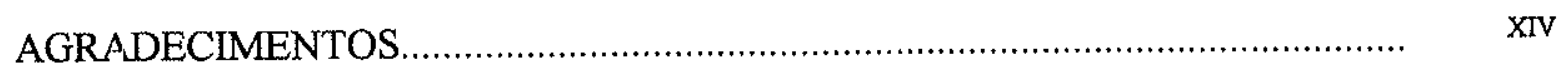

CAPÍTULO 1 - INTRODUÇÃO …………………....................................... 01

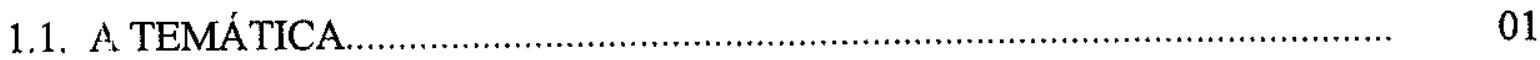

1.2. LOCALIZAÇÃO, ACESSO E BASE TOPOGRÁFICA ……………………….... 02

1.3. ASPECTOS FISIOGRÁFICOS …………………........................................ 05

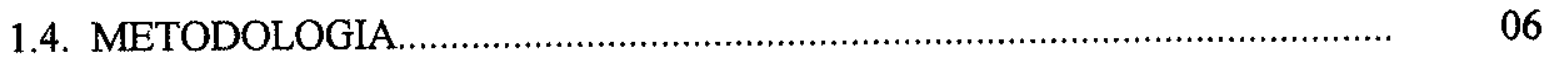

1.4.1. Andamento dos trabalhos................................................................. 06

1.4.2. Tratamento dos dados topográficos.................................................. 06

1.4.3. Análises petrográficas ...................................................................... 07

\section{CAPÍtULO 2 - O CONTEXTO GEOLÓGICO-GEOTECTÔNICO}

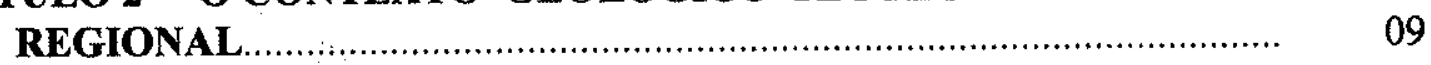

2.1. ARCABOUÇO GEOTECTÔNICO ............................................................. 09

2.1.1. O modelo geossinclinal de Ebert (1968) .......................................... 10

2.1.2. O modelo de Almeida, Hasui e coautores (1966-1981) ........................ 11

2.1.3. A Faixa Alto Rio Grande e nappes de empurrão................................. 15

2.2. AS ROCHAS METAMÓRFICAS NO DOMÍNIO SÃO ROQUE ........................ 17

2.3. A EVOLUÇÃO DO CONHECIMENTO SOBRE AS ROCHAS GRANÍTICAS DO ESTADO DE SÃO PAULO......................................... 18

2.3.1. Características gerais dos granitoides do estado de São Paulo............... 18 


\section{CAPÍTULO 3 - A GEOLOGIA DAS FOLHAS SANTANA DO}

PARNAÍBA E GUARULHOS.

3.1. EMBASAMENTO.

3.2. OS METASSEDIMENTOS E ROCHAS ASSOCIADAS: OS GRUPOS

SÃO ROQUE E SERRA DO ITABERABA.

3.3. MACIÇOS GRANITÓIDES.

3.3.1. Granitóides pré-tectônicos.

3.3.2. Granitóides brasilianos.

3.4. COBERTURA RECENTE

3.5. ASPECTOS ESTRUTURAIS

40

CAṔ́TULO 4 - GEOLOGIA LOCAL

4.1. AS ROCHAS METASSEDIMENTARES DO GRUPO SERRA

DO ITABERABA.

4.2. OS GRANITÓIDES BRASILIANOS.

4.2.1. O Granito Cantareira.

4.2.3. O granito Morro do Perus.

4.2.4. Os turmalina granitos de Perus.

As fácies dos turmalina granitos.

50

Fácies bandada.

Fácies homogênea.

Fácies pegmatóide interna.

51

Fácies pegmatóide externa.. 
4.3.1. Deformação sin-magmática nas fácies bandadas dos turmalina granitos.

CAPÍTULO 5 - PETROGRAFIA.

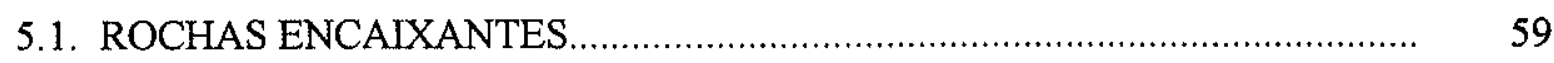

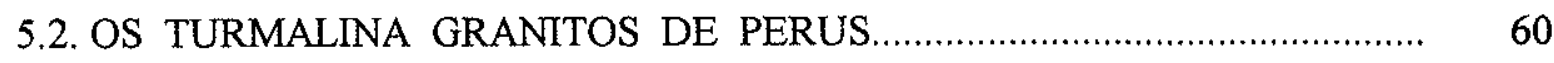

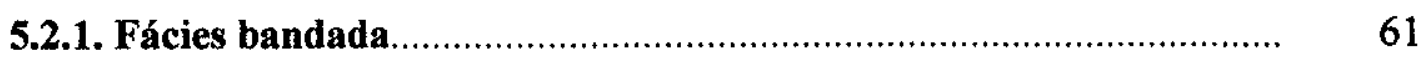

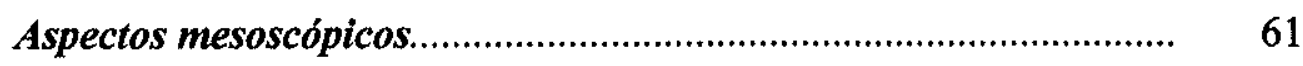

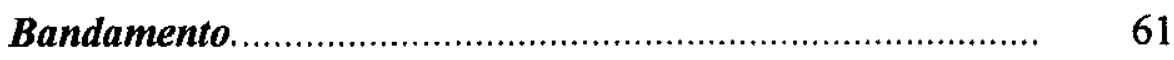

Tipos de bandamento................................................... 61

Variações modais nos niveis........................................... 64

Limites entre bandas........................................................ 66

A fácies pegmatóide interna ............................................. 66

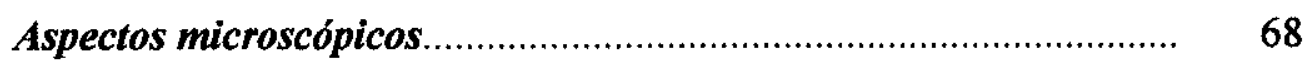

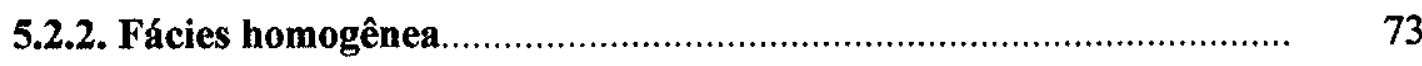

5.2.3. Fácies pegmatóide interna ................................................... 76

5.3. OS GRANITÓIDES DOS CORPOS MAIORES.......................................... 78

5.3.1. Granitóide Cantareira ............................................................ 78

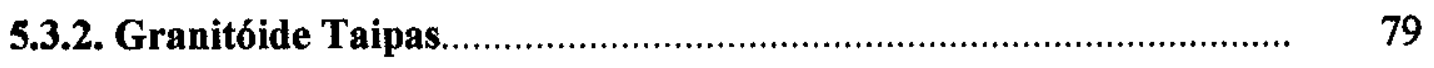

5.3.3. Granitóide Morro de Perús......................................................... 81

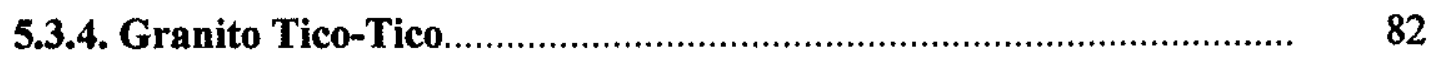

CAPÍTULO 6 - CONSIDERAÇÕES FINAIS ............................................... 86

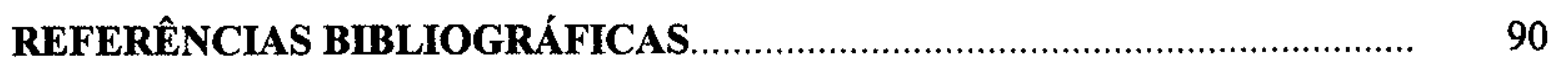




\section{ÍNDICE DE FIGURAS}

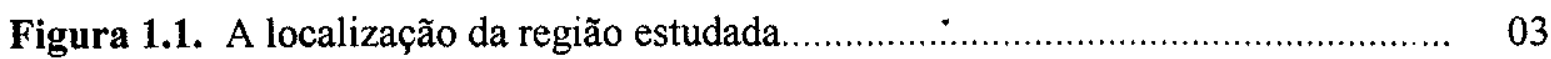

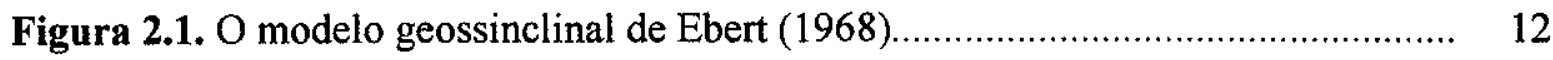

Figura 2.2. Mapa geotectônico para região sudeste segundo Hasui (1978).................. 14

Figura 2.3. A Nappe de Empurrão Socorro-Guaxupé........................................ 16

Figura 2.4. As principais ocorrências de granitóides no estado de São Paulo (Janasi \& Ulbrich, 1992) ................................................... 22

Figura 3.1. Mapa geológico regional, folhas Santana do Parnaiba e Guarulho (Anexo 1) ....................................................................... 28

Figura 4.1. Mapa geológico da região de Perus, SP (Anexo 2) ................................... 44

Figura 4.2. Diagramas de polo e roseta....................................................... 55

Figura 4.3. Esquema proposto por Ramsay (1967), mostrando dos diversos padrões de interferência em dobramentos................................ 57

Figura 5.1. Esquema mostrando o bandamento na fácies bandada ......................... 63

Figura 5.2. Algumas variações do modelo de bandamento reconhecidos

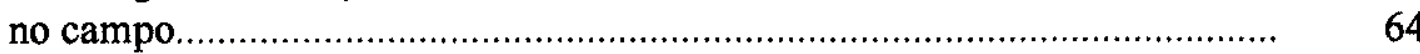

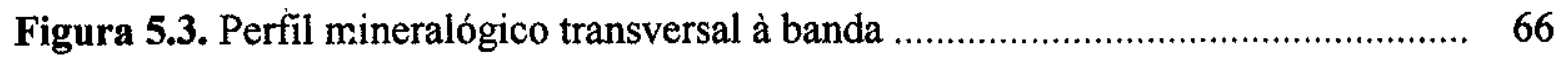

Figura 5.4. Diagrama modal Q-A-P-M para os turmalina granitos........................... 72

Figura 5.5. Diagrama modal Q-A-P-M para os granitóides dos corpos maiores............ 85 


\section{ÍNDICE DE TABELAS}

Tabela 2.1. Os domínios geológicos no embasamento paulista.

Tabela 2.2. As associações granitóides no estado de São Paulo: características e idades.

Tabela 3.1. Idades geocronológicas em rochas dos Grupos São Roque

e Serra do Itaberaba

Tabela 5.1. Dados modais para os turmalina granitos de Perus, fácies bandada e homogênea.

Tabela 5.2. Dados modais de granitóides dos maciços

Cantareira (CA), Taipas (TP) e Tico-Tico (TT). 


\section{ÍNDICE DE FOTOS E FOTOMICROGRAFIAS}

Foto 1.1. Vista geral das área de ocorrência dos turmalina granitos

(à sul do morro de Perus)

Foto 4.1. Visão geral, para NW, da frente de lavra da pedreira

Panorama, no maciço Cantareira

Foto 4.2. Vista geral do morro do Perus, desde o topo da pedreira

Fiore

Foto 4.3. A pedreira Dellantônia em julho de 1996 (Anexo 2).

Vista geral da exploração

Foto 4.4. A pedreira Botuquara em julho de 1996 (Anexo 2).

Vista geral para $\mathrm{E}$

Foto 4.5. Contato escalonado entre o turmalina granito da pedreira Dellantônia e a rocha metamórfica encaixante.

Foto 4.6. Xenólito de xistos encaixantes.

Foto 4.7. Corpo tabular concordante de turmalina granito.

Foto 4.8. Corpo irregular concordante de pegmatito, localizado em xistos.

Foto 4.9. a), b), c) e d). Ilustrações do padrão de dobramentos nos turmalina granitos.

Foto 5.1. Afloramento de biotita-sillimanita xisto

Foto 5.2. Rocha cálcio-silicática com bandamento reliquiar regular. 62

Foto 5.3. Fácies bandada na frente de lavra (pedreira Fiore).

Foto 5.4. Fácies bandada, visão de detalhe.

Foto 5.5. Fácies bandada com turmalina (pedreira Fiore).

Foto 5.6. Fácies bandada com limites em parte gradacionais.

Foto 5.7. Fatia colorida, mostrando uma banda e os níveis basal, intermediário e superior. 
Foto 5.8. Fatia colorida, identificando uma banda.

Foto 5.9. Fácies bandada na frente de lavra (pedreira Fiore)

Foto 5.10. Fácies bandada e veios concordantes de pegmatóides

(fácies pegmatóide interna) na frente de lavra...

Foto 5.11. Fácies bandada e veios concordantes

de pegmatóides (pedreira Fiore)...

Foto 5.12. Fácies bandada e veios pegmatóides concordantes e subconcordantes (pedreira Botuquara)

Foto 5.13. Relação direta entre veios pegmatóides concordantes

e discordantes na fácies bandada (pedreira Dellantônia)

Foto 5.14. Veios pegmatóides concordantes e discordantes em contato com dique na fácies bandada (pedreira Dellantônia)

Foto 5.15. a), b). Seções transversais ao bandamento, mostrando a distribuição dos minerais (nícois descruzados e cruzado)

Foto 5.16. Fácies bandada, nível basal (nícois cruzados), (pedreria Fiore).

Foto 5.17. Fácies bandada, nível intermediário (nícois cruzados), (pedreira Fiore)

Foto 5.18. Fácies bandada, nível superior, (pedreira Fiore)

Foto 5.19. Fácies bandada, nível superior, (pedreira Fiore).

Foto 5.20. Fácies homogênea na frente de lavra (pedreira Botuquara).

Foto 5.21. Fácies homogênea em fatia de rocha (pedreira Dellantônia).

Foto 5.22. Feldspato de dimensões centimétricas com intercrescimento gráfico

Foto 5.23. Fácies pegmatóide interna na frente de lavra (Pedreira Fiore).

Foto 5.24. Fatia do granito Cantareira (pedreira Panorama). 
Foto 5.25. Fatia do granito Taipas

(pedreira Construcap)..

Foto 5.26. Granito Tico-Tico

(pedreira Pedralix).

Foto 5.27. Granito Tico-Tico

(pedreira Pedralix). 


\section{RESUMO}

O objetivo principal deste trabaiho é a obtenção de um melhor conhecimento geológico e petrográfico dos turmalina granitos de Perus, SP, tentando esclarecer suas relaçס̃es com os maciços graníticos maiores que afloram nas vizinhanças. Uma parte do trabalho foi dedicada à realização de um mapa de compilação, em escala 1: 100.000, das folhas topográficas Guarulhos e Santana do Parnaiba (escala original l: 50.000), utilizando para tal os dados geológicos de quatro teses e dissertações, com a finalidade principal de mostrar, em detalhe, a distribuição dos corpos graníticos presentes na região (Cantareira, Taipas, Tico-Tico, Mairiporã, Itaqui, Itaim, Morro do Perus e vários corpos menores, estes considerados pré-brasilianos na literatura). A discussão sobre a geologia desta compilação é acompanhada de uma sinopse sobre geologia, distribuição, e idades dos granitos presentes no embasamento do estado de São Paulo, chamando-se a atenção que as idades $\mathrm{U} / \mathrm{Pb}$ mais novas sugerem que os eventos "sin-" e "tardi-tectônicos" brasilianos teriam idades em torno de 630 e $580 \mathrm{Ma}$, respectivamente.

A base do presente trabalho é um mapa de detalhe, em escala 1:5.000, da região onde são encontradas as principais pedreiras de turmalina granitos, englobando também os afloramentos do maciço Taipas e a parte centro-ocidental do maciço Cantareira. Nota-se que o primeiro aparece como três bossas principais e alguns afloramentos, marcados por matacões, aparentemente isolados, rodeados por xistos regionais (Grupo Serra do Itaberaba); é constituído por biotita granodioritos a monzogranitos porfiríticos, com hornblenda e pouco feldspato potássico na matriz. $O$ maciço Cantareira forma um marcado alto topográfico na região, separado do maciço Taipas e dos turmalina granitos por faixas de cisalhamento, como sugerido pelos mapeamentos regionais; a fácies dele predominante na região é de um biotita monzogranito, que se diferencia do granito Taipas por ser mais evoluido, não apresentar hornblenda e mostrar feldspato potássico como fenocristais e também na matriz. Foi descrito adicionalmente o granito Tico-Tico, a duas micas e com granada, embora ele esteja afastado dos turmalina granitos; petrograficamente, é um sienogranito de composição mínima, mostrando também com isto tratar-se de um produto de fusão crustal.

Os turmalina granitos, e as rochas associadas, aparecem como pequenas bossas (a maior não superior a $250 \times 150 \mathrm{~m}$ ) e uma grande quantidade de corpos pequenos (diques, veios, lentes), concordantes a discordantes, dispersos nas rochas metamórficas encaixantes, a maioria apenas visíveis como manchas restritas de alteração caolínica. As bossas de turmalina granitos e as manifestações menores (ora turmalina granitos, ora pegmatitos) estão concentradas em pequena área, localizadas em função principalmente de dois sitemas de cisalhamento: NE, predominante regionalmente, e NW; um terceiro sistema, E-W, foi documentado em pedreiras do maciço Cantareira, e parece ser subordinado. Ao longo do sistema NE, aparecem veios concordantes de turmalina granitos e pegmatitos, que podem ser encontrados mais para $\mathrm{N}$, até a região de Mairiporã, já fora da zona de mapeamento. 
Três fácies são encontradas nas bossas de turmalina granitos: bandada, homogênea e pegmatítica interna. A fácies bandada predomina nestes corpos, enquanto que a homogênea é muito restrita. A fácies pegmatítica interna aparece ora como veios corcordantes a discordantes, ora como diques e bolsões maiores, em parte ocupando partes significativas de algumas pedreiras $(20$ a $40 \%$ do total). Predominam, nas fácies homogênea e pegmatítica interna, os minerais feldspato potássico, plagioclásio (oligoclásio), quartzo e turmalina (preta, com a bege-esverdeada e a rósea aparecendo nos bolsões pegmatíticos maiores), e apatita e granada como acessórios comuns, além de uma variedade grande de minerais secundários (micas claras, fases com $U$, etc.), na fácies bandada o plagioclásio é o feldspato mais abundante. Ainda na fácies bandada, é identificada uma unidade de repetição ou banda, constituída por um nível basal (enriquecido em quartzo), um nível predominante intermediário (feldspático, com alguma turmalina) e um nível superior, característico, enriquecido em turmalina e plagioclásio; estas variações são em geral acompanhadas por leve aumento nas dimensões dos grãos (padrão normal granocrescente), por vezes sem ele (padrão normal equigranular). Estas bandas repetem-se, nos casos típicos, dezenas de vezes, sem mudanças na espessura (em geral, em torno de 3 a $7 \mathrm{~cm}$ ), padrão mineralógico, etc. Em todos os casos, as bandas aparecem deformadas com padrões que simulam redobramento. Trata-se de um fenômeno sin-magmático e não tectônico, portanto gerado durante a cristalização dos turmalina granitos. Os veios pegmatíticos concordantes sugerem uma origem por formação de magmas hiperfluidos, por concentração tardia de fluidos em locais preferenciais, como corolário do padrão bandado. As relações entre os veios concordantes e os veios discordantes, diques e bolsões pegmatíticos internos mostra claramente que os últimos representam magmas mobilizados que cortam o bandamento, num processo único $\mathrm{e}$ contínuo de cristalização e diferenciação. A origem de estruturas bandadas como estas deve apelar para mecanismos como o de convecção dupla difusiva ("double diffusive convection") e não o da simples deposição por gravidade.

Os estudos de campo não mostram claramente as relações entre os turmalina granitos e os maciços maiores, sugerindo-se na literatura que os primeiros teriam se formado por diferenciação de magmas menos evoluidos, derivado do magmatismo Cantareira. Geologia e topografia não permitem relacionar estruturalmente os turmalina granitos com o maciço Cantareira, de cristalização mais profunda e separado dos anteriores por zonas de cisalhamento. As idades até hoje conhecidas para estes dois granitóides não permitem afirmações mais categóricas, os dados sendo de 650 ou $570 \mathrm{Ma}$ para os turmalina granitos, e de $670-630$ ou 570 Ma para o maciço Cantareira. A origem dos magmas que geraram estes turmalina granitos não parece ser portanto clara, devendo ser discutida em função de dados principalmente geocronológicos e isotópicos mais definitivos. 


\section{ABSTRACT}

The main purpose of this project is to reach a better understanding of the geology and petrography of the tourmaline granites of Perus, SP, and their structural and geologic relationship with other major nearby granite occurrences. As groundwork, a compiled map is presented on a 1:100,000 scale, based on several graduate theses, depicting the geology and mainly the distribution of the granitic masses in the Guarulhos and Santana do Parnaiba sheets (the Cantareira, Taipas, Itaqui, Tico-Tico, Itaim and Mairiporã massifs, as well as other smaller and deformed occurrences, which some authors consider preBrasiliano). A discussion on the granites observed within the basement rocks of the state of São Paulo focuses on their geology, distribution and ages, showing that the latest U/Pb dates indicate an intrusion pattern with peak activity for the syn- and late-tectonic granites at about 630 and $580 \mathrm{Ma}$, respectively.

A geologic map, scale 1:5,000, constitutes the base for the present study, detailing occurrence and distribution ot the tourmaline granites and associated smaller outcrops, as well as those of the Taipas and the central-western part of the Cantareira massif. The Taipas granite is constituted by three main separate stocks and some smaller outcrops, surrounded by the Serra do Itaberaba Group (schists) as country rocks; it is a porphyritic biotite granodiorite to monzogranite, with hornblende and very little $\mathrm{KF}$ in the matrix. The Cantareira massif forms here a prominent topographic height, separated from the Taipas granite and the tourmaline granites by shear faults, as suggested by regional mapping. The locally predominant facies is a porphyritic biotite monzogranite, more evolved than the Taipas rock, with no honblende and KF in the matrix. The rocks of the Tico-Tico massif, further away, were also described; it is a two mica syenogranite with garnet, with a composition clearly reflecting origin by melting of crustal rocks.

The tourmaline granites, and associated rocks, are found as small stocks (the larger one about $250 \times 150 \mathrm{~m}$ in size) and many smaller concordant or discordant bodies (veins, lenses, dikes), within the country schists, frequently observed only as white alteration patches. The stocks (tourmaline granites) and lesser bodies (either granites or pegmatites) are concentrated within a rather small area, defined by two shear systems: one trending $\mathrm{NE}$, regionally predominant, and another with a NW trend. A third system, E-W, is subordinate and was observed in quarries within the Cantareira granite. Smaller concordant bodies were observed in the NE shear system, to the $\mathrm{N}$ of the mapped area, up to the Mairiporã region.

The tourmaline granite stocks present three different petrographic facies: banded, homogeneous and internal pegmatitic. The banded facies is predominant, while the homogeneous variety is rather restricted; the first one is, modally, a granodiorite, the second a monzogranite. The internal pegmatitic facies occurs both as concordant veins and as discordant veins, dikes, and masses, sometimes making up a significant part (20 to $40 \%$ ) of some of the stocks. Main minerals are, in all facies, KF, plagioclase (oligoclase), 
quartz and tourmaline (usually black schorlite, with the beige-greenish and rosy varieties rather common in the larger pegmatitic masses), and garnet and apatite as accessory phases; a large number of secondary minerals is found, in fractures, as replacement rosettes, etc. (white micas, $U$ minerals, etc.). The banded facies (typically, thickness of 3 to $7 \mathrm{~cm}$ ) is constituted by a sequence of bands or layers, each with a lower quartz-enriched level or horizon, an intermediate feldspar-rich level with some tourmaline and a distinctive upper level enriched in tourmaline. These modal variations are frequently accompanied by an increase in grain size (normal pattern with grain-size increase), sometimes with no textural changes (normal equigranular pattern). The bands or layers form continuous sequences of up to several tens of bands, each band maintining its thickness, modal variation, etc.The layering is always complexly folded ("refolding pattern"), as a result of a syn-magmatic deformation episode, therefore not of tectonic origin. The concordant pegmatite veins form as the result of fluid concentration during crystallization. Their relationship with the discordant veins and dikes clearly show that the latter are mainly mobilized portions of the concordant veins, disrupting an existing layering with further concentration in favorable sites, in an overall continuous process of magmatic crystallization and differentiation. Mechanisms that generate the layering in these tourmaline granites cannot be merely controlled by gravitational processes, but are probably the result of double diffusive convection.

It is difficult to reconcile field evidence with the idea that the tourmaline granite magmas were differentiated from less evolved magmas in the Cantareira massif. Geology and topography show no relationships of the Cantareira massif, probably crystallized at greater depths, with the toumaline occurrences, both separated by shear zones. Ages for both are also inconclusive: published figures show 650 or $570 \mathrm{Ma}$ for the tourmaline granites, and $67-630$ or $570 \mathrm{Ma}$ for the porphyritic Cantareira rocks. The origin of the magmas that formed the torumaline granites are still a debated item, awaiting more conclusive isotopic and geochronologic evidence. 


\section{AGRADECIMENTOS}

Gostaria de agradecer a todas as pessoas e instituições que diretamente ou indiretamente colaboraram para a elaboração desta dissertação.

Inicialmente ao Prof. Dr. Horstpeter Ulbrich pela orientação, apoio e acompanhamento durante a evolução do trabalho.

Aos Profs. Sílvio Vlach e Valdecir Janasi, pelo constante incentivo e valiosas sugestǒes.

Ao Gilson, Renato e Marco Aurélio, pelas discussões e troca de informações, e demais colegas da Pós-Graduação Nelson, Nilson, Ricardo, Gandini, Geysa, Rosana, Raquel, Ângela, Sandra, Lucy, Nara, Irena, Annabel, Peter, Jorge, Marcelo, Jaime.

Aos professores do IG-USP, Gergely Szabó, Daniel Atencio, Francisco Alves e Darcy Svisero, pelo convívio durante este tempo de trabalho.

Ao pessoal da laminação, Sr. Cláudio Hopp e toda sua equipe que sempre atenderam prontamente as solicitações mesmo nas situações mais adversas; as bibliotecárias, pela atenção e cuidado; a gráfica do IG, pela confecção da capa e montagem dos volumes e a secretaria do DMP, Marta e Tadeu.

Ao CNPq pela concessão da bolsa de pesquisa (Processo 134348/95-8) e a FAPESP pelo apoio financeiro que viabilizou diversas etapas deste trabalho (Processo 96/0783-8).

Por fim, mas não por último, à $\mathrm{M}^{\mathrm{a}}$. Socorro, minha mãe, e toda minha farnília pelo apoio, compreensão e incentivo. 


\section{CAPÍtulo 1}

\section{INTRODUÇÃo}

\subsection{A TEMÁTICA}

O embasamento do estado de São Paulo apresenta-se dividido em faixas ou domínios de orientação NE, todos eles limitados por extensas zonas de cisalhamento. Cada u.m destes domínios mostra-se constituído por corpos metamórficos característicos e contrastados, ora com predomínio de rochas supracrustais com metamorfismo de grau baixo a médio, ora aparecendo neles gnaisses e migmatitos geralmente ortoderivados. As falhas limitantes, colocando em contato fragmentos litosfériscos aparentemente distintos, devem portanto ter participado ativamente da construção deste particular arranjo estrutural. Adicionalmente, todos estes domínios mostram rochas granitóides de diversas idades, em parte já deformadas ou recristalizadas representado ocorrências mais antigas, mas também outras de aparição mais tardia, identificadas como manifestações da granitogênese brasiliana (650 a $550 \mathrm{Ma}$, eventualmente com idades de até $450 \mathrm{Ma}$ para as ocorrências tardi-orogênicas).

O Domínio São Roque, em particular, limitado por algumas das maiores zonas de cisalhamento (Jundiuvira no limite NW, Taxaquara para SE), é formado por sequências supracrustais, com rochas meta-vulcânicas e de deposição química na base e manifestações detríticas nas partes superiores; rochas com graus metamórfico mais elevados, representadas por mica xistos e gnaisses, afloram tanto no extremo $\mathrm{E}$ como no W da faixa São Roque e são consideradas o embasamento das ocorrências supracrustais. Os vários aspectos da geologia regional e local são discutidos com maior detalhe, e com citação de referências, nos capítulos correspondentes.

O Domínio São Roque encontra-se cortado por grande número de manifestações graníticas, as mais importantes de dimensões batolíticas (São Roque, Itaquí, Cantareira), as menores com dimensões moderadas ou pequenas, mas de grande interesse tanto mineralógico como petrográfico-geoquímico. A região em volta das localidades de Perus e Caieras, à $\mathrm{N}$ da cidade de São Paulo, é a que mostra maior diversidade tipológica de corpos granitóides. O embasamento aqui predominante é de mica-xistos em parte porfiroblásticos, com intercalações de lentes cálcio-silicáticas, ambas litologias por vezes afetadas por metamorfismo de grau mais elevado, particularmente nos contatos com intrusões granitóides. São encontradas na área várias ocorrências de porte menor constituídas por turmalina granito, maciços ou bandados; frequentemente eles também se apresentam como variedades pegmatíticas, seja como parte integrante dos pequenos corpos, seja como veios ou lâminas alongadas, alojadas de maneira independente nas rochas encaixantes. $\mathrm{Na}$ parte $\mathrm{NW}$ desta região, ocorre o maciço granítico Tico-Tico, à duas micas e com granada, enquanto que na região SE são encontradas as manifestações cálcio-alcalinas pertencentes à extremidade ocidental do batólito Cantareira e ao "stock" de Taipas. Os turmalina granitos, em particular, são objetos de exploração comercial de longa data e ficaram conhecidos na literatura brasileira pelas suas caracteristicas 
petrográficas e mineralógicas muito específicas. Eles são, ainda, portadores de uma variada mineralogia de fases acessórias e secundárias, incluindo-se ai minerais uraníferos relativamente raros.

Já existe uma considerável bibliografia sobre estes corpos de turmalina granitos, enfatizando em particular as feições petrográficas e mineralógicas, e em parte também as caracteristicas químicas. Recentemente, estão sendo estudadas as relações destes turmalina granitos com os granitos circundantes por meio de metodologia moderna, procurando-se estabelecer um modelo de evolução magmática em função de dados geoquímicos e de química de mineral (e. g., Wernick et al., 1986; ver Capítulos 2 e 3).

O objetivo da presente dissertação de mestrado é o de destacar principalmente os aspectos geológicos e petrográficos dos granitóides da região de Perus, ainda pouco conhecidos (não existe, por ex., um mapa geológico de detalhe da distribuição dos turmalina granitos, e de suas relações geológicas com corpos vizinhos maiores). Parte-se portanto da realização de um mapa geológico de detalhe, completado com a descrição pormenorizada das diferentes fácies graníticas encontradas na região; particular ênfase é dedicada ao estudo das variações petrográficas existentes nos próprios turmalina granitos.

No Capítulo 1 da dissertação apresenta-se uma introdução geral e uma discussão sobre a metodologia utilizada. O Capítulo 2 aborda aspectos relacionados com o contexto geológico-geotecônico regional. No Capitulo 3 é mostrado o estado da arte da geologia do domínio São Roque; acompanha um mapa regional de compilação, reduzido para a escala 1:100.000, focalizando as regiões em volta da localidade de Perús. O Capítulo 4 trata da geologia local, mostrando os resultados de levantamento de detalhe pelo autor (mapa geológico em escala 1:5.000), junto com uma breve caracterização geológica das unidades mapeadas. No Capitulo 5 são apresentados os aspectos petrográficos dos conjuntos litológicos identificados. Finalmente, no Capítulo 6 são destacadas, de maneira resumida, as principais conclusões.

\subsection{LOCALIZAÇÃO, ACESSO E BASE TOPOGRÁFICA}

A região estudada situa-se à sul da localidade de Vila Perus a aproximadamente 25 km na direção N-NW do centro da cidade de São Paulo. A região é de fácil acesso e constitui em boa parte área urbana, afetada por loteamentos, muitos deles relativamente recentes. As vias de acesso principais são a rodovia Anhanguera, a estrada de Perús e também a avenida Raimundo Pereira de Magalhães (antiga estrada de Campinas), todas elas asfaltadas. Destas estradas partem inúmeros caminhos secundários de terra em boas condições (Figura 1.1). A Foto 1.1 mostra uma visão panorâmica da região, a esquerda (leste) tem-se os morros mais altos, devido aos afloramentos do maciço Cantareira, na porção central dominam as áreas rebaixadas onde tem-se os xistos e as ocorrênias de turmalina granito, e a direita (oeste), ao fundo, se destaca os quartizitos do Pico do Jaraguá. 


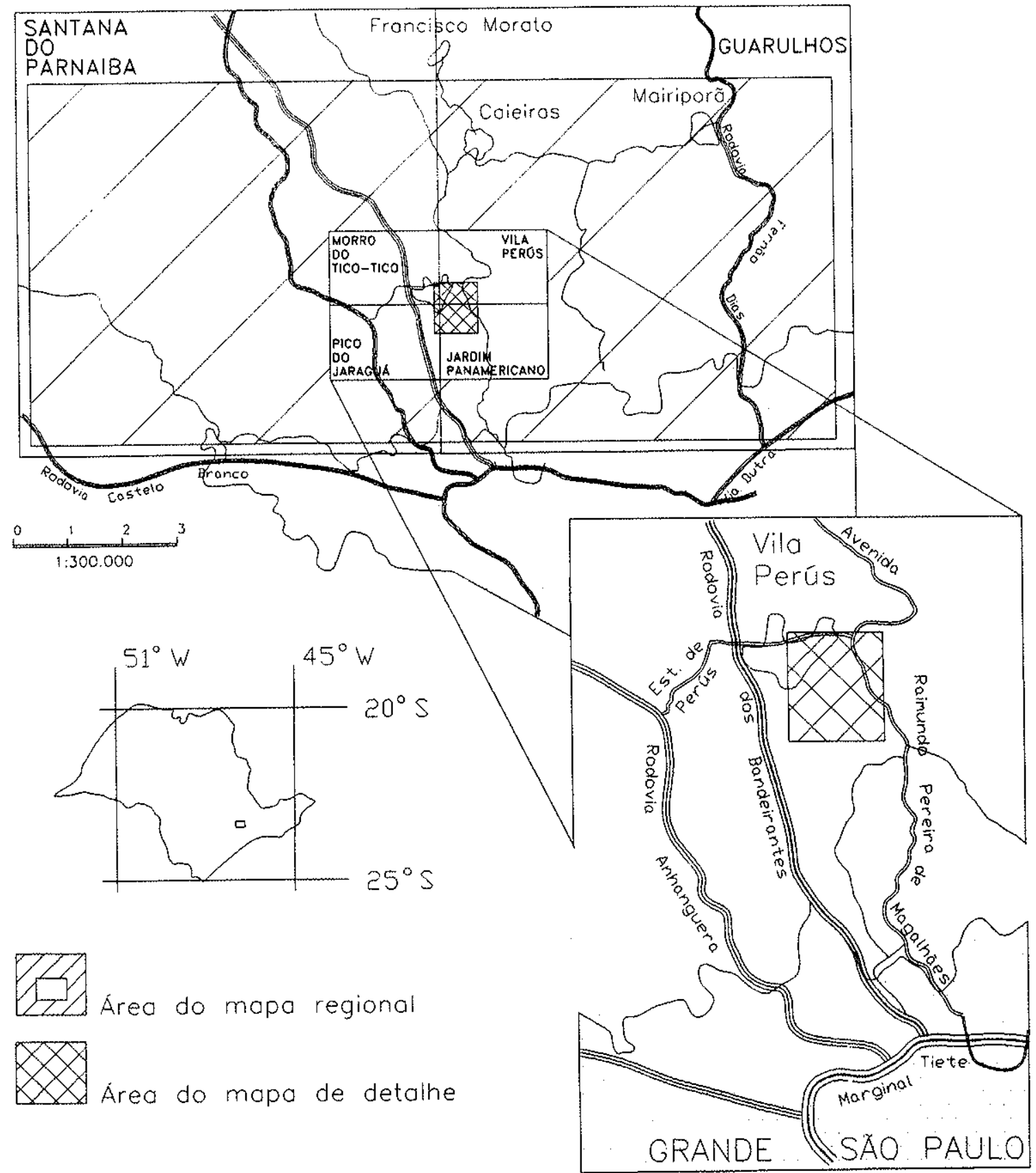

Figura 1.1. A localização da região estudada. O mapa superior mostra os limites do mapa regional de compilação (folhas topográficas Santana do Parnaíba e Guarulhos, em escala 1:50.000) e do mapa de detalhe (folhas Morro do Tico-Tico, Pico de Jaraguá, Perús e Jardim Panamericano, escala 1:10.000). Este último aparece em destaque no mapa inferior juntamente com as vias de acesso. 

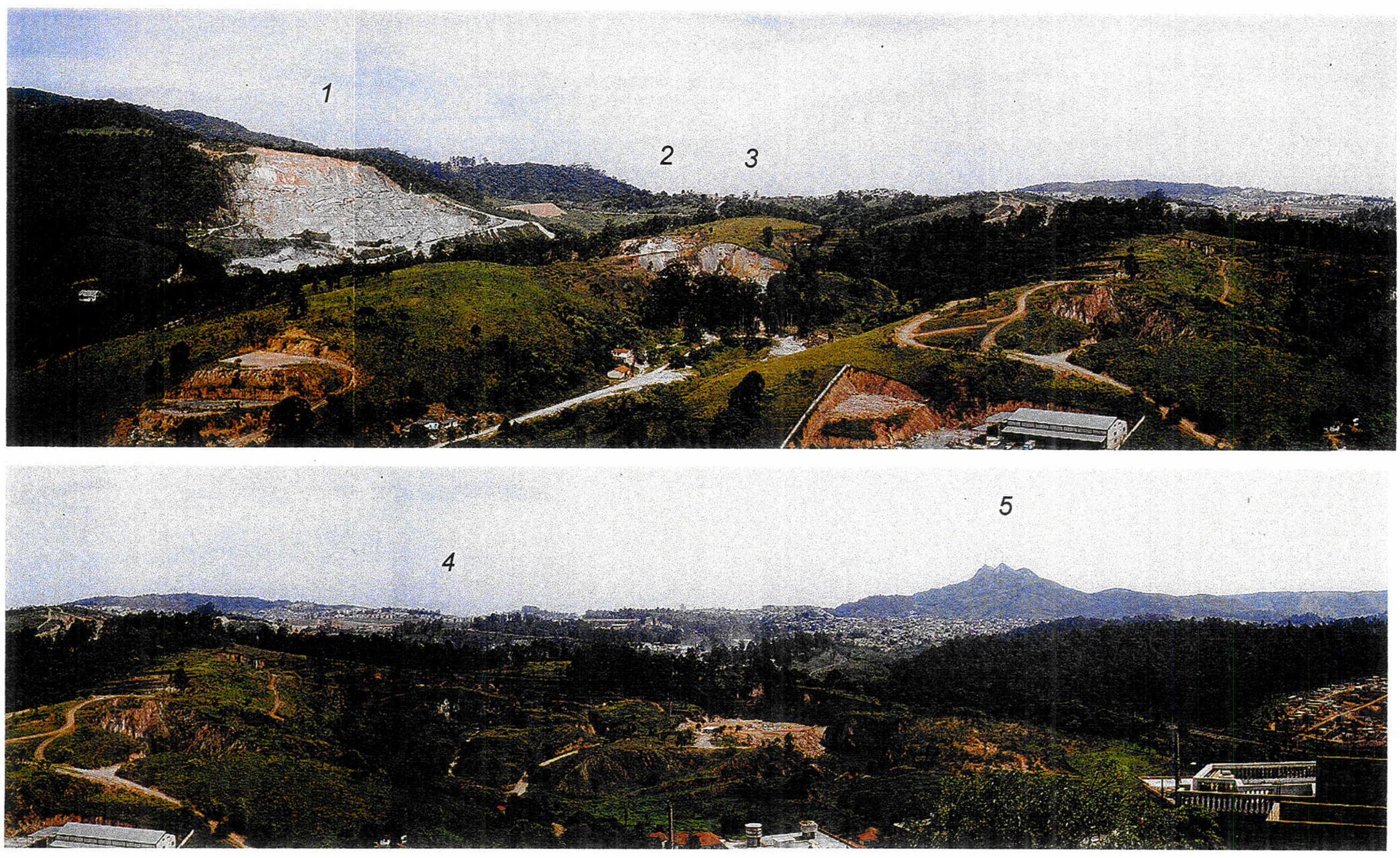

Foto 1.1. Vista panorâmica da região de Perus (visão para sul). Tem-se: 1, pedreira Panorama, no maciço Cantareira; 2 , 3 e 4, as pedreiras Dellantônia, Botuquara e Fiore, respectivamente, de turmalina granito; e 5, o pico do Jaraguá. 
Existem mapas para a região em escala 1:50.000 e 1:10.000. O mapa regional de compilação, em escala $1: 100.000$, foi finalizado utilizando as informações conhecidas sobre a região, com área de aproximadamente $300 \mathrm{~km}^{2}$. Apresenta-se como um polígono retangular, definido grosseiramente pelas cidades de São Paulo, Baruerí, Santana do Parnaíba e Mairiporã. Sua base topográfica constitui-se das folhas Santana do Parnaíba e Guarulhos (ver Capítulo 3). As folhas em escala 1:10.000 Morro do Tico-Tico, Vila Perús, Pico do Jaraguá e Jardim Panamericano (atualizadas até 1994) serviram como base para os trabalhos de mapeamento mais detalhado, com aproximadamente $2 \mathrm{~km}^{2}$ de área e ampliadas para 1:5.000; os resultados são apresentados no Capítulo 4. Os limites do mapa regional e da área mapeada em detalhe estão representados na Figura 1.1.

\subsection{ASPECTOS FISIOGRÁFICOS}

A área estudada está contida na unidade geomorfológica denominada Serrania de São Roque (Ponçano, 1981), que representa a porção do Planalto Atlântico marcado por contínuos processos de denudação, cuja geração relaciona-se com as superficies de aplainamento Itaguá e Japi (Almeida, 1964).

As variaçð̃es geomorfológicas abrangem três formas distintas de relevo. Nas porções leste e sudoeste da área ocorrem as maiores elevações na forma de serras alongadas com até 1100 metros, relacionadas aos maciços Cantareira e Itaqui. Bordejando estes maciços e estendendo-se em todas as direções é encontrado o mar de morros como conjuntos de formas em "meia laranja", com nível de base dos vales a 700 metros de altitude e diferenças de relevo variando entre 100 a 300 metros. É neste domínio que ocorrem os principais corpos graníticos menores Taipas, Morro de Perus, Tico-Tico e as bossas e lentes de turmalina granitos e litotipos associados. Os turmalina granitos, em particular, ocorrem num conjunto de pequenos morrotes com amplitude de relevo menor que 100 metros numa faixa à oeste do maciço Cantareira. No extremo noroeste, ocorrem os morros com serras restritas de maior expressão topográfica que os morros anteriormente citados.

O clima da região é subtropical com períodos de estiagem (abril a setembro) e chuvoso (outubro a março) bem marcados. O principal escoadouro natural é o córrego Perús, da rede de drenagem local, situado 700 metros à oeste das ocorrências estudadas. A vegetação nativa é praticamente inexistente, tendo sido ora totalmente extraída, ora substituida por áreas de reflorestamento.

A área de mapeamento apresenta-se intensamente urbanizada. Os afloramentos de turmalina granitos foram ocupados na década de 60 por empresas de mineração interessadas no feldspato para a industria de cerâmica. As pedreiras ainda em exploração, em número de duas, operam em regime de baixa produção. Recentemente despertou-se o interesse no caulim, para utilização como aditivo à borracha, extraido por alguns moradores da região de grandes buracos, num processo rudimentar de lavra. 


\subsection{METODOLOGIA}

Os turmalina granitos, bem como as manifestações granitóides que afloram nas vizinhanças, apresentam variações internas por vezes consideráveis. Elas podem ser registradas por meio de descrições pormenorizadas e mapeamento de detalhe ou semidetalhe, identificando as suas distintas fácies petrográficas. Cada um destes litotipos representa um aspecto particular dentro da história de evolução e/ou colocação destes maciços (ver, por ex., Ulbrich, 1984). O mapa resultante, junto com as descrições das variações encontradas, constituem o fundamento para embasar discussões e interpretações petrogenéticas, estruturais e geoquímicas. Os objetivos do trabalho de campo foram, então, os da identificação dos diversos litotipos, reconhecimento de suas extensões e das relações existentes entre eles. Os trabalhos de laboratório concentraram-se na descrição estrutural, petrográfica e mineralógica das amostras coletadas. As interpretaçð̃es finais, por estar baseadas em dados restritos, enfatizam principalmente os aspectos ligados ao posicionamento dos corpos menores e à origem de estruturas e texturas magmáticas.

\subsubsection{Andamento dos trabalhos}

Os trabalhos de campo iniciaram-se no segundo semestre de 1995 com visitas às varias pedreiras da região. Durante o ano de 1996 foram realizados perfis ao longo das principais vias de acesso e das estradas secundarias, bem como em torno dos corpos de turmalina granitos, visando inicialmente ao reconhecimento dos contatos geológicos, posteriormente refinados ao proceder-se ao adensamento dos pontos. As observações foram também estendidas aos "stocks" de Taipas e Tico-Tico e ao maciço Cantareira. Foi montada uma coleção de rochas representativas das diferentes faciologias reconhecidas.

Ainda no segundo semestre de 1995, como suporte para os trabalhos de campo, foi realizada a fotointerpretação de três levantamentos aerofotogramétricos na região de Perús, escala 1:30.000, realizados em 1950, 1964 e 1980, visando principalmente a reconstituição do desenvolvimento das lavras nos turmalina granitos e a confecção de bases topográficas.

A parte laboratorial do trabalho iniciou-se no segundo semestre de 1996 com o estudo e descrição das seções delgadas e a contagem das modas, com sua representação em diagramas apropriados; estas primeiras observações de laboratório, juntamente com os dados de campo, identificaram os maiores problemas a serem resolvidos.

\subsubsection{Tratamento dos dados topográficos}

Para esta dissertação os mapas geológicos regional e de detalhe foram confeccionados através da digitalização das folhas topográficas apropriadas, em parte atualizadas até 1994, utilizando o software AutoCAD-Release12. O mapa regional compilado foi construído utilizando as folhas do IBGE Santana do Parnaíba (SF.23-Y-CIII-3 / MI-2767-3) e Guarulhos (SF.23-Y-C-III-4 / MI-2767-4), ambas na escala 1:50.000. Os trabalhos de detalhe foram realizados por meio das folhas Morro do Tico-Tico (SF-23Y-C-III-3-SE-B), Pico do Jaraguá (SF-23-Y-C-III-3-SE-D), Perús (SF-23-Y-C-III-4-SO-A), e Jardim Panamericano (SF-23-Y-C-III-4-SO-C), todas na escala 1:10.000, da EMPLASA. 
Optou-se por este processo de tratamento das bases topográficas utilizadas durante o mapeamento de detalhe e a fase de confecção do mapa regional, devido a inexistência de folhas na escala adequada ao trabalho de campo (1:5.000) e de compilação (1:100.000) e por estas áreas de interesse estarem sempre localizadas na confluência de folhas distintas.

Na mesa digitalizadora, após a calibração utilizando coordenadas UTN, foram traçados os principais elementos topográficos de cada folha, tais como curvas de nível, redes de drenagem, vias de acesso e obras de cultura, em layers distintos, compondo no final a base a ser trabalhada. O mapa de compilação foi realizado pela inclusão de informações geológicas disponíveis na literatura (unidades mapeadas, contatos, estruturas regionais mais importantes, fotolineamentos), que quase sempre se mostravam em escala distinta da base topográfica confeccionada. O mapa regional obtido a partir das duas folhas do IBGE, em escala 1:50.000, foi impresso em escala 1:100.000 e o mapa de detalhe, construido por meio das quatro folhas da EMPLASA em escala 1:10.000, foi impresso na escala 1:5.000.

\subsubsection{Análises petrográficas}

Para o estudo mineralógico e textural das rochas foram confeccionadas 70 lâminas delgadas, analisadas sob luz transmitida. Foram ainda utilizadas cerca de 10 seçð̃es delgadas polidas, para a identificação e estudo textural dos minerais opacos através de luz refletida. Para contagem modal foram adicionalmente cortadas 40 fatias de rochas porfiríticas de granulação mais grossa e/ou estruturalmente complexas, representativas dos maciços Cantareira, Taipas e Tico-Tico.

A contagem modal em lâminas delgadas é feita ao microscópio com auxilio de vernier e contador de pontos, com intervalos que variam entre 0,1 e $0,5 \mathrm{~mm}$, conforme a granulação da rocha. Foi contado um número mínimo de 1200 pontos por lâmina, varrendo em media $80 \%$ da sua área útil.

A contagem das fatias, após tingimento com solução de cobaltinitrito de sódio, cobriu áreas entre 170 a $300 \mathrm{~cm}^{2}$, sempre dez vezes maior que a área do maior grão da fatia. A contagem (em torno de 1300 a 1500 pontos) foi realizada nos nós de um retículo transparente de espaçamento regular, com distância variável de acordo com a granulação da rocha, colocado sobre a fatia. A identificação do feldspato potássico em fatias de rocha é facilitada pela cor amarela, obtida por tingimento com cobaltinitrito de sódio enquanto os grãos de plagioclásio se mantém com coloração esbranquiçada. Esta contagem permite, assim, obter valores representativos das proporções de feldspato potássico, plagioclásio, quartzo e do conjunto de minerais máficos e acessórios. Por sua vez, os teores individuais dos vários minerais máficos foram determinados por contagem modal em lâmina.

A solução de tingimento é obtida através da dissolução total de $19,64 \mathrm{~g}$ do sal cobaltinitrito de sódio, num béquer de $250 \mathrm{ml}$, em $5 \mathrm{ml}$ de ácido acético seguida da diluição com água destilada até completar um volume final de $200 \mathrm{ml}$ de solução. $\mathrm{O}$ volume é suficiente para coloração de um conjunto de 10 amostras. A solução é aplicada sobre a superficie da fatia, previamente tratada como exposto a seguir: 
$1^{\circ}$ - Num recipiente plástico contendo solução de ácido fluorídrico concentrado são mergulhadas as fatias, durante aproximadamente 50 segundos.

$2^{\circ}$ - Numa segunda bandeja com água pura as fatias são lavadas, para remoção do excesso de HF, e em seguida secadas preferencialmente com ar comprimido.

$3^{\circ}$ - O tingimento é realizado com a imersão das fatias em uma terceira bandeja plástica contendo a solução preparada, durante 50 segundos.

$4^{\circ}$ - As fatias são lavadas a seguir em água corrente, para retirada do excesso de solução.

Após secagem ao natural é recomendável a pulverização da superfície das fatias com spray acrílico para impermeabilização e preservação das películas de tingimento. 


\section{CAPítulo 2}

\section{O CONTEXTO GEOLÓGICO-GEOTECTÔNICO REGIONAL}

\subsection{ARCABOUÇO GEOTECTÔNICO}

Os granitóides localizados na região de Perus e vizinhanças, no estado de São Paulo, aparecem invadindo rochas metassedimentares do Grupo São Roque, que constituem uma faixa dobrada com deformações e/ou retrabalhamento de rochas mais antigas, juntamente com intrusões graníticas, todas devidas à atuação do ciclo Brasiliano (definido por conjuntos de rochas geradas e/ou deformadas entre 700 e $450 \mathrm{Ma}$ como identificado por datações $\mathrm{Rb} / \mathrm{Sr}$ e K/Ar; Almeida et al., 1971; para bibliografia abrangente sobre o Brasiliano, ver Hasui et al., 1978a; Trompette, 1994). Estas rochas metamórficas, limitadas à $\mathrm{N}$ pela zona de cisalhamento de Jundiuvira e à $\mathrm{S}$ pela de Taxaquara, são parte integrante de uma unidade geológico-geotectônica maior, o cinturão de dobramento Ribeira, importante constituente do embasamento cristalino do estado de São Paulo e dos estados vizinhos. Este cinturão, que contorna no limite com Minas Gerais a parte sul da cunha ou maciço de Guaxupé, desvia-se a seguir para fornecer o limite $E$ do craton do São Francisco.

As relações entre o cinturão Ribeira e as outras grandes unidades geológicogeotectônicas da região SE brasileira são resumidamente apresentadas no parágrafo seguinte.

A plataforma sul-americana, com as suas várias coberturas sedimentares, aparece expressa na região do SE do Brasil pelo chamado escudo atlântico (Almeida et al., 1976; Schobbenhaus et al., 1984). Como os seus elementos constitutivos mais importantes, são citados o craton do São Francisco e os cinturões de dobramento que o circundam. $O$ craton do São Franscico é uma área estável de complexa história, que mostra núcleos arqueanos (idades superiores a $3 \mathrm{Ga}$ ), retrabalhados por eventos ou ciclos tectono-térmicos mais novos, tais como o de Jequié $(2,6-2,7 \mathrm{Ga})$ e o Transamazónico $(\sim 2,0 \mathrm{Ga})$, registrando-se ainda a atuação final do ciclo Brasiliano (700-450 Ma). A extremidade meridional do craton mostra-se mais estreita, bordejada por um conjunto complexo de faixas dobradas de idade brasiliana, em parte apresentando retrabalhamento de crosta mais antiga, mas também com contribuições juvenis. Na sua margem leste, aparece para $\mathrm{N}$ a faixa de dobramento Araçuaí (Almeida, 1976, 1977; também Almeida et al., 1978, citado em Schobbenhaus et al., 1984), com direção e estruturas predominantes N-S. A partir do meridiano $20^{\circ} \mathrm{S}$, é encontrada a extremidade setentrional da faixa dobrada ou cinturão Ribeira (Almeida et al., 1973; ver Schobbenhaus et al., 1984), nesta região com estruturas dominantes $\mathrm{N}-\mathrm{S}$, que infletem para SW à altura do meridiano $22^{\circ} \mathrm{S}$, adaptando-se desta maneira à porção terminal do craton. $O$ contorno ocidental cratónico é limitado pelo cinturão Brasília, com direção e estruturas predominantes $\mathrm{N}-\mathrm{S}$, conectado para $\mathrm{S}$ com o cinturão Ribeira. Na junção destes dois cinturões, aparece na parte meridional a cunha do 
maciço mediano ou complexo de Guaxupé, de forma triangular, com vértice apontando para E. O cinturão Ribeira, por sua vez, continua mais para o Sul, sendo o constituinte principal dos embasamentos cristalinos dos estados do $S$ e SE brasileiros (São Paulo, Paraná, Santa Catarina, Rio Grande do Sul), com algumas importantes intercalações mais antigas, anteriormente tidas como representativas de "maciços medianos" (e.g., o de Joinville; o chamado Complexo Costeiro, no litoral de São Paulo, Paraná e Santa Catarina), hoje consideradas parte integrante de regiões cratónicas (cratons Luis Alves e Rio de la Plata; e.g., Schobbenhaus et al., 1984).

A seguir, são discutidos, em sequência de apresentação na literatura específica, os três modelos geotectônicos mais relevantes para a compreensão do contexto geológicogeotectônico dos granitóides estudados.

\subsubsection{O modelo geossinclinal de Ebert (1968)}

A proposta de Ebert, acompanhada de mapa já apresentado em 1965, está baseada em modelos geológico-geotectônicos corriqueiramente utilizados por pesquisadores europeos, particularmente os de Hans Stille (e.g., Loczy \& Ladeira, 1980). Estes geólogos identificavam um modelo "alpinotipo" de deformação, com aparição de faixas dobradas duplas situadas entre duas áreas estáveis (geralmente continentais, mas que poderiam também ser oceânicas, na concepção de Stille). A compressão era realizada contra um antepais ("foreland"); neste, as coberturas sedimentares eventualmente presentes registram pouca ou nenhuma deformação ou influência de atividade metamórfica. As duas faixas dobradas diferenciavam-se pelo tipo de sedimentação que recebiam, e ainda pela presença (ou ausência) de atividade ígnea e a intensidade da deformação e do metamorfismo. A faixa chamada de "externides", adjacente ao antepais, era identificada pela ausência de sedimentos imaturos, a falta de atividade intrusiva, e um metamorfismo fraco (fácies xistos verdes, ou menor). A segunda faixa, a dos "internides", paralela à dos "externides" e mais afastada do antepais, caracterizava-se pela sedimentação de materiais mais imaturos (grauvaques, etc.) e presença de vulcanismo, e um metamorfismo mais intenso (facies anfibolito ou até granulito) acompanhado de invasões graníticas ("granitização" mais marcada). Na teoria geossinclinal clássica (e.g., Kay, 1951; Krumbein \& Sloss, 1951; Aubouin, 1965; Loczy \& Ladeira, 1980), os "externides" e "internides" se correspondem, pelo menos em parte, aos conceitos de "miogeossinclinal" e "eugeossinclinal", respectivamente.

Foi também Stille (e.g., Stille, 1958) o pesquisador que comprovou a presença, nos vários continentes, do que chamou de evento "assíntico" de orogenia, deformação e metamorfismo, hoje caracterizado como evento Brasiliano na América do Sul, de Panafricano na África, etc. O nome "assintíco" deriva da discordância encontrada no distrito de Assynt, na Escócia setentrional, que separa os arenitos Torridonian (de idade précambriana incerta), levemente deformados, dos sedimentos calcário-pelíticos não deformados suprajacentes, com fauna de Olenellus do Cambriano inferior (Stille, 1958); esta fase orogênica se localizaria, portanto, no Precambriano superior, provavelmente perto do limite com o Cambriano (> $500 \mathrm{Ma}$ ).

Utilizando estes modelos geotectônicos, Ebert interpretava suas observações realizadas nas faixas dobradas de São Paulo e Minas Gerais, com forte ênfase em dados 
geológicos e petrográficos (faciologia das rochas metamórficas) (Figura 2.1). O antepais ("foreland") de Ebert aparece representado pela "bacia do rio São Francisco" (com cobertura de rochas sedimentares a metassedimentares anquimetamórficas) e a "zona do Espinhaço" (com as Séries Minas e Itacolomi, mostrando grau metamórfico da fácies xistos verdes, subfácies da clorita). No limite oriental do antepais aparece a faixa orogênica "assíntica" dos Paraibides (= neo-precambriana, idade provável da ordem de $550 \mathrm{Ma}$; ver Ebert, 1968), de percurso $\mathrm{N}$ a NE e que continua com direção $\mathrm{SW}$, após o limite inferior do antepais, passando pelos estados de São Paulo, Paraná e Santa Catarina. Para W aparece uma inflexão ("virgação") da faixa orogênica, contornando a extremidade meridional do antepais, constituindo uma segunda faixa com tendência final NW, a dos Araxaides. Atraves do grau metamórfico, Ebert pôde identificar também o cinturão dos externides de baixo grau metamórfico, adjacente ao antepais, com paragênese minerais metamórficas da fácies xistos verdes (subfácies de clorita e biotita) e anfibolito (subfácies com estaurolita); que forma a parte ocidental dos Paraibides, proximal ao antepais. As unidades mais importantes dos externides seriam os Grupos São João del Rei, com rochas da fácies xistos verdes, em Minas Gerais, e o Grupo Açungui em São Paulo, também com paragêneses da facies xistos verdes e supostamente pobre em feldspatos. O cinturão dos internides, com grau metamórfico maior, distal ao antepais, mostra paragêneses da fácies anfibolito e indicações de intensa atividade granítica (intrusões, migmatitos, "granitizações")'. O constituente estratigráfico mais importante dos internides estaria constituído pelo Grupo Paraiba, que mostraria principalmente paragnaisses (em parte, migmatíticos), micaxistos e escassos granulitos, provavelmente derivados de sedimentos eugeossinclinais tais como arcósios e grauvaques; subordinadamente, encontram-se escarnitos, quartzitos e ortognaisses. Em Minas Gerais, o Grupo Andrelândia seria uma unidade importante dos internides, constituido por mica-xistos mais pobres em feldspatos e quartzitos, possivelmente representando já uma transição para sedimentos de miogeossinclinais. Claramente anômala é a faixa São Roque (mostrando rochas da fácies xistos verdes, com filitos, quartzitos e metacalcários predominantes, mineralogicamente pobres em feldspatos) por registrar no seu interior a presença de vários corpos graníticos, embora seja considerada como um segmento dos externides; era identificada naquela época como equivalente do Grupo Açungui.

Desvinculadas destas faixas dobradas "assinticas", aparecem regiões com rochas da alta fácies anfibolito e com intercalações de lentes charnoquíticas; entre estas, destacase a "cunha" de Guaxupé, já reconhecida como tal no mapa de Ebert (ver Figura 2.1).

\subsubsection{O modelo de Almeida, Hasui e coautores (1966-1981): os geossinclíneos e as grandes estruturas brasilianas no SE brasileiro}

A partir de 1966, F.F.M. de Almeida vêm desenvolvendo, individualmente ou com outros autores, um modelo de compartimentação tectônica e de evolução da chamada Plataforma Sulamericana, num primeiro momento identificando as principais unidades geológico-geotectônicas, refinando a seguir estes modelos e definindo as várias fases evolutivas, modelo também adotado em grandes linhas pela maioria dos geopesquisadores brasileiros (Almeida, 1966, 1967, 1969, 1977; ver também Almeida et al., 1973, 1976, 1981; Hasui et al., 1978a; Wernick et al., 1978; Schobbenhaus et al., 1984, e bibliografia alí citada). 


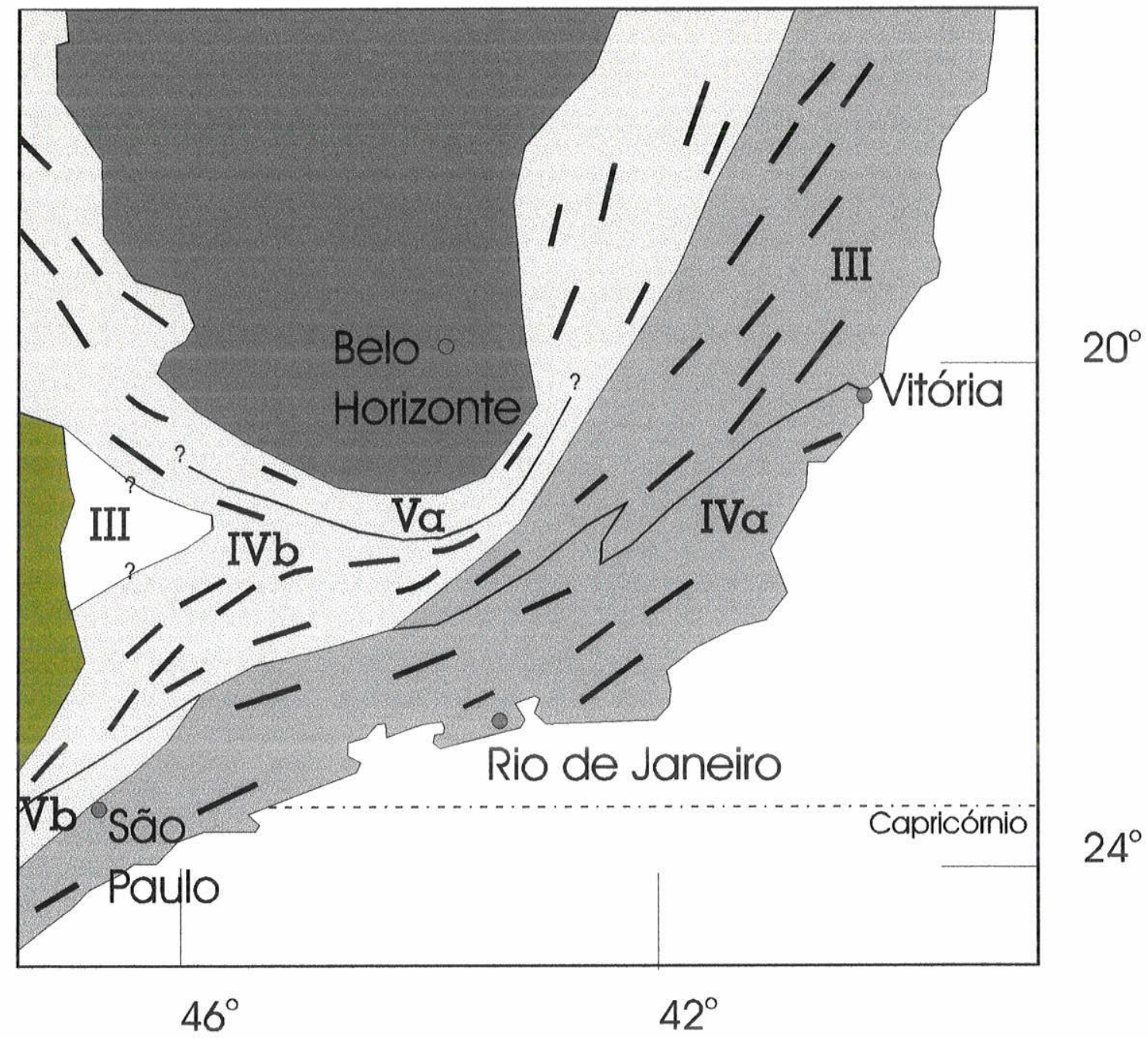

\begin{tabular}{|l|ll} 
Traço estrutural & III- & $\begin{array}{l}\text { Zona de fácles granulítica } \\
\text { Bacia do Paraná }\end{array}$ \\
Internides & IVa- $\begin{array}{l}\text { Zona de fácies anfibolítica } \\
\text { (subfácies com silimanita) }\end{array}$ \\
Externides & IVb- $\begin{array}{l}\text { Zona de fácies anfibolítica } \\
\text { (com subfácies estaurolita e cianita) }\end{array}$ \\
Antepais & Va- $\begin{array}{l}\text { Zona de fácies xisto verde } \\
\text { (subfácies com biotita e clorita) }\end{array}$ \\
\hline
\end{tabular}

Figura 2.1. O modelo geossinclinal de Ebert (1968). Para maiores detalhes, ver texto. 
$\mathrm{O}$ quadro geológico-geotectônico no $\mathrm{SE}$ brasileiro se inicia com a definição de uma unidade cratônica antiga, a do craton de São Francisco, envolvido por extensa e complexa faixa de dobramento, coletivamente identificada como "Região de Dobramento do SE" brasileiro (ou "cinturão dobrado Ribeira"), que em termos geotectônicos é equivalente, no NE do território nacional, à "Região de Dobramento NE" (e.g., Hasui et al., 1978a; Wernick et al., 1978). O craton de São Francisco mostra bordas ainda mal definidas, em virtude de coberturas posteriores e o retrabalhamento de suas margens, à época brasiliana, ocultando-se com isto os seus limites reais. Nas regiões de dobramento são identificadas duas unidades estruturais diferentes, uma constituída pelas faixas de dobramento, a outra pelos chamados "maciços medianos". As faixas de dobramento, em concordância com as ídeais previamente difundidas por Ebert (e.g., Ebert, 1968), mostrariam uma parte externa, com metamorfismo mais marcado e maior intensidade de atividade ígnea (equivalente aos "internides", ver item anterior), e uma proximal ao craton (os "externides"), com metamorfismo pouco intenso (fácies xistos verdes) e que em parte afeta também as coberturas cratónicas. Os maciços medianos, por sua vez, estariam representados por porções da crosta siálica mais antiga, retrabalhada durante o evento brasiliano, limitados por falhas transcorrentes de direções concordantes com as principais atitudes estruturais reproduzidas nos cinturões dobradas (e.g., NE-SW na região do SE brasileiro).

As regiões de dobramento são, no SE brasileiro e nas áreas de interesse do presente trabalho, principalmente as faixas Apiaí e São Roque, com estruturas orientadas no sentido NE-SW, limitadas à N-NE pelo maciço mediano Guaxupé e, à S-SE pelo maciço mediano Joinville. O craton de São Francisco, por sua vez, aparece rodeado, para W, pelo cinturão dobrado Brasília e, para $\mathrm{E}$, pelo cinturão Araçuaí (Figura 2.2).

A atividade brasiliana nesta região é definida da seguinte maneira: início por volta de 1,0 a $0,7 \mathrm{Ga}$, com aparição de bacias controladas por falhamento profundo, sedimentação e alguma atividade vulcânica básica, seguida de etapa intemediária $(0,7-0,6$ $\mathrm{Ga}$, com metamorfismo regional, deformação polifásica, magmatismo ácido e migmatização nas regiões mais profundas, com etapa final (600-450 Ma) acompanhada de soerguimento, intrusão de corpos graníticos pós-tectônicos, ativação (reativação?) de falhas transcorrentes e geração de "antefossas" e "intrafossas" com sedimentação molássica. Os blocos mais altos da regiáo foram afetados, durante todos estes periodos, por metamorfismo adicional, migmatização, intrusões graníticas e, em parte, também registraram sedimentação; são fragmentos mais soerguidos do embasamento prébrasiliano, de idades proterozóicas ou até, predominantemente, arquenas, que hoje constituiriam os maciços medianos.

A sedimentação brasiliana pode ser mais facilmente reconhecida nas faixas marginais ("externides"), menos deformadas e mostrando metamorfismo de baixo grau. A sequência basal, sem conglomerados basais, é tipicamente clástico-química (com quartzitos, metacalcários, etc.) com alguma participação de derrames básicos (anfibolitos, clorita xistos), seguida por uma sequência clástica de tipo flyschóide (metarenitos e metarritmitos), sem participação de derrames básicos. Em algumas regiōes, são observados pacotes por vezes espessos de rochas carbonáticas, mais antigos que as rochas clásticas flyschóides. As faixas de dobramento internas estão representadas principalmente por mica xistos e gnaisses, intensamente deformadas, deslocadas por 
falhamentos e migmatizadas; fica assim dificultada a reconstrução de colunas estratigráficas.

São reconhecidas várias fases no magmatismo brasiliano, predominantemente granítico. A fase inicial, de composição basáltica, é evidentemente contemporânea à sedimentação, aparecendo apenas em algumas regiões específicas (e.g., basaltos na forma de "pillow-lavas" na região de Pirapora, SP). Muito mais importante é o magmatismo sintectônico, com aparição de corpos dos mais variados tamanhos, batolíticos os maiores, com características geoquímicas-mineralógicas cálcio-alcalinas e com predomínio de rochas granitóides; em parte, constituem corpos sin-tectônicos gnaissificados. Numa fase posterior, tardi-tectônica, aparecem corpos menores, mais circunscritos, cujas características petrográfico-estruturais são, em parte, similares às dos corpos sintectônicos.
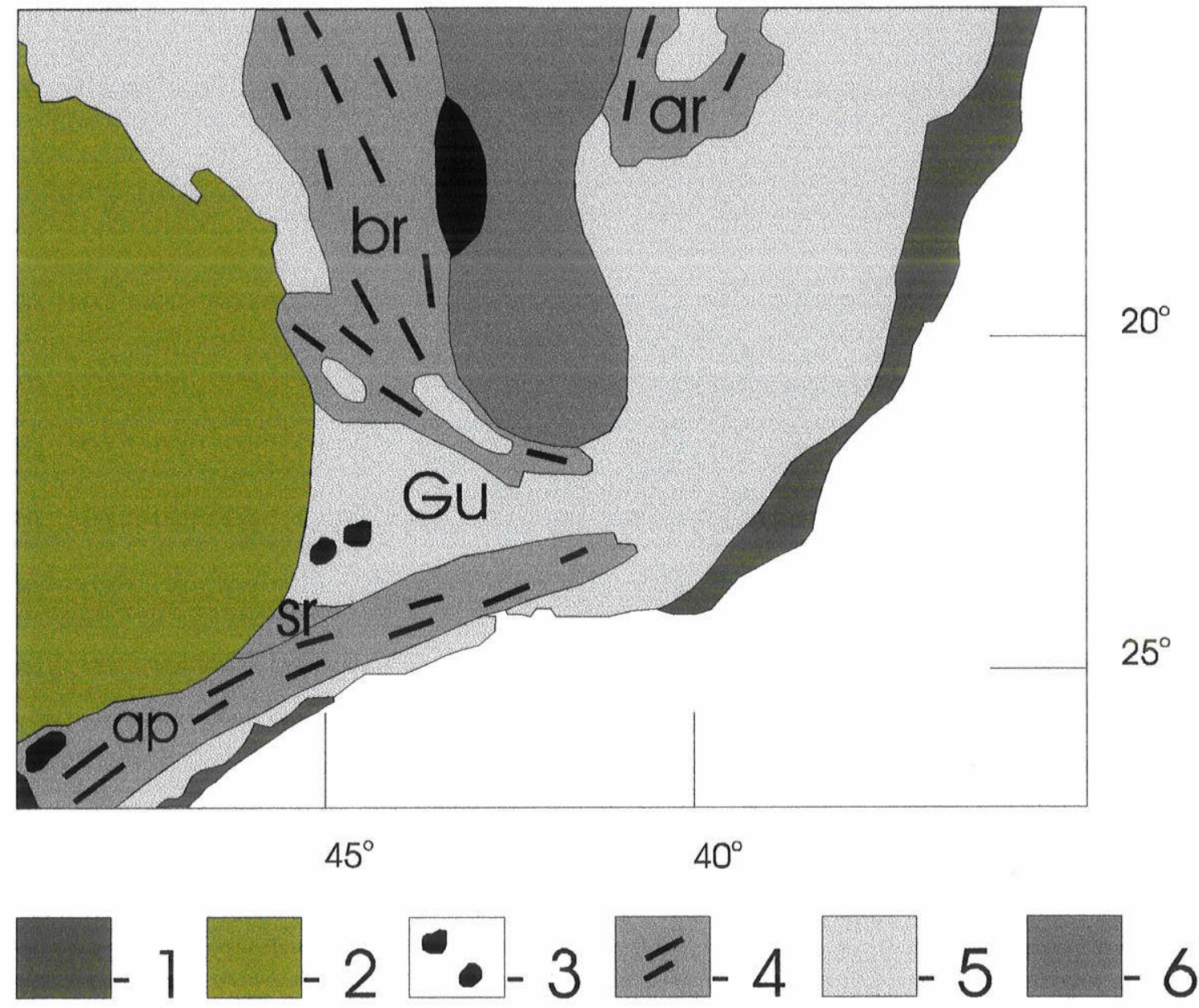

Figura 2.2. Mapa geotectônico para a região sudeste segundo Hasui, 1978. O núcleo crustal mais estável, o craton do São Francisco (6), aparece bordejado pelo embasamento remobilizado (5) e pelas faixas de dobramentos (4) Araçuai - ar, Brasília -br, Apiaí -ap e São Roque -sr, todas de idade brasiliana, com as antefossas e intrafossas molássicas (3). São representados ainda o maciço mediano de Guaxupé ( $\mathrm{Gu})$, a bacia do Paraná (2) e a cobertura fanerozóicas da margem continental (1). 
Uma última fase magmática, pós-tectônica, também predominantemente caracterizada por diversos granitóides, com localização em parte determinada por falhas e aparição de auréolas de contato nas rochas encaixantes. A literatura da época, indica que as manifestações intrusivas mais importantes localizam-se, de preferência, em geanticlinais e nos maciços medianos, enquanto que as próprias faixas de dobramento registrariam a presença de corpos intrusivos tipicamente menores (ver, por ex., Wernick et al, 1978).

2.1.3. A Faixa Alto Rio Grande e nappes de empurrão: sedimentação, defornação e intrusões em regiões remobilizadas de borda cratônica (Campos Neto, Hasei e colaboradores, 1984-1991)

O modelo sugerido por Campos Neto, Basei e colaboradores (e.g., Campos Neto, 1985, 1991; Campos Neto et al., 1984, 1990; Vasconcellos, 1988; Peloggia. 1990; Perrotta, 1990) baseia-se em vários trabalhos de mapeamento, em escala 1:50.000 ou de maior detalhe, realizados durante fins da década de 70 e na de 80 e que foram acrescidos de dados de laboratório tanto geoquímico-mineralógicos como isotópico-geocronológicos.

A interpretação da região de dobramento do SE brasileiro, em termos resumidos, é a seguinte. Reconhece-se uma faixa de dobramentos alongada, a Faixa Alto Rio Grande, que foi inicialmente proposta por Y. Hasui em 1982 para englobar as rochas deformadas atribuídas aos Grupos Andrelândia e São João del Rei, na margem meridional do craton de São Francisco. Ela aparece exposta tanto no embasamento cristalino de São Paulo, com direção geral N-S na região de Amparo, para tomar, mais para $\mathrm{N}$, uma direção $\mathrm{E}-\mathrm{W}$ a ENE-WSW em Minas Gerais (regiões de Ouro Fino, Pouso Alegre e Heliodora). Aparece integrada por rochas altamente deformadas do Arqueano-Paleoproterozóico, por sua vez recorbertas por coberturas sedimentares, hoje metamorfoseadas e tectonicamente transportadas, representando pelo pelo menos três ciclos de sedimentação, com idade limite para a sedimentação da ordem de $1400 \mathrm{Ma}$. A Faixa Alto Rio Grande foi recoberta, por efeitos da tectônica brasiliana, pela complexa e extensa Nappe de empurrão SocorroGuaxupé, colocada por volta de 600-550 Ma atrás (ver distribuição das unidades na Figura 2.3).

Na porção ocidental da Faixa alto Rio Grande são reconhecidas, como as unidades mais antigas, arqueanas a proterozóicas inferiores, os complexos Amparo (gnaisses migmatíticos tonalíticos a graníticos) e São Gonçalo do Sapucaí (ortognaisses tonalíticosgranodioríticos), os Gnaisses migmatíticos graníticos Heliodora e a Associação MáficaUltramáfica de Arcadas (xistos máficos e anfibolitos máficos a ultramáficos).

As três unidades sedimentares do Mesoproterozóico são formadas por uma sequência plataformal transgressiva basal com quartzitos, metapelitos e rochas clásticoquímicas e vulcanoclásticas (equivalentes ao Grupo Carrancas, da região de São Tomé das Letras). A esta, segue uma sequência intermediária grauváquica, constituída por gnaisses cinzentos e cálcio-silicáticos e intercalações de anfibolitos (com geoquímica que sugere derivação de rochas-fontes vulcânicas intermediárias-ácidas; em parte, equivalem à rochas do Grupo Andrelândia). A unidade superior é uma sequência plataformal progradacional composta por gnaisses quartzosos e quartzitos com mica, derivados de pacotes pelíticopsamíticos, que constitue o Grupo Itapira. O empilhamento e colocação final destes pacotes sedimentares deve ter-se dado, com transporte em direção ao craton do São 


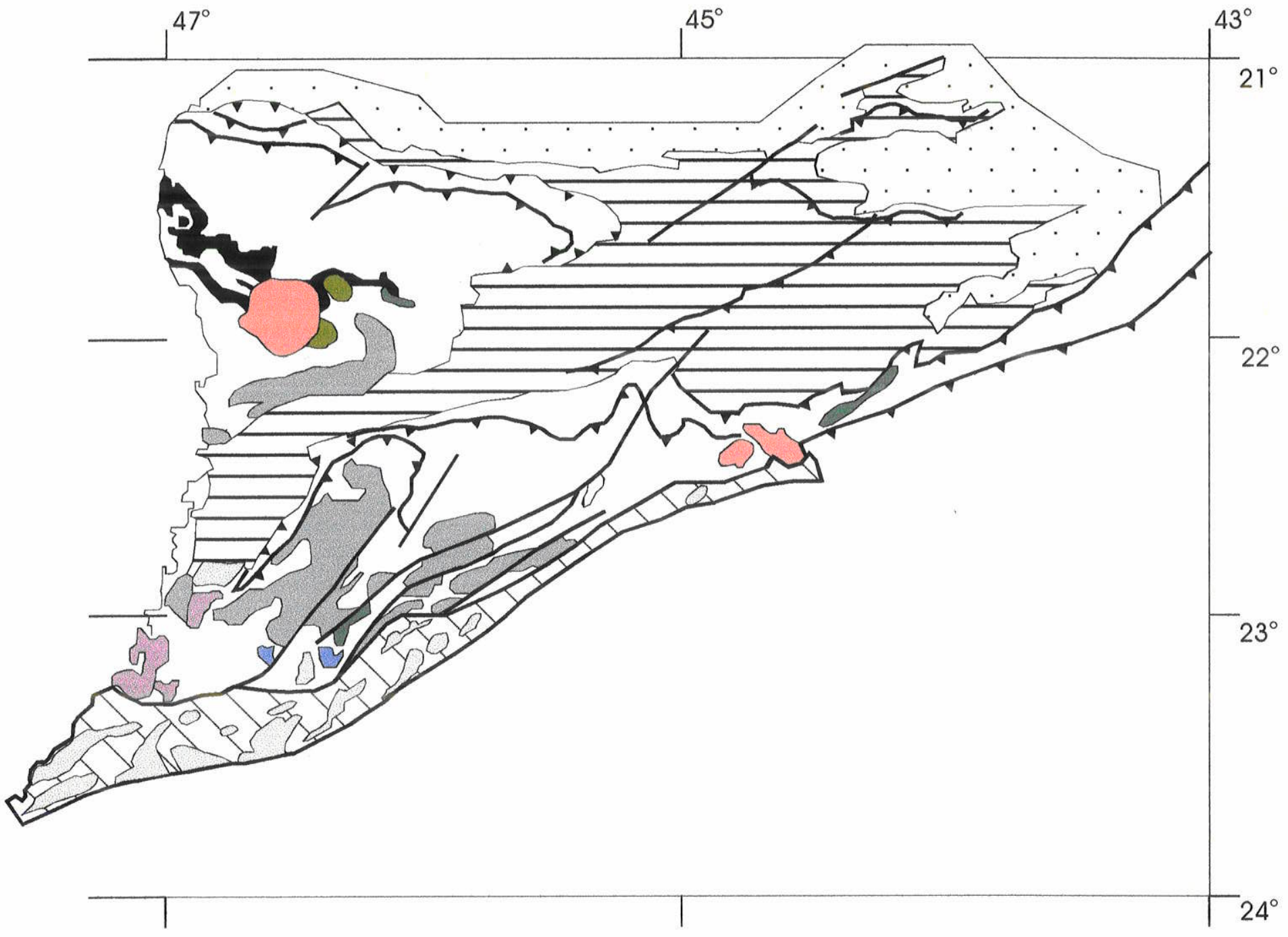

Maciços Alcalinos

Nappe de empurrão Socorro-Guaxupé

Domínio São Roque

Suites magmáticas brasilianas

Sienitos tardios

Suite granítica rósea ou rapakivi

Maciço monzodiorítico-monzonítićo

Granitóides porfiróides do tipo I Caledoniano

Suite granítica peraluminosa a granada

Suite cálcio-alcalina potássica

Suite mangerítica

Faixa Alto Rio Grande

Borda de retrabalhamento do craton

Figura 2.3. A Nappe de Empurrão Socorro-Guaxupé e a Faixa Alto Rio Grande (modificado de Campos Neto et. al. (1989) e Vasconcelos et. al. (1988), segundo haddad (1994)). 
Francisco, no final do Proterozóico Médio ou início do Neoproterozóico. Rochas intrusivas aparecem como escassos corpos graníticos tabulares de espessura limitada. São admitidas várias fases de deformação e três eventos metamórficos de diferentes idades e intensidades.

A Nappe de empurrão Socorro-Guaxupé constitue uma das maiores unidades geotectônicas do embasamento de São Paulo, colocando-se em ambos os lados da Faixa alto Rio Grande (Figura 2.3). A importância de empurrões na construção dos compartimentos tectônicos desta região já foi indicada em publicações anteriores (e.g., Ebert, 1968), mas a configuração real desta estrutura só foi reconhecida nos últimos anos, adicionando-se com isto um componente significativo para futuras modelagens. Na parte basal da Nappe são encontrados granada granulitos enderbítico-charnoquíticos (idades superiores a $2 \mathrm{Ga}$ ), em parte migmatizados, granulitos gnáissicos e migmatitos e granitognaisses vários. No topo passa-se para rochas parametamórficas, tais como migmatitos com intercalações de gnaisses cálcio-silicáticos e quartzosos, anfibolitos e quartzitos, equivalentes à rochas do Complexo Piracaia; mármores são raros. Estas rochas são invadidas por vários conjuntos de intrusões graníticas: série mangerítica provavelmente anorogênica, rochas cálcio-alcalinas em parte associada à charnoquitos, granitóides peraluminosos, série de granitóides porfííticos a equigranulares do tipo I Caledoniano, e uma série mais nova de granitóides róseos com suposta afinidade rapakivi; uma anomalia é o maciço Piracaia, monzonítico a monzodiorítico, e nota-se ainda a presença de sienitos como maciços circunscritos (e.g., na região de Caldas, MG) (ver também item 2.3, para maiores detalhes).

\subsection{AS ROCHAS METAMÓRFICAS NO DOMÍNIO SÃO ROQUE}

A faixa de rochas meta-sedimentares encontradas no Domínio São Roque é representativa de um conjunto de rochas claramente supracrustais, as do Grupo São Roque, com importante participação de materiais vulcânicos básicos nas suas partes basais; são totalmente desconhecidas as suas relações com as unidades metamórficas existentes mais para $\mathrm{N}$ e NW, das quais estão separadas por falhas resultantes da tectônica transcorrcnte. Litologicamente, são encontradas rochas metabásicas, mármores, metarenitos e quartzitos, metarcósios, xistos e filitos, em parte formando unidades claramente rítmicas.

Em princípio, as unidades basais do Grupo São Roque estão diretamente depositadas, aparentemente em discordância erosiva, por sobre a Unidade Gnáissica do Complexo Embu, que constituiria o seu embasamento; algumas das unidades rítmicas mostrariam sequências sedimentares indicativas de uma transgressão para $\mathrm{NW}$, em direção às regiỏes cratónicas aparentemente existente naquela época (ver Campos Neto \& Basei, 1983). Estudos mais recentes mostram que a unidade deve ser subdividida em dois grupos difertentes, o Grupo Serra do Itaberaba, basal, mostrando padrão próprio de deformação, metamorfismo regional mais intenso e contribuição significativa de metabasitos, e o Grupo São Roque, redefinido, com metamorfismo mais baixo da facies xistos verdes e litologias predominantemente metarenosas e metapelíticas, com frequência rítmicas (e.g., Juliani \& Beljavskis, 1995). O tema é discutido com maior detalhe no Capítulo 3. 


\subsection{A EVOLUÇÃO DO CONHECIMENTO SOBRE AS ROCHAS GRANÍTICAS DO ESTADO DE SÃO PAULO}

Observações pontuais já antigas, bem como mapeamentos de detalhe ou semidetalhe, em parte resultado de trabalhos de mestrado e doutorado, indicaram que o embasamento de São Paulo encontra-se cortado por inúmeras ocorrências de rochas granitóides, perfazendo no nível atual de afloramentos um total de aproximadamente $30 \%$ da superficie exposta.

\subsubsection{Características gerais dos granitóides do estado de São Paulo}

Algumas feições gerais podem ser extraidas da análise da literatura sobre os granitóides do estado de São Paulo (ver, por ex., as informaçðes contidas em Janasi \& Ulbrich, 1992). Em geral, trata-se de ocorrências petrografica e estruturalmente complexas, geralmente intrusões múltiplas, de dimensões desde moderadas ou pequenas (diques, bossas e plutons limitados) até batolíticas. Mostra-se, cada vez mais, que as ocorrências antes tidas como uniformes e de dimensões enormes devem, de fato, ser divididas em unidades menores, pela existência de intercalações e tabiques de rochas encaixantes, não observadas em trabalhos prévios de reconhecimento: é verificado, assim, que unidades tais como o gigantesco "batolito" Agudos Grandes, ou o de Três Corregos, são de fato "complexos" ígneo-metamórficos, formados por numerosas intrusões de menor extensão junto com rochas metamórficas e faixas de deformação. Uma feição notável é que não existe, aparentemente, local preferencial de localização destas intrusões graníticas: todos os "domínios" ou "blocos" geológico-estruturais em que pode ser dividido este embasamento encontram-se invadidos por igual, independentemente do tipo de rocha encaixante e do seu grau metamórfico, alto ou baixo. Em termos composicionais, predominam largamente as rochas mais evoluidas (monzo- e sienogranitos, granodioritos, por vezes também quartzo monzonitos); são mais raros os tonalitos (ou trondhjemitos), quartzo dioritos, monzonitos e afins, e mais ainda os dioritos. Ocorrências mostrando séries petrográficas expandidas não são as predominantes e, quando presentes, mostram passagem de quartzo-monzodioritos ou quartzo monzonitos para quartzo sienitos ou granitóides s.s. (e.g., as unidades do "batólito" Pinhal-Ipuiuna; Haddad, 1995). Rochas mais básicas são encontradas tipicamente como enclaves mais ou menos transformados (testemunhos de fenômenos de mistura magmática), mas é escassa a referência à corpos gabróides ou intermediários independentes e de dimensð̃es mapeáveis (e.g., no Complexo granítico-gnássico Socorro; Campos Neto \& Basei, 1983). A biotita é o mineral máfico predominante, frequentemente até nos termos claramente cálcio-alcalinos, com participação menos importante de anfibólios, frequentemente convertidos em biotita, totalmente ou em parte. É mínima a presença de clinopiroxênios, raramente observados e ainda assim quase sempre como relitos, exceto na associação de mangeritos e charnoquitos, onde vêm acompanhados de ortopiroxênios, ambas entretanto fases ricas em Fe e portanto "evoluidas"; estas rochas são de ocorrência restrita em São Paulo (e.g., no litoral de Ubatuba e regiões do Complexo Socorro) mas constituem, em Minas Gerais, um conjunto significativo de corpos alongados (e.g., Janasi, 1992). Em proporção menor, embora espalhados pela maioria dos domínios citados, aparecem os granitóides considerados de origem "crustal", identificados pela presença de muscovita primária e de granadas. É ainda ressaltada a existência de invasões sieníticas, em parte encontradas 
junto à granitóides, uma associação que, outra vez, aparece mais caracterizada em Minas Gerais.

\subsubsection{Trabalhos prévios}

Uma das primeiras tentativas de compilação e classificação mais abrangente dos granitóides dos estados de São Paulo e Paraná é devida a Hasui et al. (1978b), que separavam os granitóides em tipos sintectônicos e postectônicos. Os primeiros apresentam-se como corpos frequentemente maiores, com formas alongadas e contatos geralmente concordantes com as estruturas regionais e em parte com estruturas internas orientadas, enquanto que os segundos aparecem como corpos circunscritos e de dimensões limitadas, irregulares a elipsoidais-circulares, com texturas e estruturas não orientadas. A segunda divisão identificava várias "fácies" consideradas de distribuição regional. Assim, os granitóides sintectônicos são agrupados em duas "fácies", a migmatítica (gnaisses migmatíticos de variada estrutura e composição) e a denominada Cantareira de granitóides maciços a deformados, a última fácies por sua vez subdivida em "tipos" Tremembé (granito gnaisses s.1.), Santa Evelina (granitóides maciços com poucos fenocristais) e Pirituba (os típicos granitóides porfiríticos ou porfiróides, com abundantes fenocristais de microclínio constituindo até $50 \%$ da rocha); os do "tipo" Varejão, mais raros, mostram fenocristais em proporções superiores à matriz. Entre os granitóides de natureza póstectônica, são identificados os granitóides da "fácies" Itu (equigranulares maciços, cinzentos a róseos), que mostram ampla distribuição, e os da "fácies" Graciosa (alcalinos, com minerais máficos como anfibólios sódicos) e granofírica (com intercrescimentos granofiricos), os dois últimos com distribuição limitada ao SE paulista.

Janasi \& Ulbrich (1992), em compilação sobre os granitóides do estado de São Paulo, dividem o embasamento da região em vários "domínios", com base nas características das rochas metamórficas presentes e dos limites, todos eles de natureza tectônica (Tabela 2.1). Os domínios identificados são os de Iguape, Ubatuba, Embu, São Roque, Açungui, Jundiaí, Amparo e Guaxupé, cada um mostrando variado número de granitóides (Figura 2.4). As mais de 200 ocorrências granitóides citadas na literatura podem ser agrupadas em tipos diferentes, em função de suas características geológicas, petrográfico-mineralógicas e estruturais-texturais, e ainda as suas idajes (ver compilação citada; também Janasi \& Ulbrich, 1991). São identificadas as seguintes associações: uma antiga de ortognaisses de embasamento, tonalíticos a graníticos, de provável idade paleoproterozóica a pré-paleoproterozóica; uma suite mangerítica a charnoquítica deformada, de idade incerta (mesoproterozóica?), representando uma associação anorogênica; o conjunto dos grandes "batólitos" de biotita e hornblenda-biotita granitóides (e augen-gnaisses) pré-orogênicos; a associação de granitóides migmatíticos; os muscovita-biotita granitóides peraluminosos sin- a tardi-orogênicos; os biotita granitos a granodioritos cálcio-alcalinos sin- a tardi-orogênicos; as ocorrências pós-orogênicas. Um esquema simplificado de distribuição destas associações é reproduzido na Figura 2.4.

Campos Neto et al. (1990) identificam um conjunto variado de manifestações granitóides ligadas ao Ciclo Brasiliano (Figura 2.3). São catalogadas as seguintes associações ou "suites": uma mangerítica-charnoquítica, observada principalmente em Minas Gerais; uma cálcio-alcalina, cujo carâter potássico é caracterizado pela presença constante de biotita como máfico único ou principal, com anfibólio como fase 
subordinada; uma suíte peraluminosa à granada; a suíte dos granitóides porfiróides do tipo I Caledoniano, com espectro petrográfico pouco expandido, pelo predomínio de granitos e granodioritos; apenas um maciço monzodiorítico-monzonítico, o de Piracaia, como singelo representante de um magmatismo intermediário; uma suíte tardi-orogênica rósea ou rapakivi, assim chamada por mostrar alguns de seus representantes texturas rapakivi características; finalmente, uma suíte de sienitos, considerados de colocação tardia.

O grupo de trabalho de granitóides da UNESP de Rio Claro, sob a direção de E.Wernick, dedica-se faz anos ao estudo sistemático das manifestações granitóides presentes no estado de São Paulo, Minas Gerais e Paraná, utilizando mapeamentos faciológicos, estudos petrográficos, tipologia do zircão e dados geoquímicos e geocronológicos variados.

Os alvos de pesquisa dos trabalhos mais detalhados foram principalmente as ocorrências de Itu, São Francisco, Sorocaba, Itaqui, São Roque, Cantareira (e corpos vizinhos) e parte das manifestações relacionadas ao batólito ou Complexo Socorro, junto com estudos relativos à estratigrafia e petrologia-geoquímica das rochas de embasamento correlatas (complexos Pinhal, Amparo e Piracaia; migmatizações nos domínios Guaxupé, Amparo e Jundiaí). Os resultados obtidos foram divulgados em numerosas publicações, parte das quais dedicada à apresentação de ensaios abrangentes de síntese (e.g., Wernick, 1979, 1984, 1990; Wernick \& Penalva, 1978, 1980; Wernick \& Galembeck, 1985, 1987; Wernick et al., 1995; Artur \& Wernick, 1986). Esses estudos vem sendo enriquecidos, recentemente, com pesquisas sobre padrões de deformação das rochas granitóides e de sua anisotropia magnética (e.g., Ferreira, 1997).

Em 1978, Wernick \& Penalva propuseram uma sistematização dos granitóides presentes em três regiōes do embasamento cristalino de São Paulo: a Faixa dobrada Apiaí (domínios São Roque e Embu), a Zona Cristalina (domínios Amparo, Jundiaí e Guaxupé) e o Maciço Mediano de Joinville (dominios Iguape e Ubatuba). Na Faixa Apial, são identificados os grandes batolitos alongados (Cunhaporanga no Paraná, Três Corregos, São Francisco, São Roque, Itaqui, Cantareira, Piedade, Serra Branca), os de dimensð̃es intermediárias (Mairiporá,. Itaoca) e os menores (Tico Tico, Perus, etc.). Todos eles foram considerados tardi a pós-tectônicos, de colocação "mesotectônica" (conceito equivalente à "mesozonal") e polidiapíricos "restritos". Uma fase vulcânica tardia estaria presente no Grupo Castro, localizado em bacia molássica. As idades (em função de datações K/Ar já existentes) dos corpos tardi-tectônicos são da ordem de $620 \mathrm{Ma}$, enquanto que aos póstectônicos é atribuida uma idade em torno de $540 \mathrm{Ma}$; a idade de formação das bacias molássicas é da ordem de $425 \mathrm{Ma}$. $\mathrm{Na}$ Zona Cristalina são definidas três faixas. A SE está em contato tectônico com a Faixa Apiai, mostrando corpos granitóides circunscritos mesotectônicos, tardi- a pós-tectônicos (maciços Itu, Ponunduva, Atibaia, Nazaré). A zona central, mostra complexos catazonais ("catatectônicos") a mesozonais, com anatexitos e granitos porfiróides a equigranulares (maciços Socorro, Morungaba, etc.). A região N, finalmente, apresenta corpos tardi- a póstectônicos, junto com migmatitos (Grupo Pinhal). As idades dos maciços presentes nestas três zonas variam entre 620 e 540 Ma. No Maciço Mediano de Joinville ocorrem, outra vez, três faixas, com a NW mostrando grandes batolitos polidiapíricos e fases intrusvias desde sin- até tardi- e pós-tectônicas (maciços Agudos Grandes, Piedade) e que tem contatos tectônicos com as rochas supracrustais epizonais da Faixa Apiai. A zona central é ocupada por complexos sintectônicos, com feições anatexíticas (e.g., Complexo Paraibuna), enquanto que na zona SE aparecem 
corpos de dimensões reduzidas, em parte de tendência alcalina. Os corpos sintectônicos neste Maciço Mediano mostram idades de $650 \mathrm{Ma}$, os tardi-tectônicos $600 \mathrm{Ma}$ e os póstectônicos $540 \mathrm{Ma}$.

No trabalho de 1979, é apresentado por Wernick um agrupamento dos granitóides do estado de São Paulo, divididos em várias "suítes". A "suíte" sintectônica (650 \pm 30 $\mathrm{Ma}$ ), mostrando anatexitos e granitos porfiróides, presentes principalmente em maciços medianos e núcleos de geanticlíneos, é composta por duas associacões, a autóctone e a parautóctone-aloctone. A "suíte" tardi-tectônica $(540 \pm 25 \mathrm{Ma})$ é constituida por três associações litológicas (tonalito-granito; monzonito-adamellito; álcali granito-sienito), enquanto que a pós-tectônica (510-460 Ma) engloba as manifestações circunscritas mais recentes e de dimensões menores (até diques, etc.), em parte com uma fase vulcânica molássica.

Tabela 2.1. Os domínios geológicos no embasamento paulista

\begin{tabular}{|ll|}
\hline Domínio & Características das rochas metamórficas predominantes \\
\hline Iguape & $\begin{array}{l}\text { Embasamento de rochas arqueanas a paleoproterozóicas } \\
\text { (migmatitos, ortognaisses e granulitos do Complexo Costeiro) e } \\
\text { faixa de xistos supracrustais mesoproterozóicos de grau baixo a } \\
\text { médio (Complexo Paraibuna). }\end{array}$ \\
\hline Ubatuba & $\begin{array}{l}\text { Ortognaisses (paleoproterozóicos?; arqueanos?) de alto grau } \\
\text { (Complexo Costeiro). }\end{array}$ \\
\hline Embu & $\begin{array}{l}\text { Complexo Embu (para NE: gran-sillim xistos e paragnaisses de alto } \\
\text { grau) e Complexo Pilar (para SW: xistos e filitos mesoproterozóicos } \\
\text { de grau baixo a médio). }\end{array}$ \\
\hline Açungui & $\begin{array}{l}\text { De NW para SE: faixa setentrional, sequência meta-vulcano- } \\
\text { sedimentar de baixo grau (Grupo Itaiacoca); faixas central e } \\
\text { meridional, meta-supracrustais de baixo grau (Grupos Açungui e } \\
\text { Lajeado). }\end{array}$ \\
\hline São Roque & $\begin{array}{l}\text { Grupo São Roque, superior, metassedimentos brasilianos (ou pré- } \\
\text { brasilianos?), de baixo grau; Grupo Serra do Itaberaba (meso- a } \\
\text { paleoproterozóicos), inferior, com rochas metabásicas, mármores, } \\
\text { metassedimentos, de grau baixo a médio. }\end{array}$ \\
\hline Amundiai & $\begin{array}{l}\text { Complexo Piracaia: predominam rochas supracrustais de alto grau, } \\
\text { parcialmente migmatizadas (biotita gnaisses e xistos, em parte com } \\
\text { granada e sillimanita; quartzitos) }\end{array}$ \\
Grupos Andrelândia e Itapira: rochas supracrustais \\
mesoproterozóicas de grau baixo a médio.
\end{tabular}

Fonte: Janasi \& Ulbrich $(1991,1992)$. 


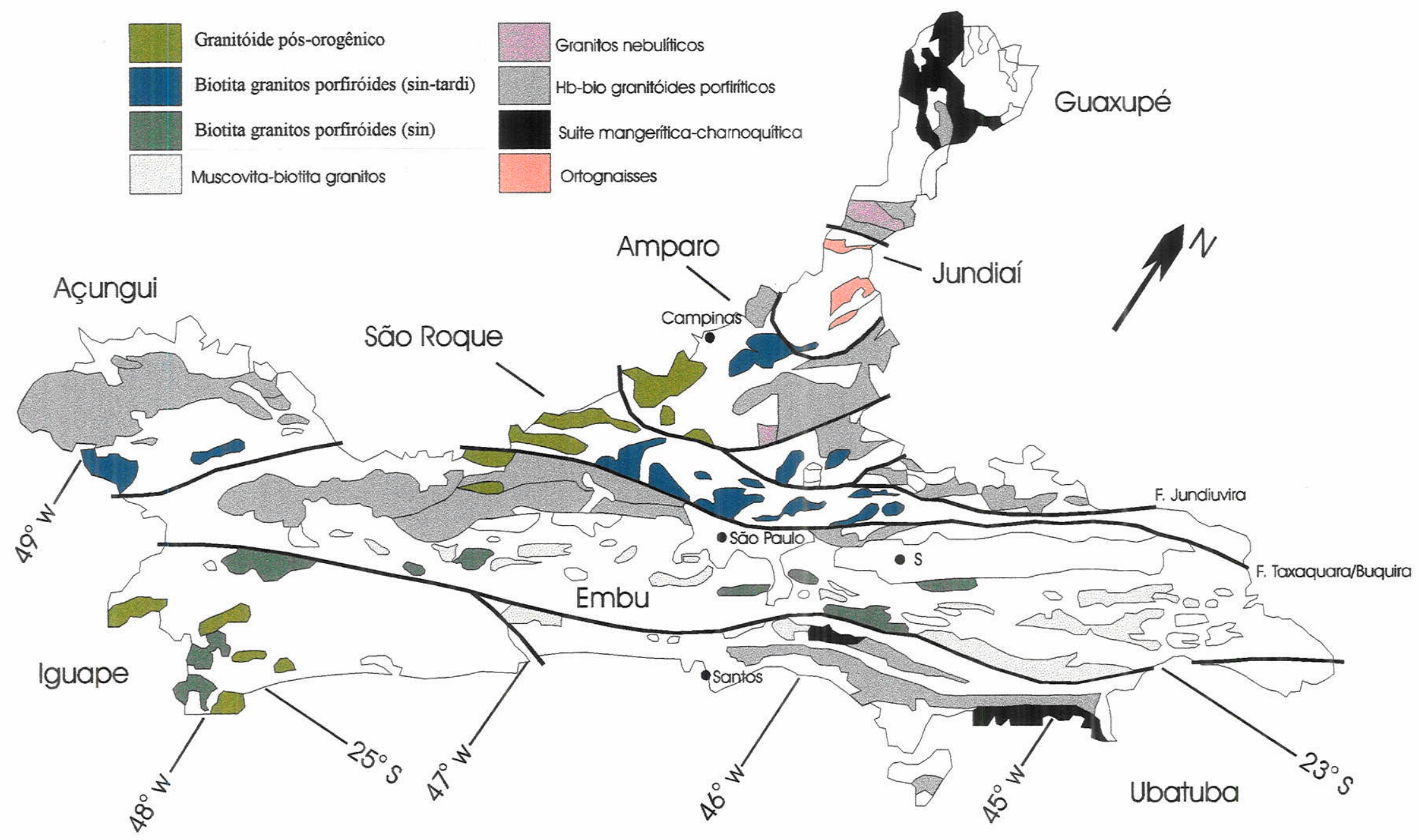

Figura 2.4. As principais ocorrências de granitóides no estado de São Paulo (Janasi \& Ulbrich, 1992) 
Uma relação entre movimentações de placas, subducção e granitogênese foi proposta por vários autores, com base em modelos difundidados na literatura. Entre eles, aparecem ensaios de Wernick $(1984,1990)$ e Wernick \& Galembeck (1985), relacionando os eventos brasilianos e pré-brasilianos com a aparição de uma zona de subducção e a posterior colisão direta entre as placas Kalahari e Rio de la Plata (e o bloco ou craton Paraná), estabelecendo-se assim a possibilidade de geração de vários tipos de granitóides (cálcio-alcalinos mais e menos profundos, crustais rasos, subalcalinos e alcalinos profundos, etc.).

O reconhecimento destas associações e o seu posicionamento em mapa definiria assim uma "polaridade" dos granitóides, identificando ao mesmo tempo o sentido do mergulho da paleozona de Benioff responsável pela geração dos magmas granitóides correspondentes. No trabalho de 1984, Wernick propõe um primeiro modelo, estabelecendo uma sequência de granitos cálcio-alcalinos mais profundos para W-NW e a aparição de granitos "crustais" de profundidades rasas localizados perto da cidade de São Paulo, com polaridade para W-NW e idéntico mergulho da zona de Benioff geradora. Em trabalhos posteriroes do grupo de Rio Claro, é utilizada adicionalmente a ferramenta da tipologia do zircão, conforme o método de Puppin, que permite identificar 10 tipos morfológicos diferentes desta fase acessória, que estariam claramente relacionados com determinadas associações magmáticas (3 tipos com os granitóides "crustais", outros 3 identificando os cálcio-alcalinos, e 4 tipos adicionais definindo, respectivamente, a associação subalcalina, a alcalina, a toleítica e a charnoquítica). $O$ zoneamento magmático estabelecido por meio desta tipologia aponta para um modelo com "polaridade" tanto para $\mathrm{N}$ ( em função dos indícios obtidos dos zircões dos complexos, em MG, e Pinhal e os maciços Socorro e Morungaba) como para W (zircões dos maciços Mairiporá, Cantareira e Itaqui -menos profundos- até os do maciço Sorocaba, mais profundo), lembrando ainda da existência de granitos de origem rasa em volta da cidade de São Paulo (Wernick, 1990; Wernick \& Galembeck, 1985); não fica descartada, entretanto, a possibilidade de uma subducção para $E$ em São Paulo, com o quadro atual de localização dos maciços controlada por esforços regionais N-S e a configuração final em blocos distintos (=domínios) por ação das falhas transcorrentes com deslocamentos NE-SW (Wernick, 1990).

\subsubsection{Idades dos granitos}

Na literatura específica, os granitóides do estado de São Paulo são agrupados, de maneira quase unânime, com utilização de esquemas difundidos na literatura internacional, conforme as suas características geológico-estruturais (e.g., os de autores europeos e americanos tais como Eskola, Buddington, Henderson e Hutchinson: sin- a pós-tectônicos, epizonais a catazonais, "catatectônicos" até "epitectônicos", etc.; ver, por ex., Hasui et al., 1978b; Wernick \& Penalva, 1978; Janasi \& Ulbrich, 1991; e bibliografia alí citada). Os corpos sinstectônicos seriam alongados, muitas vezes batolíticos, concordantes regional e até localmente, com texturas porfíriticas frequentes ou até predominantes, associados com áreas migmatíticas, em parte deformados, enquanto que os pós-tectônicos apresentar-se-iam como corpos circunscritos, de dimensões menores, equigranulares, em parte epizonais, etc. 
As primeiras datações $\mathrm{K} / \mathrm{Ar}$ em rochas granitóides e metamorfitos vários (Cordani \& Bittencourt, 1967; Hasui \& Hama, 1972; Tabela 2.2) indicavam uma idade entre 650 a $600 \mathrm{Ma}$ para o metamorfismo principal e a intrusão de granitos sin-tectônicos, enquanto que os tardi-tectônicos teriam se colocado por volta de $590 \mathrm{Ma}$. Datações $\mathrm{Rb} / \mathrm{Sr}$ (Cordani \& Kawashita, 1971; Tabela 2.2) sugerem um evento de invasão tardi-tectônica de $608 \pm$ $48 \mathrm{Ma}$ e outro pós-tectônico datado em $544 \pm 11 \mathrm{Ma}$. Em trabalho de integração (Cordani \& Teixeira, 1979), era indicado um intervalo de 640 a $470 \mathrm{Ma}$ para os eventos metamórficos, intrusivos e de resfriamento final do ciclo orogênico brasiliano no embasamento paulista; os granitos sintectônicos teriam idade da ordem de $640 \mathrm{Ma}$, os pós-tectônicos entre 560 e $490 \mathrm{Ma}$. Outros autores aceitam, em termos gerais, estas divisões, enfatizando que os corpos granitóides sin-tectônicos colocaram-se por volta de $650 \mathrm{Ma}$ atrás, enquanto que os tardi-tectônicos mostravam idades em torno de $540 \mathrm{Ma}$ (e.g., Wernick \& Penalva, 1978, 1979; para literatura e uma compilação de idades, ver Tassinari, 1988; Janasi \& Ulbrich, 1991).

Trabalhos posteriores confirmaram em parte este diagnóstico, sem eliminar completamente as incertezas. Assim, as rochas da associação "anorogênica" deformada de mangeritos e charnoquitos (e granitos associados) mostrariam idade provável de 750(?) $\mathrm{Ma}$, selecionada de um conjunto de dados que varia entre 933 a $650 \mathrm{Ma}$ (Janasi, 1992; ver também Janasi \& Ulbrich, 1991; Tabela 2.2). A "fase I" de granitóides porfíriticos iniciais de Socorro (Artur et al., 1991) mostra uma idade U-Pb (em zircão) de $650 \mathrm{Ma}$ e idades isocrónicas $\mathrm{Rb} / \mathrm{Sr}$ de $660 \mathrm{Ma}$ (C.Tassinari, com. pessoal: referência em Janasi \& Ulbrich, 1991; Artur \& al., 1991), enquanto que a "fase II" de granitos equigranulares de Socorro teria se colocado por volta de 500 a $550 \mathrm{Ma}$ (Artur et al., 1991). Existe uma datação U-Pb em zircão de $669 \mathrm{Ma}$ para rochas do maciço Cantareira ((Tassinari, 1988; ver também Tabela 2.2). Os granitos porfiriticos da parte setentrional de Morungaba mostram idades isocrónicas $\mathrm{Rb} / \mathrm{Sr}$ da ordem de 610 a 615 ( \pm 10 a 15) Ma, os da parte meridional e os orientais equigranulares outras por volta de $590 \mathrm{Ma}$, sugerindo portanto um intervalo relativamente pequeno entre a atividade intrusiva sin-orogênica a tardi-e pós-orogênica (Vlach, 1993). Os granitos "crustais" (e.g., Nazaré) apresentariam idades entre 650 a 550 $\mathrm{Ma}$ (datações em rochas graníticas e em veios de anatexia; Artur et al., 1991); estas idades, junto com as conhecidas para o maciço Tico-Tico (Tabela 2.2), definiriam um longo periodo de atividade para o magmatismo de origem "crustal" (tipo "Nazaré paulista" e similares).

Estudos mais recentes, com uma maior aplicação da metodologia U/Pb para datação dos maciços em questão, confirmam que o conjunto dos granitóides brasilianos foi gerado em intervalo de tempo provavelmente curto (entre 650 a $580 \mathrm{Ma}$ ), mas marcado por picos de atividade magmática (e.g., Janasi et al., 1995). Algumas datações mais recentes são encontradas em Basei et al. (1995) e Ebert et al. (1996), caracterizando mangeritos de São José do Rio Pardo, MG, e granitos deformados e sem deformação do Complexo Socorro, SP-MG, e principalmente em Töpfner (1996), obtidas para os maciços Itaqui (fácies Barueri), Cantareira, Socorro, Tico-Tico e Itu (intrusão Cabreúva) (Tabela 2.2). As últimas determinações mencionadas (Töpfner, 1996) são datações U-Pb em grãos de zircão de dimensões pequenas e que mostram pouca ou nenhuma suscetibilidade magnética (tratando-se então, possivelmente, de grãos de verdadeira filiação magmática, sem núcleos reciclados e sem inclusões de fases magnéticas). Observe-se que as dataçð̃es para Socorro, Itaqui e Cantareira, e até para o granito "crustal" Tico-Tico, são 
inteiramente coincidentes (Tabela 2.2), variando apenas entre 625 e $630 \mathrm{Ma}$ (portanto, dentro do margem de erro); a datação para os granitos róseos Itu é divergente, de $583 \mathrm{Ma}$.

Falta ainda um maior número de datações para os granitóides tidos como claramente pós-tectônicos (e.g., fases finais, eventualmente filonianas, em Itu e Morungaba; Mandira; etc.) e para os outros granitóides considerados "sin-tectônicos" e os de origem parcial ou totalmente "anatexítica" (e.g., Complexo Pinhal, tipo "Nazaré paulista", os "batólitos" alongados do tipo Piedade, Natividade, etc.), antes de poder definir, sem equívocos, os possiveis picos da atividade magmática granítica e as relações gerais com os eventos metamórficos e de deformação.

Em princípio, os últimos dados $\mathrm{U} / \mathrm{Pb}$ citados levam às seguintes conclusões:

1) é muito dificil estabelecer uma sequência geocronológica, com suficiente confiabilidade, com base unicamente em datações $\mathrm{K} / \mathrm{Ar}$ e $\mathrm{Rb} / \mathrm{Sr}$, em terrenos com histórias geológicas tão complexas como o embasamento presente nas várias regióes do $\mathrm{SE}$ brasileiro. Esses sistemas isotópicos são abertos, por estarem retidos os isótopos correspondentes em minerais como micas e feldspatos, que reagem com facilidade frente à variações nos gradientes de temperatura e pressão e a movimentação de fluidos metamórficos e os de origem magmática. Mostram assim idades muito díspares, por vezes totalmente divergentes, em geral com intervalos muito grandes de confiabilidade (tipicamente, superiores aos 20 ou $30 \mathrm{Ma}$, frequentemente superiores à $100 \mathrm{Ma}$; Tabela $2.2)$

2) Não todas as dataçõs U/Pb são válidas, já que muitos grãos de zircão podem refletir histórias prévias, gerando-se então concórdias que identificam interceptos com erros significativos.

3) Mesmo assim, as últimas datações $\mathrm{U} / \mathrm{Pb}$ mais confiáveis parecem estar confirmando pelo menos dois possíveis picos de atividade magmática, um em torno de $630 \mathrm{Ma}$ para rochas em maciços sin-tectônicos, outro em torno de $580 \mathrm{Ma}$ para a atividade considerada "tardi-tectônica": com isto, ficaria estabelecido que são gerados, por volta de $630 \mathrm{Ma}$, corpos granitóides de caracteristicas extraordinariamente diferentes em intervalos de tempo muito curtos (desde granitos tipicamente cálcio-alcalinos até os de natureza francamente "crustal"). Estas idades posicionam-se ainda dentro do intervalo de idades estabelecido pelas datações $\mathrm{K} / \mathrm{Ar}$ e $\mathrm{Rb} / \mathrm{Sr}$, mas as definem com maior grau de confiabilidade.

4) Em caso de confirmar-se as últimas datações U/Pb, fica claro que os granitóides "sintectônicos", formados por volta de $630 \mathrm{Ma}$, mostrariam apenas em parte as características geológico-estruturais (estruturas internas, petrografia, texturas porfiríticas predominantes, concordâncias regionais ou locais, etc.) que os modelos corriqueiros da literatura identificam como "específicos" desse grupo; por exemplo, os granitos à dois micas e com granada do maciço Tíco-Tico, claramente um granitóide do tipo S, são unanimente considerados como pertencentes à categoria diferente à dos granitóides predominantes do maciço batolítico Socorro, presumindo-se portanto, provavelmente, idades também diferentes. 
Tabela 2. 2. As associações granitóides no estado de São Paulo: características e idades

\begin{tabular}{|c|c|c|c|c|}
\hline Associação & Maciços & Feiçðes gerais & $\begin{array}{l}\text { Idades, Ma (até } \\
\text { 1991) }\end{array}$ & $\begin{array}{l}\text { Determinações pós- } \\
1991\end{array}$ \\
\hline \multirow[t]{2}{*}{$\begin{array}{l}\text { Mangeritos } \\
\text { charnoquitos }\end{array}$} & S.J. do Rio Pardo & $\begin{array}{l}\text { Foliados, transicionais } \\
\text { para granitos }\end{array}$ & $\begin{array}{l}\mathrm{Rb}(\mathrm{i}) \quad 933(16) \quad \mathrm{a} \\
650(40)\end{array}$ & $\mathrm{U}($ zir) 624 (7) BA \\
\hline & Ubatuba & $\begin{array}{l}\text { Foliados, } \\
\begin{array}{l}\text { assoc. a aciços, } \\
\text { róseos }\end{array}\end{array}$ & $\mathrm{Rb}(\mathrm{i}) 558(3)$ & \\
\hline \multirow[t]{3}{*}{$\begin{array}{l}\text { Batólitos cálcio- } \\
\text { alcalinos alongados }\end{array}$} & Socorro & $\begin{array}{l}\text { A) Gnaisses e granitos } \\
\text { porfir. c/hbl.; B) gran. } \\
\text { equigran. tardios }\end{array}$ & $\begin{array}{l}\text { A) U(zir) } 650(5) \text {; } \\
\text { B) } \mathrm{Rb}(\mathrm{i}) 880(62)\end{array}$ & $\begin{array}{l}\mathrm{U}(\mathrm{zir}) 629(3) \mathrm{T} 2 ; \mathrm{Rb}(\mathrm{i}) \\
625(71) \mathrm{T} 2 ; \mathrm{A}) \mathrm{U(zir)} \\
\sim 650 \mathrm{~EB} ; \mathrm{B}) \mathrm{U}(\mathrm{zir}) \\
-595 \mathrm{~EB}\end{array}$ \\
\hline & Pinhal-Ipujúna & $\begin{array}{lr}\text { A) granit. porfir. } \\
\text { iniciais; } & \text { B) } \\
\text { porfiriticos; C) } & \text { tardios } \\
\text { róseos porfir. } \\
\end{array}$ & & \\
\hline & $\begin{array}{l}\text { Butantå-Santa } \\
\text { Isabel }\end{array}$ & Gnaisses & $\begin{array}{l}\text { U(zir) } 660(13) ; \\
\mathrm{Rb}(\mathrm{i}) \text { 645(38) }\end{array}$ & \\
\hline \multirow[t]{2}{*}{ Migmatitica } & Pinhal & Nebulitos c/ biot & $\begin{array}{ll}\mathrm{Rb}(\mathrm{i}) & 570(6) ; \\
833(9) & \\
\end{array}$ & \\
\hline & Nazaré & $\begin{array}{l}\text { Granit. nebuliticos o/ } \\
\text { gra-biot }\end{array}$ & $\mathrm{Rb}(\mathrm{i}) 790(32)$ & \\
\hline \multirow[t]{6}{*}{ Sin-, tardi-tectônicos } & Cantareira & $\begin{array}{l}\text { Porfir., em parte } \\
\text { foliados }\end{array}$ & $\begin{array}{l}U(\text { zir) } 669(8) \\
R b(i) 625(85)\end{array}$ & $\begin{array}{l}\mathrm{U}(\mathrm{zir}) 572(9) \mathrm{T} 1 ; \mathrm{U}(\mathrm{zir}) \\
630(8) \mathrm{T} 2 ; \mathrm{Rb}(\mathrm{i}) 625 \\
(84) \mathrm{T} 2\end{array}$ \\
\hline & Itaqui & $\begin{array}{ll}\text { Gran. } & \text { variados, } \\
\text { equi/porfir. } & \\
\end{array}$ & & $\begin{array}{lccc}\mathrm{U}(\mathrm{zir}) & 624 & (11) & \mathrm{T} 2 \\
\mathrm{Rb}(\mathrm{i}) & 626(19) & \mathrm{T} 2 & \\
\end{array}$ \\
\hline & São Roque & Variados & & \\
\hline & Tico-Tico & Gran.c/musc-gra-biot & $\begin{array}{l}\mathrm{Rb}(\mathrm{i}) \quad 700(20) \\
\mathrm{K} / \mathrm{Ar}(\mathrm{bi}) 580(20)\end{array}$ & $\begin{array}{l}\mathrm{U}(\mathrm{zir}) \quad 626 \quad(21, \mathrm{Tl}) ; \\
\mathrm{U}(\mathrm{zir}) \\
625(18, \mathrm{~T} 2) ; \mathrm{Rb}(\mathrm{i}) \\
600(54, \mathrm{~T} 2)\end{array}$ \\
\hline & Perus & Turm gran c/gra & $\mathrm{K}(\mathrm{lep}) 650(20)$ & $\mathrm{U}(\mathrm{mo}) 566(6, \mathrm{Tl})$ \\
\hline & Natividade & $\begin{array}{l}\text { Porf., com biot., em } \\
\text { parte com musc. }\end{array}$ & $\mathrm{Rb}(\mathrm{i}) 570(50)$ & \\
\hline \multirow[t]{2}{*}{$\begin{array}{l}\text { Tardi- a pós- } \\
\text { tectônicos }\end{array}$} & Morungaba & $\begin{array}{l}\text { A) c/musc., iniciais; } \\
\text { B) Gran. porfir.; C) } \\
\text { meridional, equigran.; } \\
\text { D) Granofirico, tardio }\end{array}$ & $\begin{array}{l}\text { B) } \mathrm{Rb}(\mathrm{i}) \text { 612(18); } \\
\text { C) } \mathrm{Rb}(\mathrm{i}) 590(10) \text {; } \\
\text { D) KJ/Ar } \mathrm{RT} \\
523(26)\end{array}$ & \\
\hline & Sorocaba & $\begin{array}{l}\text { Bio gran porfir. } \\
\text { predominantes }\end{array}$ & $\mathrm{K}(\mathrm{bi}) 573(25)$ & \\
\hline \multirow[t]{2}{*}{ Pós-tectônicos } & Itu & $\begin{array}{ll}\begin{array}{l}\text { Variados, } \\
\text { c/biot., em }\end{array} & \begin{array}{l}\text { gran. } \\
\text { parte }\end{array} \\
\text { rapakivi } & \end{array}$ & $\mathrm{Rb}(\mathrm{i}) 586(10)$ & $\begin{array}{l}\mathrm{U}(\mathrm{zir}) 583(6, \mathrm{~T} 2) ; \mathrm{Rb}(\mathrm{i}) \\
583(20, \mathrm{~T} 2)\end{array}$ \\
\hline & Saro Francisco & $\begin{array}{l}\text { Gran.porfir. } \\
\text { equigran., em parte } \\
\text { rapakivi }\end{array}$ & $\mathrm{K} / \mathrm{Ar}$ (bi) $540(25)$ & \\
\hline
\end{tabular}

Associação: segundo agrupamento de Janasi \& Ulbrich (1991). Gran: granitos a granodioritos; equi., porf.: equigranulares, porfííticos; bi ou biot, gra, hbl, mo, musc, turm, zir: biotita, granada, hornblenda, monazita, muscovita, turmalina, zircão; $R b(i)$ : isócrona $\mathrm{Rb} / \mathrm{Sr} ; K / A r(b i, R T)$ : idade $\mathrm{K} / \mathrm{Ar}$ em biotita ou rocha total; $U$ (zir,mo): idade U/Pb em zircão ou monazita; 540(25): erros da idades entre parêntesis. Fonte (até 1991): compilação de Janasi \& Ulbrich (1991). Datações posteriores: BA: Basei et al. (1995); EB: Ebert et al. (1996); T1: Teuppenhayn (1994); T2: Töpfner (1996). 


\section{CAPÍTULO 3}

\section{A GEOLOGIA DAS FOLHAS SANTANA DO PARNAÍbA E GUARULHOS}

A região estudada nesta dissertação encontra-se centrada na localidade de Perus, aproximadamente no centro geográfico do domínio São Roque. Representa este uma extensa faixa crustal com orientação aproximada $\mathrm{NE}$ e percurso de uns $200 \mathrm{Km}$, mais larga na sua porção ocidental, onde desaparece por baixo da cobertura da bacia do Paraná, estreitando-se progressivamente para nordeste, em direção ao estado do Rio de Janeiro. É limitado a norte pelo falhamento de Jundiuvira e a sul pelo de Taxaquara-Jaguari-Boquira (ver localização, extensão e limites na Figura 2.4). O ciclo termotectônico brasiliano, estabelecido entre 700 e $450 \mathrm{Ma}$ (Almeida et al., 1978), é reconhecido nesta faixa através de intenso retrabalhamento crustal marcado por deformação e dobramentos, metamorfismos de grau baixo a médio nos metassedimentos, a geração de zonas de cisalhamento e a colocação de grandes volumes de rochas granitóides. Como unidades geológicas fundamentais, são encontradas por um lado as rochas metamórficas de grau baixo a médio pertencentes aos grupos Serra do Itaberaba e São Roque e, por outro, as variadas manifestações graníticas de idade brasiliana; 0 embasamento dos metassedimentos, de possível idade eoproterozóica (a arqueana?) aflora em áreas reduzidas. As coberturas mais modernas, por sua vez, limitan-se à existência de depósitos de colúvio e sedimentos fluviais ao longo das drenagens, pouco expressivas.

São vários os estudos realizados por diversos autores nesta região, em parte acompanhados por mapeamentos parciais ou completos, que abrangem as folhas topográficas em escala 1:50.000 Santana do Parnaiba e Guarulhos. Entre estes, devem ser mencionados em particular os de Carneiro (1983), Bergmann (1988), Juliani et al. (1986), Dantas (1990), Juliani (1993) e Coutinho (1980); dados adicionais sobre a geologia do maciço Itaquí são encontrados em Ferreira (1991).

Os mapas litológicos e estruturais apresentados nos trabalhos de Carneiro (1983), Bergmann (1988), Dantas (1990) e Ferreira (1991) foram aqui utilizados para a realização de um mapa de compilação, com a finalidade de estabelecer as bases para interpretaçóes mais abrangentes e, em particular, para documentar forma e distribuição dos diversos maciços graníticos, de filiação cálcio-alcalina até francamente crustal, que são encontrados na região. Algumas feições estruturais são também incluidas, principalmente os dados estruturais sobre forma e distribuição das várias gerações de dobras e dos múltiples sistemas de fraturas e falhas; não foram incluidos, entretanto, dados sobre disposição e mergulho de foliações em rochas metamórficas e milonitos, para não sobrecarregar o mapa de compilação. Esta compilação regional é apresentada como Anexo 1 (encarte), reduzido para uma escala 1:100.000; para facilidade do leitor, o Anexo 1 é reproduzido em escala mais apropriada na Figura 3.1. 


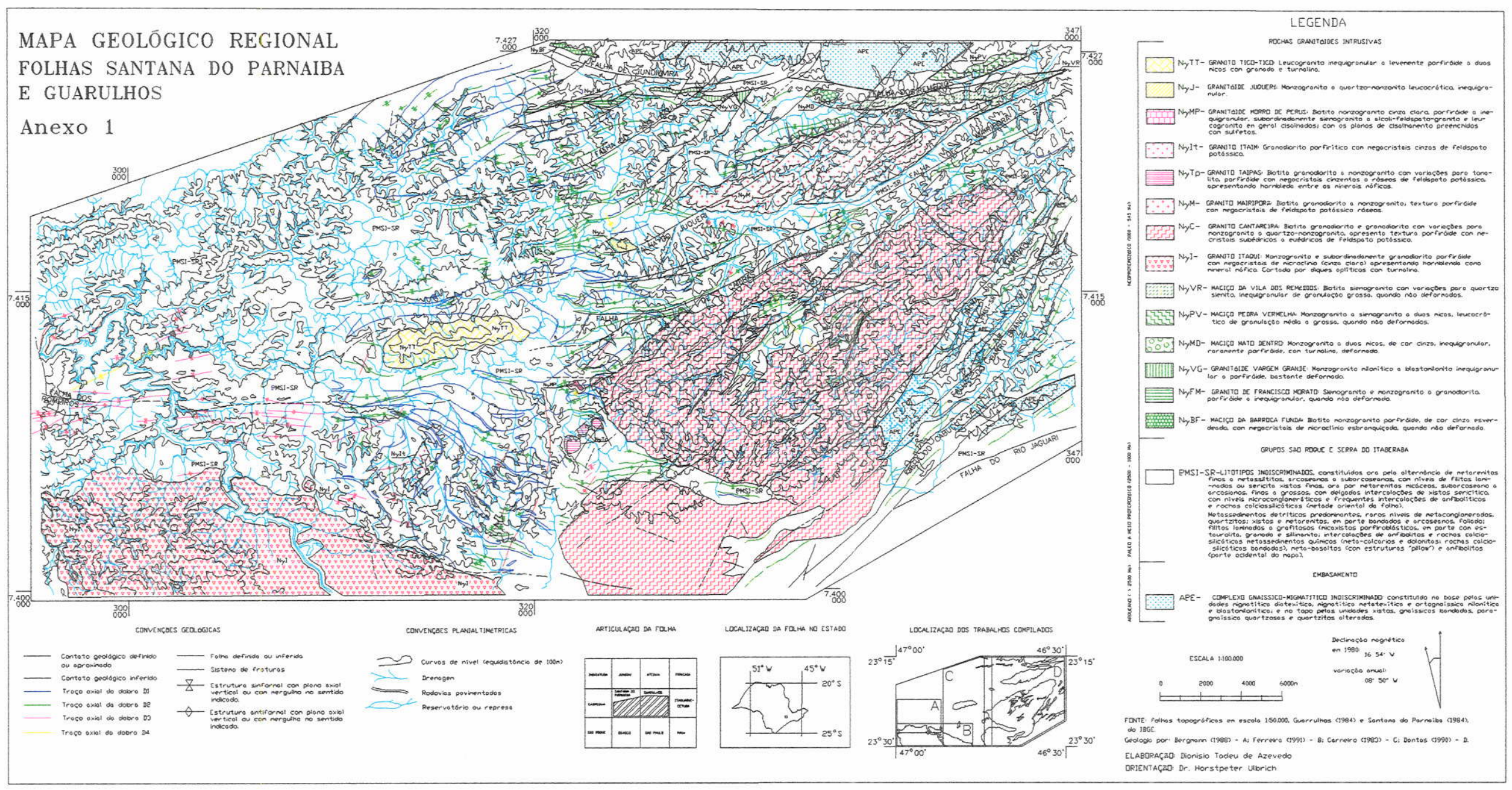


Em sequência, são descritas a seguir as unidades apresentadas no Anexo 1: o embasamento gnáissico-migmatítico, o conjunto de metassedimentos e rochas metamórficas ortoderivadas associadas, os vários tipos de granitóides, e a cobertura recente.

\subsection{EMBASAMENTO}

O embasamento presente nesta região do domínio São Roque é observado em janelas estruturais geralmente próximas às grandes zonas de cisalhamento, identificadas como Complexo gnáissico-migmatítico indiscriminado no Anexo 1. Uma parte é setentrional, com afloramentos em geral situados além da Zona de cisalhamento Jundiuvira e dos Remédios, portanto fora dos limites do Domínio São Roque. A outra região é encontrada na parte centro-leste do mapa, à $\mathrm{E}$ do maciço Cantareira, limitada pelas zonas de cisalhamento Mandaquí e a falha do Rio Jaguari. Dantas (1990) divide este conjunto em duas unidades, a inferior constituída por três subunidades, a dos migmatitos diatexiticos, dos metatexíticos e dos ortognaisses miloníticos e blastomiloníticos, e a superior, formada por xistos, gnaisses bandados, paragnaisses quartzosos e quartzitos.

A unidade inferior, com posicionamento estratigráfico inferior, apresentaria três subunidades. A dos migmatitos diatexíticos mostra rochas migmatíticas com o neossoma predominante sobre o paleossoma, com desenvolvimento de estruturas homófonas a nebuliticas e texturas em geral deformadas; adicionalmente aos afloramentos principais na parte $\mathrm{N}$ da falha de Jundiuvira, apareceriam ainda migmatitos similares (augengnaisses) perto da cidade de Guarulhos, na parte centro-leste do mapa regional. O neossoma é constituído de biotita granito e biotita-hornblenda granito, com termos quartzo monzograníticos a quartzo dioríticos mais subordinados. $O$ paleossoma mostra-se como relitos difusos constituído de biotita e muscovita xistos e núcleos anfibolíticos. A subunidade dos migmatitos metatexíticos é encontrada também principalmente na região $\mathrm{N}$ (além da falha de Jundiuvira), com poucos afloramentos na parte centro-leste; apresenta a fração paleossomática dominante sobre a neossomática, onde ocorre o desenvolvimento de estruturas estromáticas, arteríticas dobradas e schollen, com grau de migmatizacão variado. O paleossoma é representada por gnáisses biotíticos, micaxistos feldspáticos e ainda bolsões anfibolíticos irregulares e quartzitos granatíferos. $O$ neossoma consiste de porções pegmatóides, de composição granítica, que ocorrem como vênulas irregulares ou massas disformes. A terceira subunidade, a dos ortognaisses miloníticos $e$ blastomiloníticos, é representada por rochas graníticas deformadas, leucocráticas de coloração cinza clara variando para rósea e cinza escuro, de composição predominante monzogranítica a sienogranítica, com termos granodioríticos e quartzo monzoníticos subordinados; ocorrem principalmente na região centro-leste. A estrutura da rocha é gnáissica, marcada pelo alinhamento da biotita e orientação dos cristais alongados de quarzto e feldspatos, com desenvolvimento de texturas blastomiloníticas a miloníticas. Os três constituintes da unidade inferior mostram relações de contatos transicionais, variáveis de acordo com grau de migmatização.

A unidade superior ocorre quase unicamente na parte $\mathrm{N}$ do mapa de compilação, com seus três litotipos mostrando aparentemente contatos transicionais entre si e para alguns dos migmatitos previamente citados; são rochas menos abundantes. Os xistos, 
encontrados em pequeno afloramentos à NW, são constituidos por sillimanita (fibrolita)muscovita xistos e muscovita xistos de granulação grosseira mostrando textura granolepidoblástica; representam, provavelmente, o paleossoma não migmatizado dos migmatitos metatexíticos da unidade inferior (ver acima). Os gnaisses bandados, que incluem biotita gnaisses e biotita-muscovita gnaisses a sillimanita e/ou cordierita, caracterizam-se pela alternância, centimétrica a decimétrica, de bandas quartzofeldspáticas e xistosas. As bandas félsicas, de cor creme a cinza clara e textura porfiroclástica, mostram composição granodiorítica a monzogranítica; nos níveis xistosos, mostrando textura granolepidoblástica, os componentes são biotita, quartzo, plagioclásio, microclínio, muscovita e sillimanita (fibrolitizada) como minerais principais e zirção, rutilo, opacos, turmalina e por vezes cordierita como acessórios. Os paragnaisses quartzosos e quartzitos constituem um litotipo bandado com alternância centimétrica a decimétrica de biotita ganaisses quartzosos e biotita quartzitos; as melhores exposicões, ao $\mathrm{N}$, estão em parte fora da abrangência da área do Anexo 1.

Dantas (1990) considera que a unidade inferior de migmatitos de seu Complexo gnáissico-migmatítico possa ser correlacionável ao Grupo Amparo (considerado transamazônico, com idade superior aos $2,1 \mathrm{Ga}$ ou até $3,4 \mathrm{Ga}$ ), enquanto que a superior, que mostra passagem transicional inferior (e aparentemente também lateral) para os migmatitos, deve ser atribuída ao Grupo Itapira (idades de retrabalhamento da ordem de $1,9-2,1 \mathrm{Ga})$.

Carneiro (1983) identifica alguns pequenos afloramentos de embasamento, que são divididos pelo autor em duas unidades ou faixas longitudinais de tendência NE, com contatos tectônicos e largura de alguns centos de metros cada uma. A primeira é a de gnaisses e migmatitos, supostamente correlacionáveis ao Complexo Amparo, de idade eoproterozóica a arqueana, encontrada perto do entroncamento entre as duas rodovias Bandeirantes e Anhanguera. A outra é a faixa de milonito-gnaisses e blastomilonitos, localizada à SE da unidade anterior, a poucos centos de metros; é de atribuição estratigráfica incerta. A primeira unidade é constituída principalmente por biotita gnaisses quartzo-feldspáticos, frequentemente com sillimanita, por vezes também com muscovita, hornblenda e granada. A segunda mostra milonitos, em parte com porfiroclastos de feldspatos, dobrados em algumas localidades. As exposições ce ambas unidades estão localizadas fora da área representada no Anexo 1 (ver a folha norte do trabalho de Carneiro, 1983).

\subsection{OS METASSEDIMENTOS E ROCHAS ASSOCIADAS: OS GRUPOS SÃO ROQUE E SERRA DO ITABERABA}

No Anexo 1, as rochas que constituem o Grupo São Roque (hoje subdividido em grupos Serra do Itaberaba, inferior, e São Roque, superior) aparecem como um único conjunto indiferenciado, ja que não existe consenso entre os vários autores sobre as possíveis unidades mapeáveis constitutivas, não sendo portanto possível representar essas variações no presente mapa de compilação. Observa-se, na legenda do Anexo 1, que o conjunto de litotipos atribuídos ao Grupo Serra do Itaberaba é algo diferente daquele encontrado no Grupo São Roque, destacando-se também as diferenças no seu grau metamórfico. Na compilação são também marcadas as feições estruturais propostas por 
estes autores: os eixos de dobras nos metassedimentos e os sistemas de falhas, tanto nos metassedimentos como nos maciços granitóides (para uma apresentação mais detalhada da parte estrutural, ver item 3.5 ).

A evolução dos estudos sobre este tópico, discutida a seguir, é ilustrativa das dificuldades enfrentadas para resolver os problemas relacionados com a origem, 0 metamorfismo e a evolução estrutural destes metassedimentos.

A sequência de rochas metassedimentares encontradas no Domínio São Roque vem sendo objeto de estudos geológicos, estruturais e petrográficos desde fins do século passado (ver bibliografia e discussão em Juliani et al., 1986; Juliani \& Beljavskis, 1995; Juliani, 1993). Inicialmente, foi proposto para este conjunto o nome de "Série da Serra de São Francisco", posteriormente transformado em "camadas São Roque" e, de forma mais definitiva, em "Série de São Roque" (em 1925), que para Moraes Rego (em 1930) era em parte equivalente à "Série de Assunguy", hoje "Açungui", este último nome englobando principalmente as rochas metassedimentares do estado do Paraná; as relações entre estas duas "séries" ou grupos ainda estão sendo discutidas, na literatura local.

Os trabalhos mais recentes, de cunho litoestratigráfico, propõem que o antigo Grupo São Roque seja subdividido, na região central e centro-oriental do Domínio São Roque, em duas unidades que se diferenciariam pelo posicionamento estrutural, pelo padrão de deformação, pelo metamorfismo regional e pela sequência litológica. Esta divisão estabelece como unidade mais antiga o Grupo Serra de Itaberaba e como mais nova o Grupo São Roque.

No Grupo Serra do Itaberaba, predomina uma sequência metavulcano-sedimentar, depositada em ambientes marinhos profundos a intermediários, com proporção significativa de metabasitos e meta-vulcanoclásticas e participação de variado conjunto metassedimentar, tanto meta-clástico (quartzitos, metapelitos) como metassedimentar químico (mármores, sedimentos manganesíferos, itabiritos, rochas cálcio-silicáticas), todo o conjunto afetado por metamorfismo na facies de anfibolito médio e mostrando presença de minerais como granada, cordierita, estaurolita, andaluzita, cianita e fibrolita em litotipos apropriados; a deformação mostra pelo menos 3 planos $S$ diferentes, $o$ inicial $S_{1}$ se ciestacando por apresentar evidências de metamorfismo de pressão elevada (com cianita), enquanto que os restantes desenvolveriam associações metamórficas de menor pressão.

O Grupo São Roque, pelo contrário, estaria principalmente constituído por metassedimentos depositados em ambientes marinhos rasos ("rifts" ensiálicos), constituídos por metapelitos e metarenitos em parte rítmicos, com alguns metaconglomerados e intercalações vulcânicas e vulcanoclásticas, acompanhadas de biohermas e "cálcio-xistos" (mármores de granulação fina), metamorfoseados em fácies xisto verde de baixa pressão, localmente apresentando grau mais alto, em torno de intrusões graníticas; evidências várias sugerem a correlação entre o evento gerador da superficie $S_{1}$ do São Roque com o $S_{2}$ do Serra do Itaberaba (para detalhes, ver Juliani \& Beljavskis, 1995, e literatura citada; ver também item 3.5). Ainda é motivo de discussão a possivel presença de discordância geral entre os dois grupos, embora discordâncias locais foram descritas em algumas regiōes. 
Mapeamentos de detalhe (ver literatura citada) mostram que os dois Grupos podem ser subdivididos com algum grau de confiabilidade. Por enquanto, são identificadas no Grupo Serra do Itaberaba as formações Morro da Pedra Preta, basal, com rochas principalmente metavulcano-sedimentares, e ainda a Nhanguçu, superior, com metapelitos vários, rochas carbonáticas e cálcio-silicáticas, e a Pirucaia, interdigitada com as outras duas, constituida por quartzitos, correspondendo provavelmente à depósitos de borda de bacia. No Grupo São Roque são definidas a Formação Piragibu, basal, metapelítica, a de Pirapora do Bom Jesus, localizada em volta da localidade homônima e que mostra rochas metavulcâncias várias (principalmente basálticas) e biohermas, a da Estrada dos Romeiros, com metapelitos e metarenitos rítmicos, e a Boturuna, superior, com metarenitos predominantes; as formações Pirapora do Bom Jesus e Estrada dos Romeiros estão provavelmente interdigitadas, pelo menos em parte, com a Formação Piragibu (ver Juliani \& Beljavskis, 1995).

Sabe-se ainda pouco sobre as idades do início de deposição dos dois grupos, e das idades dos metamorfismos e deformações correspondentes. As datações difundidas na literatura, escassas, são reproduzidas na Tabela 3.1. Note-se, em primeiro lugar, que o controle de campo das amostras analisadas é em geral precário, em boa parte por falta de afloramentos adequados. Em parte, não foi claramente caracterizada a unidade estratigráfica à qual deve ser atribuida a ocorrência analisada. Os metarcósios (previamente considerados metariolitos ou metariodacitos) estão intercalados com metapsamitos e metaruditos "impuros" e são parte do Grupo Serra do Itaberaba (parte basal?). A idade de zircões (detríticos) desta rocha é de 1790 ( \pm 14 ) Ma (Paleo- a Mesoproterozóico), que deve portanto representar a idade máxima de sedimentação da unidade portadora (parte basal do Grupo Serra do Itaberaba; Juliani et al., 1997). As outras idades relativas ao Grupo citado são as registradas para anfibolitos da Serra do Itaberaba, com uma idade máxima $\mathrm{K} / \mathrm{Ar}$ em rocha total de 1590 ( \pm 150 ) Ma, compatível com o resultado obtido dos zircões. Superposta aos eventos mais antigos, são registradas ainda idades K/Ar e isócronas K/Ar entre 500 e $600 \mathrm{Ma}$ nos mesmos anfibolitos da Serra do Itaberaba (Tabela 3.1), idades também encontradas em rochas do Grupo São Roque e que identificam a atuação de um (ou mais) evento(s) metamórfico(s) do Brasiliano.

Os dados para o Grupo São Roque mostram um panorama confuso. As idades obtidas do metaconglomerado do Jaraguá-Cerro Doce (parte basal do Grupo?) mostram disparidade de dados, possivelmente devidos à desequilíbrios isotópicos. Os seixos, com claros sinais de deformação e alongamento, são de gnaisses granitóides (granitos equigranulares antes da deformação?) e mostram uma isócrona (errócrona?) $\mathrm{Rb} / \mathrm{Sr}$ de $1200( \pm 75) \mathrm{Ma}$, que está em desacordo com a idade isocrónica $\mathrm{Rb} / \mathrm{Sr}$ de $800( \pm 30) \mathrm{Ma}$ obtida da matriz; na mesma rocha, as biotitas (concentradas tanto da matriz como dos seixos) apresentam idade $\mathrm{K} / \mathrm{Ar}$ de $625 \mathrm{Ma}$, registrando assim a possível idade do metamorfismo brasiliano. As idades $\mathrm{K} / \mathrm{Ar}$ de anfibolitos do Pico do Jaraguá, em local vizinho ao dos metaconglomerados, oscilam entre 650 e $500 \mathrm{Ma}$, com três idades variando entre 548 e $554 \mathrm{Ma}$ : com isto, a possível idade do metamorfismo desses metabasaltos ficaria em torno de $550 \mathrm{Ma}$, bastante diferente da presunta idade do metamorfismo dos metaconglomerados. Nestes dados baseia-se a proposta de que o limite inferior para o início da sedimentação do conglomerado (e eventualmente a do Grupo São Roque inteiro) seja o Mesoproterozóico (1200 Ma; e.g., Tassinari, 1988; Juliani et al., 1997), faltando entretanto dados mais consistentes para tais afirmaçōes. 
Tabela 3.1. Idades geocronológicas em rochas dos Grupos São Roque e Serra do Itaberaba.

\begin{tabular}{|c|c|c|c|c|}
\hline Localidade & $\begin{array}{l}\text { Unidade } \\
\text { estratigráfica }\end{array}$ & $\begin{array}{l}\text { Método e material } \\
\text { analisado }\end{array}$ & Datação (Ma) & Observações \\
\hline Pirapora B.J. & $\begin{array}{l}\text { Fm. Pirapora B.J.; } \\
\text { base do Gr.S. } \\
\text { Roque. }\end{array}$ & $\begin{array}{l}\mathrm{K} / \mathrm{Ar} \text {;"pillows", } \\
\text { concentrado de } \\
\text { plagioclásio }\end{array}$ & $\begin{array}{l}1053(96) ; 1652 \\
(121)\end{array}$ & Excesso de ${ }^{40} \mathrm{Ar}$ \\
\hline Morro do Polvilho & Gr.S.Itaberaba & $\begin{array}{l}\text { U-Pb; zircões de } \\
\text { metarcósios (antes: } \\
\text { meta-riodacitos) }\end{array}$ & $\begin{array}{l}1790(14) \\
\text { intercepto sup:; } \\
474(110) \text { interc. } \\
\text { inferior }\end{array}$ & $\begin{array}{l}1790 \text {, idade } \\
\text { máxima da } \\
\text { deposição }\end{array}$ \\
\hline Morro do Polivilho & idem anterior & $\begin{array}{l}\text { Isócrona } \mathrm{Rb} / \mathrm{Sr} \text { em } \\
\text { metarcósios, } \mathrm{RT} \text {. }\end{array}$ & $\sim 550$ & $\begin{array}{l}\text { Alguns pontos não } \\
\text { colineares }\end{array}$ \\
\hline Pico do Jaraguá & $\begin{array}{l}\text { Grupo São Roque } \\
\text { (basal?) }\end{array}$ & $\begin{array}{l}\text { Isócrona } \mathrm{Rb} / \mathrm{Sr} \text { em } \\
\text { seixos de granito- } \\
\text { gnaisse em } \\
\text { metacongl. }\end{array}$ & $1200(75)$ & Seixos deformados \\
\hline Pico do Jaraguá & Idem anterior & $\begin{array}{l}\text { Isocr. } \mathrm{Rb} / \mathrm{Sr} \text { na } \\
\text { matriz, idem } \\
\text { anterior }\end{array}$ & $800(30)$ & $\begin{array}{l}\text { Matriz orientada, } \\
\text { com biot. e musc. }\end{array}$ \\
\hline Pico do Jaraguá & Idem anterior & $\begin{array}{l}\text { K/Ar em biot:; } \\
\text { seixos e matriz, id. } \\
\text { anterior }\end{array}$ & $\begin{array}{l}3 \text { análisis., entre } \\
615 \text { (11) e } 628 \\
(11)\end{array}$ & \\
\hline Pico do Jaraguá & Idem anterior & $\begin{array}{l}\mathrm{K} / \mathrm{Ar} \text {, anfib.; em } \\
\text { anfibolito }\end{array}$ & $\begin{array}{l}500(70) ; 656(54) \\
548(52) ; 554(32) \\
549(56)\end{array}$ & $\begin{array}{l}\text { maioria com exc. } \\
\text { de }{ }^{40} \mathrm{Ar}\end{array}$ \\
\hline Pico do Jaraguá & Idem anterior & $\begin{array}{l}\text { Isócrona } \mathrm{K} / \mathrm{Ar} \text {, } \\
\text { baseada nas idades } \\
\mathrm{K} / \mathrm{Ar} \text {; id.anterior }\end{array}$ & $573(11)$ & \\
\hline Serra Itaberaba & Gr.S.Itaberaba & $\begin{array}{l}\mathrm{K} / \mathrm{Ar} \mathrm{RT} \\
\text { anfibolito }\end{array}$ & $1529(150)$ & \\
\hline S.Itaberaba & Idem anterior & $\begin{array}{l}\text { K/Ar em anfi-bólio; } \\
\text { anfibolito }\end{array}$ & $\begin{array}{l}598(23) ; \quad 530 \\
(30)\end{array}$ & $\begin{array}{l}\text { Discrepância com } \\
\text { idade ant. }\end{array}$ \\
\hline S.Itaberaba & Idem anterior & $\begin{array}{l}\text { Isócrona } \mathrm{K} / \mathrm{Ar} \text {; id. } \\
\text { anterior }\end{array}$ & $\begin{array}{l}515(10)(3 \\
\text { pontos) }\end{array}$ & $\begin{array}{l}\text { Idade resfriam, } \\
\text { intrusão granito } \\
\text { Pedra Branca }\end{array}$ \\
\hline
\end{tabular}

Observaçð̃es: $R T$ : rocha total; (10): erro padrão. Fontes das idades: Tassinari et al. (1985); Van Schmus et al. (1986); Tassinari (1988). Unidades estratigráficas conforme Juliani \& Beljavskis (1995) e Juliani et al. (1997); para identificação dos metarcósios, ver Juliani et al. (1997). 


\subsection{MACIÇOS GRANITÓIDES}

Intrusivos nos metassedimentos ocorrem vários corpos granitóides, considerados de colocação pré-, sin- a tardi- e pós- tectônica. Os mais antigos, pré-tectônicos, localizam-se na parte setentrional do mapa regional (Anexo 1, Figura 3.1). Caracterizamse estes maciços por apresentarem formas alongadas, distribuidos em faixas próximas às principais zonas de cisalhamento; estão, normalmente, intensamente deformados por efeito das sucessivas etapas de deformação. Os granitóides considerados sin- a tarditectônicos são de idade brasiliana e aparecem distribuidos, em parte como maciços maiores, por toda a região citada; aparecem cortados por inúmeras falhas, conı alguns sinais de deformação localizadas (como faixas cisalhadas, etc.). Tanto os maciços prétectônicos como os de filiação brasiliana apresentam biotita granitos, em bọa parte porfiríticos, como litotipos predominantes; alguns maciços (ou fácies mais evoluidas de maciços maiores) são constituidos por granitos a duas micas, tipicamente também com alguma granada, e por turmalina granitos.

\subsubsection{Granitóides pré-tectônicos}

Os maciços considerados pré-tectônicos, por apresentarem em geral forte deformação (Dantas, 1990), são os seguintes: Barroca Funda, Francisco Morato, Vargem Grande, Mato Dentro, Pedra Vermelha e Vila dos Remédios (ver localização no Anexo 1 e Figura 3.1), descritos a seguir, com informações extraidas do trabalho de Dantas (1990).

O maciço da Barroca Funda, localizado no extremo NW do mapa regional, apresenta forma lenticular de orientação $\mathrm{E}-\mathrm{W}$, medindo aproximadamente $2,5 \mathrm{~km}$ de comprimento por $500 \mathrm{~m}$ de largura, com área total da ordem de $1,2 \mathrm{Km}^{2}$. Constitui-se de biotita monzogranito porfiróide de cor cinza esverdeada, com megacristais de microclínio esbranquiçado, apresentando textura porfiroclástica blastomilonítica, que grada para a granular hipidiomórfica nas regiões não ou pouco deformadas. É notada ainda a ocorrência de enclaves micáceos e microgranulares (hornblenda-quartzo dioritos), estirados e orientados.

O maciço de Francisco Morato é composto por vários corpos lenticulares descontínuos, com largura máxima de $300 \mathrm{~m}$, que afloram por $5 \mathrm{~km}$ desde os arredores de Francisco Morato até o ribeirão Patara. As rochas constitutivas são leuco-monzogranitos a leuco-sienogranitos a duas micas, de granulação grossa a média, dominantemente inequigranulares, com variedades porfiríticas restritas às bordas. A estrutura da rocha é gnaíssica difusa a gnáissica bandada, a última mais restrita. Os principais minerais são plagioclásio, quartzo (em agregados granoblásticos finos) e microclínio; acompanha muscovita, frequentemente deformada, e secundariamente biotita. Como minerais acessórios ocorrem opacos, epidoto, apatita e allanita.

O maciço Vargem Grande é um corpo lenticular medindo $350 \mathrm{~m}$ de largura máxima por $5 \mathrm{~km}$ de comprimento, com área total da ordem de $1,5 \mathrm{Km}^{2}$, localizado próximo à falha do Lago Azul. A rocha apresenta textura inequigranular a porfirítica com desenvolvimento de estruturas gnaíssicas nas bordas; aparecem também bandas mais deformadas, com passagens para protomilonitos, milonitos e ultramilonitos. A composição predominante é monzogranítica com variações para leucotonalitos. $O$ quartzo 
apresenta-se quase totalmente recristalizado, formando ribbons alongados; o plagioclásio é levemente arredondado e o microclínio xenomórfico. A biotita ocorre em pouca quantidade, com muscovita e clorita preenchendo planos de fraturas. Como minerais acessórios tem-se opacos, zircão e allanita.

O maciço do Mato Dentro é representado por uma pequeno corpo irregular a alongado, com 1,6 km de comprimento e $500 \mathrm{~m}$ de largura, localizado ao sul do ribeirão Itaim, entre as falhas do Lago Azul e dos Remédios. A rocha, maciça a foliada e de cor cinza, apresenta composição monzogranítica, e textura porfiroclástica a inequigranular, raramente porfiróide; veios e bolsões de composição quartzo-feldspática são frequentes. A mineralogia principal é constituída por plagioclásio (oligoclásio) xenomórfico, microclínio subdiomórfico e quartzo como agregados granoblásticos finos e ribbons alongados. Como minerais máficos ocorrem muscovita e biotita e como minerais acessórios opacos limonitizados, turmalina, titanita, zircão e allanita.

O maciço da Pedra Vermelha, localizado a NE do granitóide Mairiporâ, constitui corpo alongado, com largura máxima de $750 \mathrm{~m}$, estendendo-se por aproximadamente 4 $\mathrm{km}$ rumo a ENE. O contato com a rocha encaixante é discordante e tectônica. As rochas predominantes são de composição monzogranítica a sienogranítica, a duas micas, leucocrático, com texturas de granulação média a grossa, porfiroclásticas a miloníticas nas bordas passando para inequigranulares no centro. A mineralogia principal é formada por plagioclásio, microclínio e quartzo dispersos como agregados granoblásticos. A biotita apresenta cor marrom. Como acessórios ocorrem minerais opacos, zircão e turmalina.

O maciço Vila dos Remédios, localizado no extremo NE do mapa regional, imediatamente à NE do granitóide Mairiporâ, constitui o maior destes corpos prétectônicos (com aproximadamente $12 \mathrm{~km}$ de comprimento e $950 \mathrm{~m}$ de largura máxima, com área total que ultrapassa os $10 \mathrm{Km}^{2}$ ); aparece inteiramente limitado por falhas. As rochas constituentes estão bastante deformadas nas bordas, onde desenvolvem estruturas do tipo augengnaisse. A deformação diminue para o centro, onde estão preservados termos mais maciços. Constituem-se de biotita sienogranitos com variações para quartzo sienitos, inequigranulares e de granulação grossa quando não deformados. Os minerais principais são microclínio, piagioclásio e quartzo, este último como agregados granoblásticos.

É completamente desconhecido o posicionamento estratigráfico destes granitóides, já que não existem dados sobre as suas idades e as possíveis relações genéticas, tanto entre si como frente aos granitóides brasilianos, considerados posteriores. Os maciços que mostram contatos intrusivos são evidentemente posteriores aos metassedimentos encaixantes, uma conclusão que também é aplicada por Dantas (1990) para aqueles maciços com relações indefinidas de contato, por serem estes tectônicos (maciços de Pedra Vermelha e Vila dos Remédios). Mas a falta de dados não exclui a possibilidade de que alguns representem rochas do embasamento dos metassedimentos. Alternativamente, eles podem ser em parte os equivalentes deformados (sintectônicos?) de alguns dos maciços brasilianos, haja visto as semelhanças mineralógicas entre os granitóides de Perus e Tíco-Tico com alguns dos granitóides "pré-tectônicos"a duas micas e com turmalina, tais como os dos maciços Francisco Morato, da Pedra Vermelha e do Mato Dentro, ou a presença de enclaves no biotita granito de Barroca Funda, sugerindo tratar-se de 
ocorrência evoluida apartir de magmas iniciais de filiação cálcio-alcalina (e, portanto, também brasiliana?).

\subsubsection{Granitóides brasilianos}

Os granitóides considerados brasilianos foram, anteriormente, classificados em função de suas feições características e subdivididos, com tal base, em sin-, tardi- e póstectônicos, como citado em publicações anteriores (e.g., Hasui et al., 1978; Carneiro, 1983; Dantas, 1990; ver também bibliografia na compilação de Janasi \& Ulbrich, 1992). São encontrados desde maciços de dimensões menores ou médias, até aqueles que constituem as maiores unidades granitóides presentes na região. Entre os primeiros, são citados os vários granitóides coletivamente denominados de "turmalina granitos" ou de "Granitos Perus" (ou "Granito Perus"), claramente muito diferenciados e de colocação possivelmente muito rasa. As ocorrências de dimensões intermediárias são os maciços Tíco-Tico (à duas micas e granada), Mairiporã (com biotita como máfico principal ou único), Itaim (limitado por fraturas), Ponunduva (fortemente cataclasado e alterado) e Taipas (com biotita e anfibólio); o maciço de Ponunduva aflora apenas em parte na região considerada, na sua porção mais ocidental, e não está representado no mapa do Anexo 1. Os de maiores dimensões são os batólitos Itaqui e Cantareira, que em parte se expandem também para as folhas vizinhas, mais para S (ver Anexo 1, Figura 3.1).

As feições mineralógico-petrográficas e geoquímicas mostram que estes granitóides pertencem à linhagens muito diferentes. São encontrados os com características claramente, ou marginalmente, cálcio-alcalinas (e.g., os maciços Taipas e Cantareira, e as facies mais importantes do maciço Itaqui) até os de derivação crustal (e.g., o maciço Tico-Tico e as fácies mais evoluidas do Itaquí, e até alguns dos que são considerados por alguns autores como de natureza pré-tectônica, tais com os de Mato Dentro, Pedra Vermelha e Francisco Morato). Notáveis, embora constituam ocorrências muito restritas, são as bossas e os diques altamente diferenciados que formam o conjunto dos granitóides de Perus e alguns dos litotipos de menor expressão do Itaquí, todos com turmalina (e granada) como máfico(s) único(s), e cujos elevados teores de $\mathrm{Li}, \mathrm{U}$ e outros elementos permitem a cristalização de micas de $\mathrm{Li}$ e minerais tardios de $\mathrm{U}$.

Datações geocronológicas U-Pb mais recentes, principalmente em zircão, mostram idades coincidentes para muitas destas manifestações (Itaqui, $624 \pm 11 \mathrm{Ma}$ para a sua fácies Barueri; Tico-Tico, $625 \pm 18 \mathrm{Ma}$; Cantareira, $630 \pm 8 \mathrm{Ma}$; ver Tabela $2.2 \mathrm{e}$ comentários no item 2.3.3), forçando a uma reavaliação das sugestões apresentadas previamente na literatura sobre esta região. Assim, a proximidade geográfica entre estes maciços graníticos, todos situados no Domínio São Roque e com relações claramente intrusivas frente aos metassedimentos ali encontrados, mostra que eles não mais deveriam ser classificados como maciços sin-, ou tardi- ou pós-tectônicos, tão somente em função da forma e elongação, presença de estruturas internas, texturas porfiríticas ou mais equigranulares, e caráter mais ou menos "cálcio-alcalino".

Uma avaliação mais objetiva deve apresentar um panorama geológico que compatibilize tanto as observações sobre geologia e mineralogia-petrografia destes corpos com também as datações mais recentes. 
As principais feições mostradas por estes granitóides são descritas a seguir, principalmente em função de dados apresentados na literatura.

O maciço Itaqui foi mapeado em detalhe por Ferreira (1991), que mostrou ser ele constituído por variado conjunto de intrusões sucessivas, que o considera um "complexo" composto, com facies cálcio-alcalinas predominantes. Mostra forma triangular, alongado no sentido WNW-ESE, com superficie exposta da ordem de $120 \mathrm{Km}^{2}$, e que no seu limite meridional aparece em contato com a zona de cisalhamento Taxaquara. Nele foram identificadas dez fácies diferentes, que ascenderam durante quatro pulsos magmáticos relacionados a dois episódios ou "ciclos" intrusivos diferentes.

Os primeiros pulsos ou acrescões são de rochas granitóides com textura porfiritica, constituindo o granodiorito Barueri e o monzogranito Pedreira Cantareira, com biotita e hornblenda. Culmina esta fase com a intrusão dos diques do biotita monzogranito Torre, equigranular de granulação fina, os diques máficos de monzogranito porfiróide e equigranular com biotita e hornblenda, e os diques de quartzo monzonito Cruz Preta, porfirítico e com biotita, marcam a primeira fase de acresção. Os biotita monzogranitos Aldeia da Serra e Mutinga, que mostram textura inequigranular serial a porfirítica, representariam a terceira fase de acresção. A última fase estaria representada pela invasão de corpos menores, os diques monzograníticos Suru, equigranulares e com biotita, e os aplitos com turmalina e sericita. Considera Ferreira (1991) que a intrusão principal ocorreu entre a segunda e a terceira fase de deformação regional nos metassedimentos do Domínio São Roque, sendo ainda duvidoso o posicionamento dos aplitos com turmalina (ver também Ferreira, 1997; Wernick et al., 1993a, 1993b, 1993c, 1995).

O maciço ou "Complexo" Cantareira é uma das maiores manifestações granitóides encontradas no estado, mostrando complexa faciologia e estrutura interna. Têm forma alongada segundo direção NE-SW, com superficie aflorante da ordem de 320 $\mathrm{Km}^{2}$. Os contatos são tectônicos, estando limitado por falhas vizinhas à de Caieiras (parte setentrional) e pela zona de cisalhamento de Mandaquí (região ocidental).

Dantas (1990) reconheceu neste maciço nove fácies ou "tipos" distintos. A fácies ou tipo Pirituba (fácies porfiróide creme) é de biotita granodioritos a monzogranitos porfiróides, com rara hornblenda mas rica em enclaves; mostra fenocristais bege de microclínio, sem orientação, sendo predominante no centro e SE do maciço. O tipo Canivete (fácies porfiróide cinza azulada) é composto principalmente por monzogranitos porfiróides, com megacristais não orientados de microclínio cinzas e abundantes enclaves microgranulares, predominando na parte SW do maciço. O tipo Itaguassu (fácies porfiróide rósea), é caracterizado por bolsões de monzogranitos a granodioritos porfiróides; são comuns os enclaves micáceos e os sulfetos em fraturas. O tipo Mandaqui (fácies ortognáissica ) mostra composição granodiorítica a monzogranítica porfiróide, com megacristais arredondados localizados em matriz deformada milonítica a blastomilonítica, aparecendo principalmente nas margens do corpo e em zonas de falha. $\mathrm{O}$ tipo Tremembé (fácies equigranular cinza) aparece como bolsões irregulares e diques métricos, dispersos por todo o maciço; são monzogranitos de cor cinza claro, equigranulares e com enclaves, e posteriores ao tipo Pirituba. O tipo Petrópolis (fácies pegmatóide), que ocorre como bolsóes irregulares, constitui-se de granodioritos a 
monzogranitos porfiróides ricos em megacristais; são encontrados enclaves microgranulares e micáceos. O tipo Hortolândia (fácies inequigranular cinza) é de monzogranitos a granodioritos inequigranulares de cor cinza, orientados e com enclaves, que aparecem como corpos alongados nas margens NE do maciço mostrando gradacções para os tipos porfiróides por aumento nos teores de fenocristais. A facies Santa Inês (fácies migmatítica ou bandada) é de granodioritos porfiróides, ricos em biotita e com clara estrutura de fluxo (aspecto "bandado" da rocha), encontrados como fácies da borda $\mathrm{N}$ do maciço. Finalmente, o tipo Jaraguá (fácies inequigranular leucocrática) é formado por bolsões irregulares e diques métricos de leuco-quartzo monzonitos esbranquiçados, mostrando em partes forte alteração hidrotermal. Estas fácies teriam se colocado em função de 4 pulsos magmáticos (Wernick, 1993). Dantas (1990) indica que a colocação deste batólito é sincrônica à fase D2 de deformação das rocha encaixantes, ou algo posterior.

O macico Mairiporâ localiza-se a NW da cidade homônima, apresentancio forma elipsoidal, com extremidades achatadas, orientado segundo direção NE-SW e superficie de $37 \mathrm{Km}^{2}$. Segundo Dantas (1990), as fácies que compõem o maciço são predominantemente porfiróides, com estruturas maciças que nas bordas passam levemente foliadas, porem em geral com menos megacristais e mais biotita que os granitóides do maciço Cantareira. Predominam no maciço os biotita granodioritos, com variações para monzogranitos, e raros monzodioritos; a hornblenda está ausente, e os minerais acessórios são titanita, apatita, allanita, e opacos (titano-magnetita, ilmenita e sulfetos). Na sua porção central ocorre largamente o tipo Mairiporâ (fácies porfiróide a inequigranular cinza, 25\% do corpo), representado por rochas inequigranulares a pouco porfiróides, de composição granodiorítica a monzogranítica, de cor cinza, com poucos megacristais de ate $8 \mathrm{~cm}$, e o tipo Pirituba (50\% do corpo, similar ao de nome equivalente encontrado no maciço Cantareira). Em menores proporções, são encontrados no seu interior o tipo Tremenbé e nas bordas os tipos Canivete, Mandaqui e Santa Inês (ver descrições no maciço Cantareira). A sua colocação seria sincrônica, ou algo posterior, à fase D2 de deformação (Dantas, 1990).

O maciço Taipas localiza-se imediatamente à oeste do Granito Cantareira, apresentando afloramentos discontínuos, rodeados por metassedimentos; destacam-se, principalmente, três áreas ou bossas mais características, como identificado por mapeamento de revisão realizado para este trabalho (ver maiores detalhes no mapa do Anexo 2 e Captítulo 4, sobre Geologia local). A área total é de poucos $\mathrm{Km}^{2}$. Dantas (1990) reune estes afloramentos isolados numa única ocorrência de $5 \mathrm{Km}^{2}$, integrada principalmente por fácies do tipo Pirituba (75\%), acrescido nas suas porções norte e sul pelos tipos Hortolândia (10\%) e Itaguassu (5\%) (ver descriç̋es no Granito Cantareira, acima). De maneira geral, as rochas apresentam textura porfiróide, de matriz media a grossa, e composição monzogranítica variando para termos granodioríticos, tonalíticos e mais raramente monzodioritos, estes restritos às bordas. A biotita (11\%) apresenta-se como máfico principal, seguido de hornblenda; os minerais acessórios são titanita, apatita e opacos (sulfetos, ilmenita e titano-magnetita), ocorrendo ainda zircão, allanita e turmalina. O mesmo autor refere-se a existência de uma aureola irregular de contato, marcada por feldspatização, turmalinização e recristalização de filossilicatos nas rochas encaixantes. 
O maciço Itaim apresenta-se limitado por fraturas, com formato ovalado, com eixo maior orientado na direção N-S, localizado entre os Maciços Tico-Tico e Itaqui. Coutinho (1972) identifica como fácies predominante o tipo Pirituba, com coloração cinza claro a cinza médio, porfiróide com megacristais de feldspato potássico róseo a branco, numa matriz inequigranular de granulação media a grossa.

O pequeno maciço Morro de Perús (forma elipsoidal, superficie de $0,3 \mathrm{Km}^{2}$ ) localiza-se à norte da estrada Di Sandro. A sua composição varia de monzogranito a sienogranito, apresentado biotita, e como minerais acessórios granada, apatita, titanita, zircão e opacos. De faciologia variada, seriam reconhecidos neste corpo tipos porfiróides na borda, e rochas mais equigranulares no centro (Dantas, 1990). Ocorrem a fácies porfiróide creme (tipo Pirituba?), que ocorre na porção sudeste do corpo (granodioritos com matriz inequigranular media a grossa, cinza clara, e concentração de sulfetos ao longo de planos de fraturas), a fácies inequigranular mosqueada (leucomonzogranitos de granulação grossa), a fácies inequigranular leucocrática (similares ao tipo Jaraguá; leucomonzogranitos de cor cinza clara a esbranquiçada, granulação fina a media, sem biotita e com granadas submilimétricas) e a fácies aplítica, com sulfetos disseminados e cortada por diques de granitóides e pegmatóides com turmalina; as duas últimas fácies ocorrem sob forma de bolsões.

O maciço do Juqueri, localizado no município de Franco da Rocha, próximo ao Hospital Psiquiátrico do Juqueri, mostra-se com forma levemente triangular e superficie de cerca de $1,4 \mathrm{~km}^{2}$. Apresenta as bordas deformadas com desenvolvimento de estruturas orientadas e cataclasadas, e região interna mais isótropa. Segundo Dantas (1990), a rocha mostra textura inequigranular de granulação fina a média, cor cinza clara. Sua composição petrográfica dominante é a de biotita monzogranito, orientados e cataclasados nas bordas, mais maciços no centro do corpo. Os minerais acessórios são opacos, allanita e apatita, e os secundários epidoto, clorita e sericita.

O maciço Tico-Tico (Moraes Rego, 1933b) ou Anhanguera (Penalva \& Hasui, 1970), constitui uma elevação topográfica de forma elipsoidal à NW da vila de Perus, com aproximadamente $11 \mathrm{~km}^{2}$ de superficie, orientada segundo direção W-E. Segundo Carneiro (1983), a rocha predominante apresenta granulação media a grossa, geralmente inequigranular, cor cinza clara com variaçðes para bege, creme e avermelha. São sieno- a monzogranitos com biotita e muscovita; granada, turmalina e zircão são os minerais acessórios. Observa-se em partes uma tênue foliação pela orientação dos cristais de biotita, que tende a aumentar da borda para o centro do maciço. Associados espacialmente ao granito Tico-Tico ocorrem ainda uma série de veios pegmatóides dobrados de composição granítica, com as suas porções centrais enriquecidas em turmalina e filmes marginais com muscovita, na interface com as rochas encaixantes.

\subsection{COBERTURA RECENTE}

A cobertura recente é formada por depósitos colúvio-eluvionares e aluvionares. Os primeiros distribuem-se por toda área sendo constituído de material amarelo avermelhado, inconsolidado, de amplo espectro granulométrico, argiloso a arenoso, por vezes também com matacões e blocos.; muitas vezes portam stone lines, as estreitas linhas continuas de 
seixos e blocos no colúvio que acompanham a topografia, frequentemente separando o material inconsolidado da rocha alterada infrajacente.

Os depósitos aluvionares são restritos às calhas dos rios da rede hidrográfica e de suas planícies adjacentes temporariamente inundadas (várzeas). Nos canais principais $\mathrm{e}$ seus afluentes, são depositados materiais arenosos a areno-argilosos, e nas planícies de inundação são encontrados sedimentos mais sílticos-argilosos; ambos apresentam coloração variando entre cinza escuro, bege e amarelo. Estes tipos de depósitos normalmente ocorrem em pequena proporção, muitas vezes não sendo possivel seu mapeamento em escala regional; são algo mais extensos nos locais em que se formaram as planícies de inundação.

\subsection{ASPECTOS ESTRUTURAIS}

Além de acentuadas variações nos litotipos dominantes, tem-se ainda diferenças na historia deformacional dos pacotes litológicos posicionados no mapa regional de compilação (Anexo 1).

$\mathrm{Na}$ porção ocidental do mapa regional (Anexo 1), são reconhecidos nos metassedimentos cinco fases deformacionais superpostas, sendo as três primeiras de natureza sin- a tardi- metamórfica enquanto que as outras outras duas são posteriores ao pico do metamorfismo (Bergmam, 1988).

Para a primeira fase não foi identificado nenhum tipo de dobras, mas sim uma discreta clivagem ardosiana paralela ao acamamento reliquiar. A segunda fase, amplamente difundida neste domínio, manifesta-se nos metassedimentos através de dobras isoclinais recumbentes, com o plano de foliação S2 caracterizado por uma clivagem de transposição que frequentemente desenvolve bandamento sub-milimétrico. A terceira fase, tardia ao principal evento metamórfico, foi impressa através de dobras simétricas, com clivagem plano-axial S3 do tipo clivagem de fratura, desenvolvendo ainda dobras abertas e normais. As duas últimas fases deformacionais foram inferidas através de tratamento estatistico dos dados.

Para as porções central e oriental do mapa regional (Anexo 1), tanto Carneiro (1983) como Dantas (1990) reconhecem cinco fases de deformação superpostas.

A fase deformacional mais precoce desenvolveu uma foliação, $\mathrm{S} 1$, do tipo clivagem ardosiana ou xistosidade, definida pela orientação principalamente de filossilicatos. Esta foliação encontra-se em posição plano-axial em dobras fechadas a cerradas, do tipo isoclinal, com dimensð̃es variadas. A segunda fase, responsável pelas maiores estruturas dobradas, apresenta uma clivagem de crenulação, S2, melhor desenvolvida em litotipos de granulação mais finos (e.g., filitos), evoluindo para clivagem de fratura nos litotipos mais grosseiros (e.g., quartzitos laminados, rochas calciossilicáticas e micaxistos). A superfície S2 é plano-axial nas dobras D2, do tipo aberto a fechado, com dimensões centimétricas a decamétricas. As fases deformacionais posteriores são manifestadas de maneira mais tênue, sendo responsáveis pela impressão de ondulações e virgação nas estruturas preexistentes. A terceira fase apresenta dobras D3 
abertas a suaves, de dimensões variadas, com foliação $\mathrm{S} 3$ em posição planomaxial e representada por clivagem ardosiana ou clivagem de fratura. A quarta fase é mais restrita, e sua ocorrência geográfica, próxima aos corpos granitóides, sugere uma relação genética com os mecanismos de colocação das rochas granitóides.

O desenvolvimento das grandes zonas de cisalhamento, que configuram o arcabouço estrutural observado hoje, se deu em paralelo às várias fases deformacionais citadas, mas com uma evolução tardia marcada, como comprovado pelo fato de que todos os corpos granitóides estão fortemente afetados por zonas, apresentando-se ainda faixas características de milonitos e blastomilonitos, cortando tanto os maciços granitóides quanto as rochas enciaxantes metamórficas. A instalação das principais zonas de cisalhamento Jundiuvira, Caieiras, Buquira e Taxaquara iniciou-se provavelmente durante o ápice do metamorfismo, na segunda fase deformacional, com progressão do cisalhamento até etapas posteriores à colocação e resfriamento dos granitos brasilianos. 


\section{CAPÍTULO 4}

\section{GEOLOGIA LOCAL}

A área com afloramentos dos turmalina granitos de Perus é de aproximadamente $1,1 \mathrm{Km}^{2}$ (1400 $\mathrm{m}$ por $800 \mathrm{~m}$ ), circundada pela rede local de drenagem. Ela foi mapeada em maior detalhe pelo autor, com a dupla finalidade de identificar o número e a exitensão das ocorrências citadas e de esclarecer, se possível, as relações destes turmalina granitos com os outros granitóides das vizinhanças (maciços Taipas e Cantareira e a ocorrência Morro do Perus). O mapeamento foi realizado com a utilização das folhas topográficas em escala 1:10.000 da EMPLASA Morro do Tico-Tico, Pico do Jaraguá, Perús e Jardim Panamericano (ver item 1.4.2). Este mapeamento considerou também, embora de maneira superficial e sem maiores detalhes, a litologia das rochas metassedimentares encaixantes e as suas estruturas (foliações, algumas das dobras presentes). Foram adicionalmente identificados os sistemas de juntas e as zonas de cisalhamento, visíveis principalmente quando afetam os granitos; em alguns casos, a continuação das zonas de cisalhamento nas rochas encaixantes pode ser observada pela presença de estruturas ad-hoc, principalmente pela verticalização local das foliações e/ou a presença de estruturas lineares subhorizontais (lineações minerais). Os resultados deste mapeamento são mostrados no Anexo 2 (em escala 1:5.000; encarte) e em escala mais reduzida na Figura 4.1.

As unidades mapeadas representadas no Anexo 2 são principalmente de dois tipos: as rochas encaixantes metassedimentares atribuídas ao Grupo Serra do Itaberaba (?), provavelmente do Paleo- ou Mesoproterozóico, e os granitóides brasilianos do Neoproterozóico, compreendendo os maciços Cantareira e Taipas, a pequena bossa do Morro do Perus e as várias ocorrências do turmalino granito de Perus. Depósitos colúvioaluvionares aparecem nas encostas dos morros e, em pequena proporção, depositados nas pouco expressivas várzeas da rede local de drenagem; não são discutidos aqui, por apresentar-se como volumes pequenos.

\subsection{AS ROCHAS METASSEDIMENTARES DO GRUPO SERRA DO ITABERABA}

Estas rochas são as encaixantes dos granitos acima citados. Predominam entre estas principalmente xistos de granulação fina a média, com afloramentos, em geral muito alterados, visíveis tão somente em pedreiras, cortes de estrada e ao longo de trilhas abertas por moradores. As cores são marrom escuro a avermelhado, dependendo do grau de alteração; as amostras frescas, mostram tons cinzentos a esverdeados. As estruturas são fortemente foliadas, com desenvolvimento de textura lepidoblástica, por vez com pequenos porfiroblastos milimétricos de granada avermelhada e com manchas esbranquiçadas formadas por mosaicos de quartzo; a associação mineral observada é quartzo, biotita, sillimanita, muscovita e granada. 


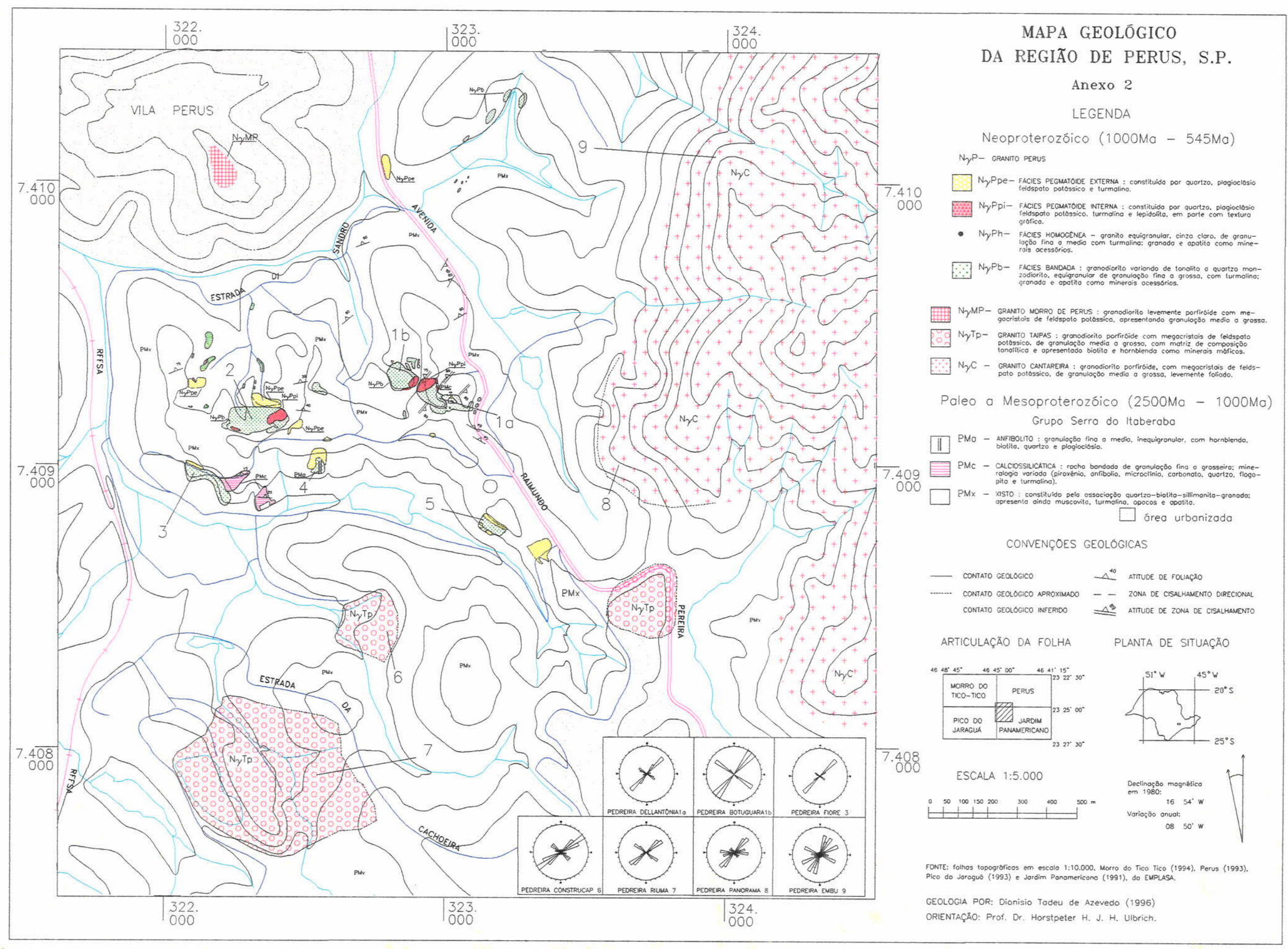


Nos afloramentos frescos em pedreiras, é observado também marcado bandamento, correspondendo ao acamamento original, em geral perfeitamente visível; nestes casos, verifica-se que os níveis ricos com minerais micáceos (biotita e muscovita), ou seja, os constituídos por xistos, são de espessura milimétrica a centimétrica, alternando-se com outros mais maciços e menos ricos em micas, representando as camadas originalmente mais arenosas. Em alguns casos, são observados níveis mais grafitosos e ricos em muscovita.

Como intercalações com forma de lentes, de distribuição muito irregular, são encontradas frequentemente rochas calciossilicáticas bandadas, cinzento-esverdeadas e de granulação fina a muito fina. Bandas mais cinzentas alternam com outras mais esverdeadas, com espessuras bastante regulares, milimétricas a centimétricas; as texturas são granoblásticas, sem orientação. As melhores exposições destas rochas são encontradas em áreas de mineração de pedreiras. $\mathrm{O}$ maior destes corpos aparece na vizinhança do corpo 3 (pontos 156 e 157, Anexos 2 e 3) como duas grandes lentes, a maior medindo 80 $\mathrm{m}$ de comprimento por $70 \mathrm{~m}$ de espessura, que se destaca no mapa local (Anexo 2); outro corpo claramente visível é encontrado em contato com o granito da pedreira Dellantônia (corpo 1a; ponto 31; ocorrência não registrada em mapa). Ao microscópio, observa-se uma associação de diopsídio, tremolita, flogopita, microclínio e plagioclásio, como minerais essenciais, e outros vários como fases acessórias (e.g., opacos, vesuvianita, escapolita, granadas, etc.); quartzo ou calcita, em geral, estão ausentes ou presentes em quantidades subordinadas (Cordani et al., 1963; ver também Capítulo 5).

Intercalações de anfibolitos são encontradas em vários lugares (e.g., na região do corpo 4; ponto 155, Anexos 2 e 3). As rochas são de cor preto-esverdeada (quando frescas) a avermelhada; solos formados sobre anfibolitos mostram uma coloração esverdeada muito característica. As estruturas são foliadas, em geral equigranulares e homogêneas (não bandadas), com anfibólio como mineral predominante.

As rochas metassedimentares desta região foram descritas, em publicações anteriores, como integrantes do Grupo São Roque (e.g., IPT, 1981; Coutinho, 1980; Carneiro, 1983; Dantas, 1990). Em trabalho mais recente, Juliani (1993, e bibliografia ali citada) estas são atribuidas ao Grupo Serra do Itaberaba (ver também comentários no item 3.2). A idade mais provável conferida à deposição inicial do Grupo é fím do Paleoproterozóico ou início do Mesoproterozóico (ver Tabela 3.1 e discussão no item 3.2).

\subsection{OS GRANITÓIDES BRASILIANOS}

Todos os granitóides localizados na região do Anexo 2 são considerados brasilianos. São eles o maciço ou batólito Cantareira, o maciço Taipas, a pequena ocorrência do Morro do Perus, e os turmalina granitos que constituem, coletivamente, os "turmalina granitos de Perus". 


\subsubsection{O Granito Cantareira}

É o maior corpo da região (Anexo 2), aflorando nela apenas a sua porção mais ocidental (ver extensão do maciço no Anexo 1). Responsável pela aparição de marcado alto topográfico, é encontrado principalmente como matacões de diversos tamanhos, geralmente de dimensões métricas, mais raramente como afloramentos ou lajedos. $\mathrm{Na}$ maioria destes matacões já e observada alteração moderada ou até avançada, pelo menos na sua casca mais externa, principalmente por caolinização dos feldspatos; em cortes de estrada e de trilhas, aparece o granito convertido em material inconsolidado regolítico, destacando-se nele como característicos os grãos de quartzo entre os argilominerais de alteração. O solo de origem granítica é de cor marrom clara a marrom ferrugem, podendo ser observados por vezes grãos de quartzo residual. Amostras frescas foram obtidas na porção SW, nas duas pedreiras Panorama e Embu, cada uma delas com produção considerável de pedra britada (ver localização no Anexo 2; Foto 4.1). Em ambas ocorrem claros sinais da atuação de regime compressivo, com desenvolvimento de zonas de cisalhamento.

A rocha apresenta cor cinza clara, com um índice de coloração em torno de 6 6, e textura porfirítica com fenocristais de feldspato potássico cinza escuros a esbranquiçados, tabulares a equidimensionais, que não excedem os $3 \mathrm{~cm}$ de comprimento. A matriz é inequigranular, média-grossa, com plagioclásio esbranquiçado e feldspato potássico cinzento, ambos tabulares, quartzo irregular a equidimensional, e agregados alongados de minerais máficos, entre os quais predomina a biotita. A estrutura da rocha é maciça a levemente orientada, por orientação incipiente dos agregados máficos e das biotitas.

Idade. A idade do maciço Cantareira, ou pelo menos de suas variedades porfíríticas dominantes, é de $630 \pm 8 \mathrm{Ma}$ (Töpfner, 1996; ver item 3.4 e Tabela 3.2). Esta idade corresponde, como proposto em trabalhos anteriores, aquela que definiria a colocação dos granitóides considerados "sin-tectônicos".

\subsubsection{O Granito Taipas}

Em trabalhos anteriores, o Granito Taipas foi identificado, em mapa, como uma ocorrência única, com superfície aflorante da ordem de alguns $\mathrm{Km}^{2}$ (e.g., Dantas, 1990). Ele aparece, na realidade, como três "stocks" independentes, de dimensões reduzidas, e algumas manifestações aparentemente menores, identificadas no terreno pela aparição de matacões isolados (Anexo 2, Figura 4.1); a maior destas ocorrências aflora em área de aproximadamente $0,25 \mathrm{Km}^{2}$. Entre estas bossas, são encontrados afloramentos de xistos encaixantes, como é possível observar tanto em cortes de estrada como pela coloração do solo e regolito, o último ainda com estruturas foliadas preservadas. Duas pedreiras de grande porte estão no momento explorando pedra britada (pedreira Construcap no Taipas, número 6; pedreira Riuma, número 7; Anexo 2 e Figura 4.1). Estas rochas mostram-se afetadas por zonas de cisalhamento.

As rochas que constituem estes três "stocks" são muito parecidas entre si. Apresentam aspecto maciço, de cor cinzenta, com índice $M$ em torno de 8 a 9 . A textura é porfirítica, com megacristais de cor róseo-bege a cinza claro de feldspatos potássicos tabulares (até $3,5 \mathrm{~cm}$ de comprimento) e matriz média a grossa, com plagioclásio 
esbranquiçado e feldspato bege, tabulares a irregulares, e ainda quartzo e agregados máficos alongados a irregulares (até $1 \mathrm{~cm}$ ) com biotita laminar e minerais acessórios. A presença esporádica de anfibólio, ao microscópio, indica que se trata de um granitóide de natureza cálcio-alcalina; possivelmente, é um dos representantes cálcio-alcalinos da "associação Cantareira", definida por Janasi \& Ulbrich (1991).

Idade. Existe apenas uma idade K-Ar em biotita de 540 Ma para esta granito (Cordani \& Bittencourt, 1967). Com este dado, que de todas maneiras identificaria a idade do fechamento do sistema K-Ar, o granitóide seria classificado como "pós-tectônico", pelos critérios expostos em trabalhos anteriores. Entretanto, a mineralogia denota claramente a tendência cálcio-alcalina destas rochas, representando então tipos menos evoluídos, eventualmente até associadas ao magmatismo que originou o batólito Cantareira. A idade, neste caso, deveria ser superior aos $600 \mathrm{Ma}$, a julgar pelas datações mais definitivas hoje divulgadas na literatura (ver discussão no item 2.3, sobre granitóides do estado de São Paulo).

\subsubsection{O granito Morro do Perus}

De ocorrência muito restrita, aparece como alguns matacões localizados no alto do Morro homônimo, em área urbanizada (Foto 4.2). Esta ocorrência teria uma extensão de até $300 \mathrm{~m}$, e nela ocorreriam desde fácies porfiróides (do "tipo Pirituba") até mais equigranulares, como citado em referências anteriores (e.g., Dantas, 1990; ver Capítulo 3); estas observações não podem ser verificadas, hoje, por avanço do espaço urbano. A rocha, parecida aos tipos que afloram no maciço Cantareira, é porfirítica de cor cinzenta, com megacristais de feldspato potássico cinza claro, em matriz média-grossa com feldspato potássico, plagioclásio esbranquiçado, quartzo e agregados máficos alongados com biotita.

Idade. Não existem dados geocronológicos sobre esta ocorrência. As fácies porfiróides do Morro do Perus descritas na literatura seriam similares às encontradas no maciço Cantareira (portanto, com idades de $>600 \mathrm{Ma}$ ), enquanto que a mineralogia presente nas fácies mais evoluidas (granada em aplitos, turmalina em diques tardios; cf. Dantas, 1990; ver também Capítulo 3), as identificaria como de colocação mais recente (< $600 \mathrm{Ma}$ ?), possivelmente relacionadas com os turmalina granitos de Perus. Estas hipótesis são de difícil aceitação, já que o maciço é muito pequeno, e sua colocação deve ter-se processado em intervalos menos dilatados.

\subsubsection{Os turmalina granitos de Perus}

Os turmalina granitos de Perus se distribuem sob forma de várias bossas de pequenas dimensões, algumas ocorrências menores e uma série de veios e diques de turmalina pegmatitos associados. O nível erosivo no Domínio São Roque foi o sufíciente para exumar maciços de colocação certamente profunda, como o batólito Cantareira, mas não proporciona ainda uma boa exposição para os turmalina granitos, já que as bossas mapeadas representam cúpulas com "roof pendants" preservados (apófises de corpos que sâo maiores em profundidade?). Em algumas pedreiras, o capeamento por uma cobertura metassedimentar é inferido. 


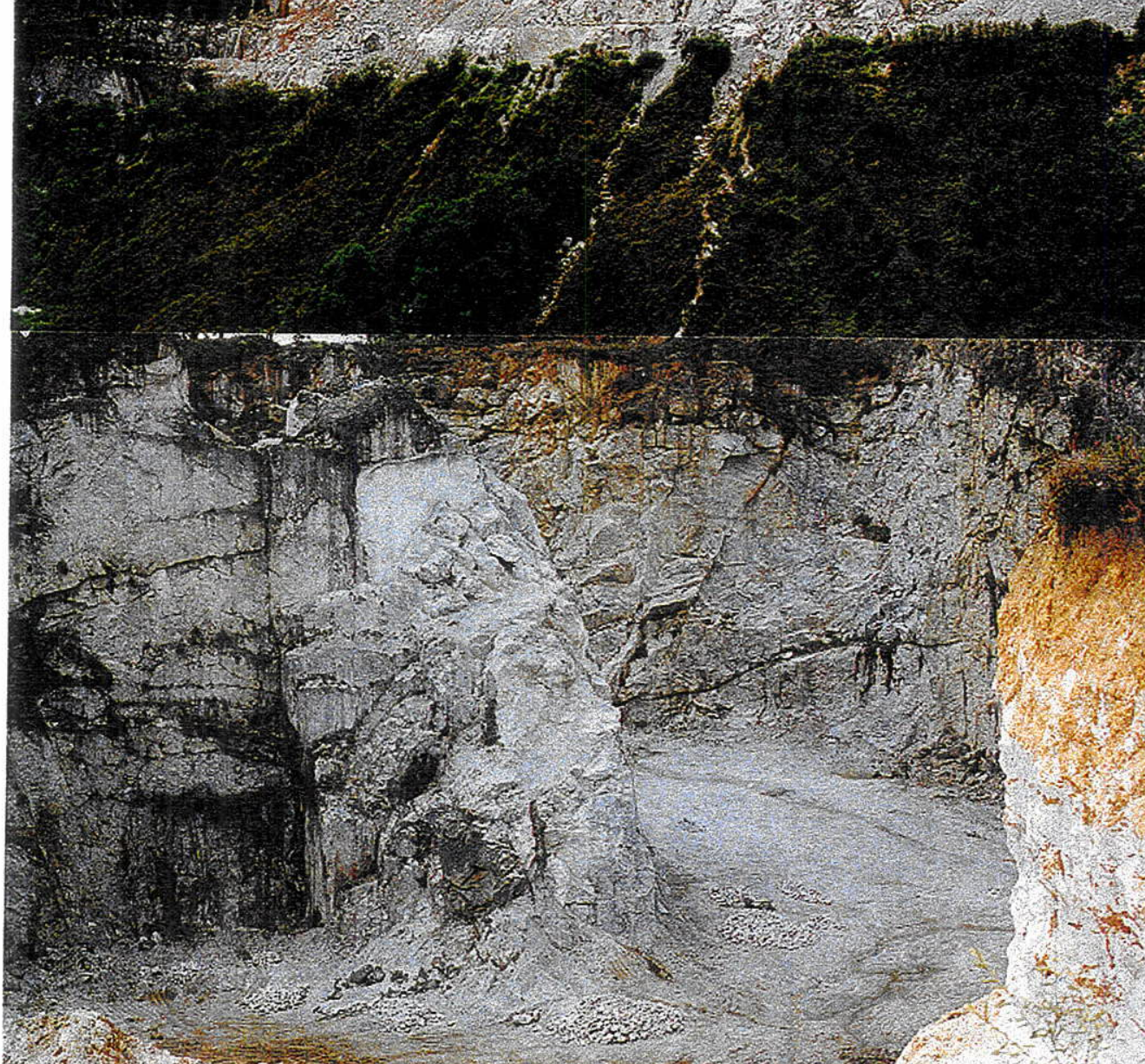

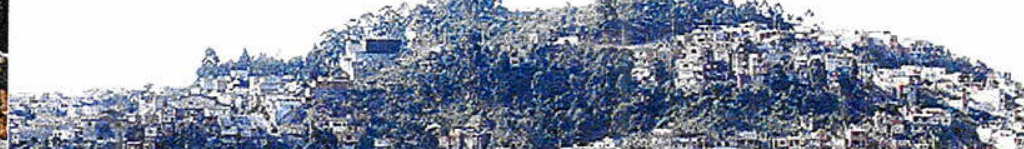

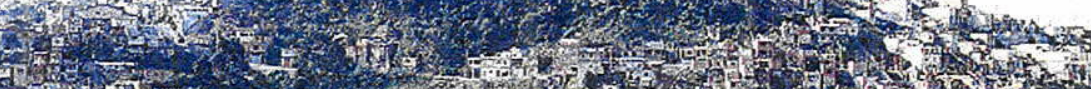

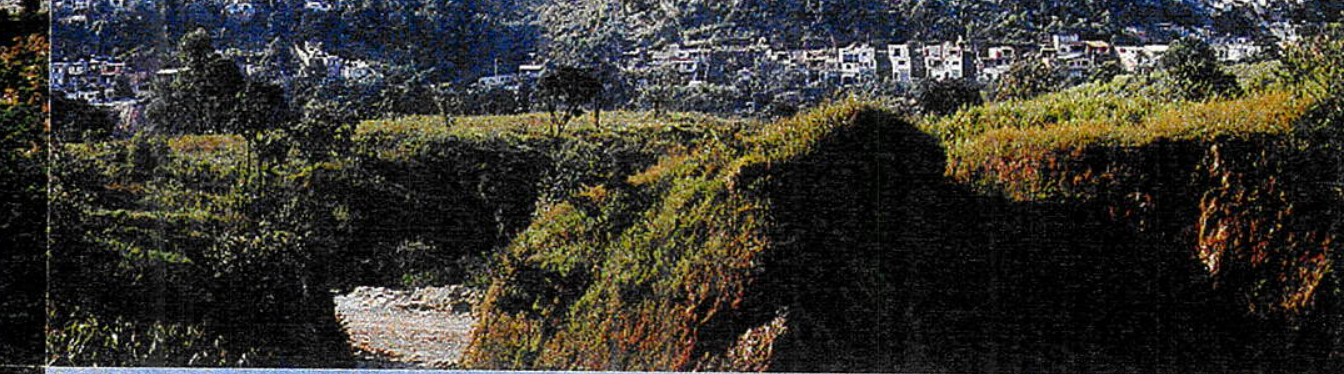

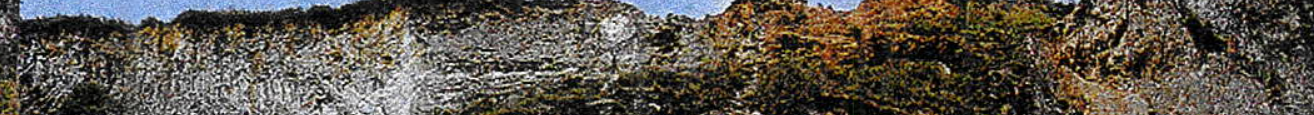
(2) is

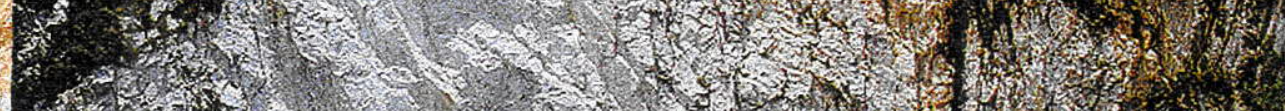

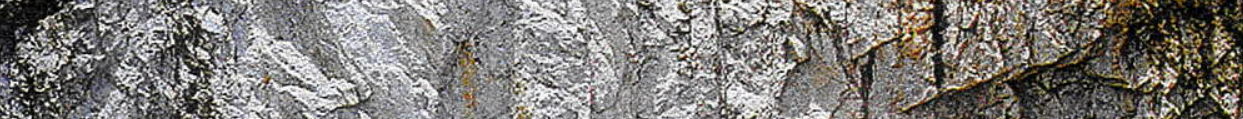

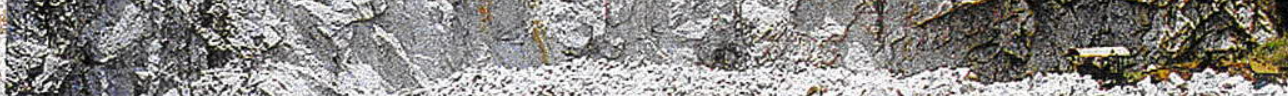

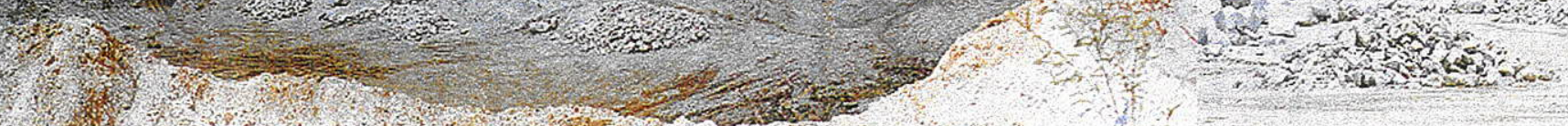

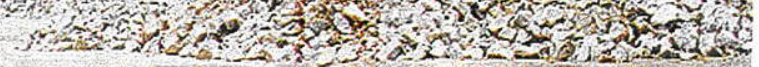




\begin{tabular}{l|l}
4.1 & 4.2 \\
\hline 4.3 & 4.4
\end{tabular}

Foto 4.1. Visão geral, para NW, da frente de lavra da pedreira Panorama (julho de 1996), no maciço Cantareira. É observado o solo bege-amarronzado desenvolvido sobre o granito, e a falta geral de afloramentos, cobertos neste caso pela vegetação (ver localização no Anexo 2).

Foto 4.2. Vista geral do morro do Perus, desde o topo da pedreira 2, Fiore (julho de 1986; ver Anexo 2). O pequeno maciço homônimo aflora apenas como alguns matacões na parte alta do morro; exposições referidas em trabalhos anteriores (e.g., Dantas, 1980; Carneiro, 1983) estão hoje cobertas por urbanizações.

Foto 4.3. A pedreira Dellantônia em julho de 1996 (Anexo 2). Vista geral da exploração, para SE; as paredes no primeiro plano e no fundo são constituídas, em proporções variáveis, por fácies bandada e pegmatóide interna. Em primeiro plano, na parte inferior, ocorre um xenolito alongado, de dimensões métricas, de xistos.

Foto 4.4. A pedreira Botuquara em julho de 1996 (Anexo 2). Vista geral para E; na parede exposta, predomina a fácies pegmatóide interna. A superficie de xistos alterados (cor marrom), à direita, expõe parcialmente a superficie da falha que separa esta pedreira da vizinha Dellantônia. 
O número total de ocorrências deve ser de dezenas, principalmente a de diques e veios pegmatóides, mas a maioria delas apenas é notada como manchas de alteração caolínica em encostas e cortes de estradas vizinhais e, em consequência, não aparecem representadas no mapa do Anexo 2; algumas dessas áreas de alteração foram escavadas para lavra manual em pequena escala do caolim (e.g., à $\mathrm{N}$ da estrada Di Sandro, ver Anexo 2; Figura 4.2). As maiores ocorrências de turmalina granitos e pegmatitos associados, com as melhores exposições por causa da existência de pedreiras, aparecem na porção centro-oeste da área de mapeamento (Anexo 2). São os corpos $1 \mathrm{a}(250 \times 150 \mathrm{~m}$; pedreira Dellantônia, em exploração; Foto 4.3) e 1 b (150 x 100 m; pedreira Botuquara, em exploração; Foto 4.4), e 2 até 5 (pedreiras Construcap em turmalina granito, Fiori, região dos Lagos e local da mina de água Jaraguá, respectivamente; desativadas); dos últimos, o maior é o corpo $2(250 \times 100 \mathrm{~m})$. As formas variam: subcirculares a elipsoidais (corpos $1 \mathrm{~b}$ e 4), retangulares (corpos 2 e 5) e sigmoidais-fusiformes (corpos la e 3 ).

A observação do mapa do Anexo 2 (ver também Figura 4.1) mostra que estas ocorrências teriam o seu "emplacement" controlado pela aparição de 2 sistemas de zonas de cisalhamento, um de direção $\mathrm{NE}$, o outro NW, das quais o NE é o dominante em escala mais regional (ver Anexo 1 e Capitulo 3); praticamente todas as ocorrências destes turmalina granitos, e de suas fácies associadas, estão localizadas nestes dois sistemas (a maioria, de fato, encontra-se inserida no sistema NE). Nota-se também que a intersecção destes dois sistemas define um quadrilátero de uns $850 \times 500 \mathrm{~m}$, em cujo contorno, e nas suas imediações, estão colocados praticamente todos os corpos maiores (bossas) e muitas das manifestaçס̃es menores (Anexo 2; Figura 4.1). No sistema NE, para $N$, são encontradas manifestações correlatas na forma de veios e diques, com orientação NE.SW adaptada à das zonas de cisalhamento, e que parecem extender-se para fora do mapa do Anexo 2, possivelmente até as vizinhanças do maciço Mairiporã (comparar com Anexo 1).

Os contatos entre os turmalina granitos e a rocha encaixante metamórfica são observados em varias situações nas pedreiras; em geral, são claramente discordantes e verticais. Eles estão expostos nos cortes das pedreiras (e.g., na entrada e porções laterais da pedreira la, nos limites externos da pedreira $1 \mathrm{~b}$, etc.); aqui são também observados contatos em degraus, marcados pela presença de dois sistemas de fraturas (reais ou virtuais) presentes nas rochas encaixantes: um deles vertical e discordante, o outro aproveitando a existência dos planos de debilidade da foliação e do acamamento reliquiar (Foto 4.5). No terreno, os contatos com os xistos encaixantes estão geralmente intemperizados e cobertos por vegetação, mas são claramente visíveis em alguns locais onde a cobertura vegetal foi retirada (e.g., em volta da bossa que constitue a pedreira la). As evidências gerais sugerem que o nivel de erosão afetou apenas as partes superiores destas bossas (e.g., a presença de xenólitos de dimensões decamétricas, que seriam verdadeiros roof pendants), mas apenas a pedreira Fiore ainda mostra o topo preservado, capeado por rocha metamórfica.

É comum encontrar xenólitos das rochas metassedimentares no interior das bossas, com dimensões que variam entre métricas ou decamétricas até centimétricas (Foto 4.6). As foliações e/ou acamamentos destes xenólitos apresentam notável paralelismo com aquèle observado nas mesmas rochas fora dos limites das intrusões. Estas pequenas massas de magmas, em consequência, invadem sem provocar rotações nos blocos de rochas encaixantes englobados durante o processo, provavelmente também deixando eles 
na posição original (ou seja, com pouca ou nenhuma movimentação lateral ou vertical). Desta forma, o mecanismo de colocação dos magmas deve processar-se com acomodação lateral e vertical em função: a) de deformações plásticas locais das rochas encaixantes (cunhas de magmas introduzidas em fraturas verticais; "ballooning" limitado) e b) de deslocamentos de pequenos blocos de rochas encaixantes ao longo de fraturas e pequenas falhas locais. A velocidade desta invasão magmática, em volumes pequenos, deve ser bastante rápida. Algumas evidências geológicas confirmam esta possibilidade, até em níveis crustais relativamente rasos. Assim, o tempo necessário para a formação do "domo" intrusivo na parte apical do Monte Santa Helena, em Washington, USA, responsável pela posterior explosão piroclástica em maio de 1980, foi aparentemente de poucos meses ou anos, como comprovado pelo exame do "inchaço" do cone nesse local com metodologia topográfica e geodésica (o "inchaço" atingiu dimensões de 1,5 x $3 \mathrm{Km}$, com velocidades de expansão máxima de até 2,5 metros ao dia no Monte Santa Helena; no Kilauea, Havai, foram registradas expansões de vários $\mathrm{mm}$ ao dia, durante as etapas que precedem as efusões; ver trabalhos apresentados em Lipman \& Mullineaux, 1981; H. Ulbrich, com. pessoal).

Idade. As idades até agora determinadas não parecem combinar com as evidências geológicas e petrográfico-geoquímicas, nestes granitóides. As feições geológicomineralógicas sugerem que se trata de granitóides altamente evoluidos, cristalizados perto da superfície, e em regime provavelmente "pós-tectônico", diferentes portanto das evidências apresentadas pelo vizinho batólito Cantareira (cristalizado em maior profundidade, de natureza menos evoluida, etc.). Cordani \& Bittencourt (1967) determinaram idades $\mathrm{K} / \mathrm{Ar}$ (em micas de Li) de $650 \pm 20$ e $640 \pm 20 \mathrm{Ma}$ nos turmalina granitos, enquanto que Teuppenhayn (1994) identifica neles uma idade U/Pb (em monazita) de $566 \pm 6 \mathrm{Ma}$. Estes dados, evidentemente, são contraditórios. O magmatismo Cantareira, a julgar pelo primeiro conjunto de idades, poderia estar associado à geração dos turmalina granitóides de Perus, mas a idade $\mathrm{U} / \mathrm{Pb}$ afastaria estes últimos do primeiro evento. A questão não está resolvida.

\section{As fácies dos turmalina granitos}

Os turmalina granitos de Perus são compostos por três fácies: a bandada, a maciça e a pegmatóide. A fácies bandada predomina amplamente nas bossas. A fácies maciça é homogênea e de ocorrência muito restrita, insinuando em alguns casos apenas um início de bandamento; aparece dispersa pelas intrusões, ou próxima às grandes inclusões de rochas metassedimentares encontradas nas intrusões. A fáçies pegmatóide é dividida, pela sua localização, em duas: a pegmatóide interna, encontrada como veios e bolsões nas bossas de turmalina granitos, e a externa, constituindo um conjunto disseminado de corpos pegmatíticos menores diretamente encaixados em rochas metamórficas.

As observações geológicas nestas pedreiras, como resumido nas observações descritas a seguir, indica que os turmalina granitos cristalizaram em pequenas câmeras magmáticas por resfriamento de magmas muito diferenciados, com formação inicial da fácies bandada e crescente concentração de alguns elementos ( $\mathrm{Li}, \mathrm{F}, \mathrm{B}, \mathrm{U}$, etc.) nos magmas hiperfluidos restantes, cuja posterior mobilização nas mesmas câmeras gera a cristalização da fácies pegmatóide interna, em função de um processo essencialmente contínuo. 
Dados mais detalhados sobre a petrografia e a estrutura destas fácies podem ser encontrados no Capítulo 5.

Fácies bandada. Esta fácies constitui cerca de 60 a $80 \%$ do volume de rocha aflorante nas bossas, marcada pela alternância de bandas com níveis claros e escuros, principalmente por variaçōes mineralógicas. Cada uma das bandas, com espessuras da ordem de 1 a $5-10 \mathrm{~cm}$, mostra passagem gradacional, mas rápida, de níveis quartzofeldspáticos (tipicamente, $2 / 3$ a 4/5 da banda total) até outros com presença de turmalina. As cores são claras, moteadas de preto nos níveis com turmalina; são, em conjunto, leucocráticas a hololeucocráticas (índice de cor de 1 até 10 ).

Texturalmente, estas rochas são equigranulares médias a grosseiras, em parte com indicação de mudanças sistemáticas no tamanho dos grãos. A mineralogia mostra feldspato potássico e plagioclásio esbranquiçados (separáveis entre si apenas quando são observadas as geminações características), quartzo, turmalina e alguma granada, quase sempre presente. Os feldspatos são em geral subidiomórficos a tabulares, o quartzo equidimensional a irregular, e turmalina e granada sempre idiomórficas.

Estas bandas repetem-se ritmicamente, constituindo conjuntos de várias unidades, ou até várias dezenas de unidades, com percurso constante por vezes por alguns dm, mas tipicamente por alguns metros. Em geral, apresentam deformaçð̃es que formam sistemas de dobras bastante complexos, do tipo "dobras de interferência".

As bandas são frequentemente cortadas por veios e "diques" pegmatóides, posicionados ora de maneira concordante a subconcordante, ora cortando perpendicular ou obliquamente $o$ bandamento ígneo. Os contatos entre as bandas e este material pegmatóide são bruscos, em geral (para maiores detalhes, ver fácies pegmatóide interna)..

Fácies homogênea. Esta fácies é de distribuição muito restrita, aparecendo apenas em alguns pontos nas pedreiras visitadas (e.g., ponto 74, pedreira 1a, Anexos 2 e 3). Caracteriza-se a rocha por mostrar estrutura maciça de granulometria media a fina, com índice de cor variando de 1 a 3 , constituída por feldspatos, quartzo, turmalina e alguma granada.

Fácies pegmatóide interna. Esta fácies é a segunda em abundância. Apresenta-se como bolsões, geralmente de volume considerável, com dimensões métricas a decamétricas, ou como veios ou corpos irregulares-tabulares, discordantes a subconcordantes, de percurso e espessuras variáveis ("sills" e "diques"). A sua distribuição é irregular. Veios e "diques" estão presentes, em proporçð̃es variáveis, em todas as bossas, enquanto que os bolsões ocupam partes significativas de algumas pedreiras. Nas pedreiras $1 \mathrm{a}$ e $1 \mathrm{~b}$, em particular, destacam-se estes bolsões pegmatóides internos, formando entre 20 e $40 \%$ do volume observado de rocha granítica, mapeados como unidades independentes; em algumas paredes destas pedreiras, predominam amplamente as fácies pegmatóides (ver Anexo 2, Figura 4.1; ver também Foto 4.4).

Composicionalmente, os veios e diques de menores dimensões são turmalina pegmatitos leucograníticos de granulação grosseira a muito grosseira (dimensões até 3-4 $\mathrm{cm}$ ), com feldspato potássico, quartzo e turmalina, por vezes com granada e apatita como 
minerais acessórios. O plagioclásio parece subordinado ou ausente; o feldspato é tabular subidiomórfico, e apenas turmalina e granada, quando presente, são idiomórficas. Os veios, com espessuras similares às das bandas, formam sistemas interconetados entre si, com contatos bastante bruscos; aparecem em parte em disposição subconcordante ao bandamento da fácies bandada (portanto, com percurso retilíneo ou dobrado, conforme o comportamento das bandas), mas são também discordantes, cortando as bandas em ángulos variados. Os diques, discordantes e com contatos bruscos, são ora verticais, ora aparecem mais ou menos inclinados, mas claramente cortam as bandas e são portanto posteriores. Podem prolongar-se por vários $\mathrm{m}$ e mostrar espessuras decimétricas a métricas; a granulação é grosseira a muito grosseira, inequigranular, com bordas marcadas por vezes por prismas de turmalina, perpendicularmente orientados ao contato com a fácies bandada. Aparentemente, aumentam as proporções de veios e "diques" de pegmatóides no topo das cúpulas.

Os bolsões maiores mostram feições mineralógicas similares, mas os grãos de quartzo e principalmente os de feldspato potássico apresentam comumente dimensões decimétricas $(10-15 \mathrm{~cm})$, bastante frequentemente com estrutura gráfica predominante. A mineralogia é também mais variada, com abundância de minerais acessórios, em geral distribuídos de maneira irregular (apatita, concentrações tardias de muscovita e micas de $\mathrm{Li}$ ); entre as turmalinas, quase sempre prismáticas e por vezes com mais de $10 \mathrm{~cm}$, predominam as de cor preta (schorlita), mas são abundantes as róseas e, em parte, as esverdeadas, por vezes formando cristais zonados. Turmalinas róseas e verdes são inexistentes em outras fácies dos turmalina granitos. É também muito grande a variedade de minerais secundários, localizados em pequenos bolsões e em fraturas (argilominerais, opala, minerais de U, etc.; e.g. Atencio, 1991, para mais detalhes ver Atencio, 1988 e Atencio \& Hypólito, 1994). A distribuição dos minerais é também bastante irregular, visível principalmente pela concentração das turmalinas, formando manchas irregulares ou faixas de contornos e percursos geralmente irregulares, dentro da massa feldspáticoquartzosa predominante.

Fácies pegmatóide externa. Nas vizinhanças dos turmalina granitos, e com mineralogia similar, são encontrados inúmeros veios e diques de pegmatóides, cuja colocação é controlada aparentemente pela presença das faixas de cisalhamento NE e NW (Anexo 2). Estas características geológico-mineralógicas sugerem uma íntima relação genética entre estas fácies pegmatóides externas e os turmalina granitos. Os corpos pegmatíticos, com dimensões entre $25 \times 15 \mathrm{~m}$ até $150 \times 50 \mathrm{~m}$, estão encaixados ora paralelamente às foliações dos xistos regionais, ora de maneira discordante preenchendo fraturas nos metassedimentos. As relações entre estes corpos e as rochas encaixantes ficam expostas em algumas lavras manuais, realizadas para exploração local de caolim (Fotos 4.7 e 4.8 ).

Estes pegmatitos são homogêneos e não zonados, apresentando mineralogia constituída por quartzo, feldspatos, turmalina, granada, muscovita e apatita; a textura é inequigranular a equigranular, com turmalina como principal mineral idiomórfico, com tamanhos de grãos variando entre 2 e $10 \mathrm{~cm}$. 

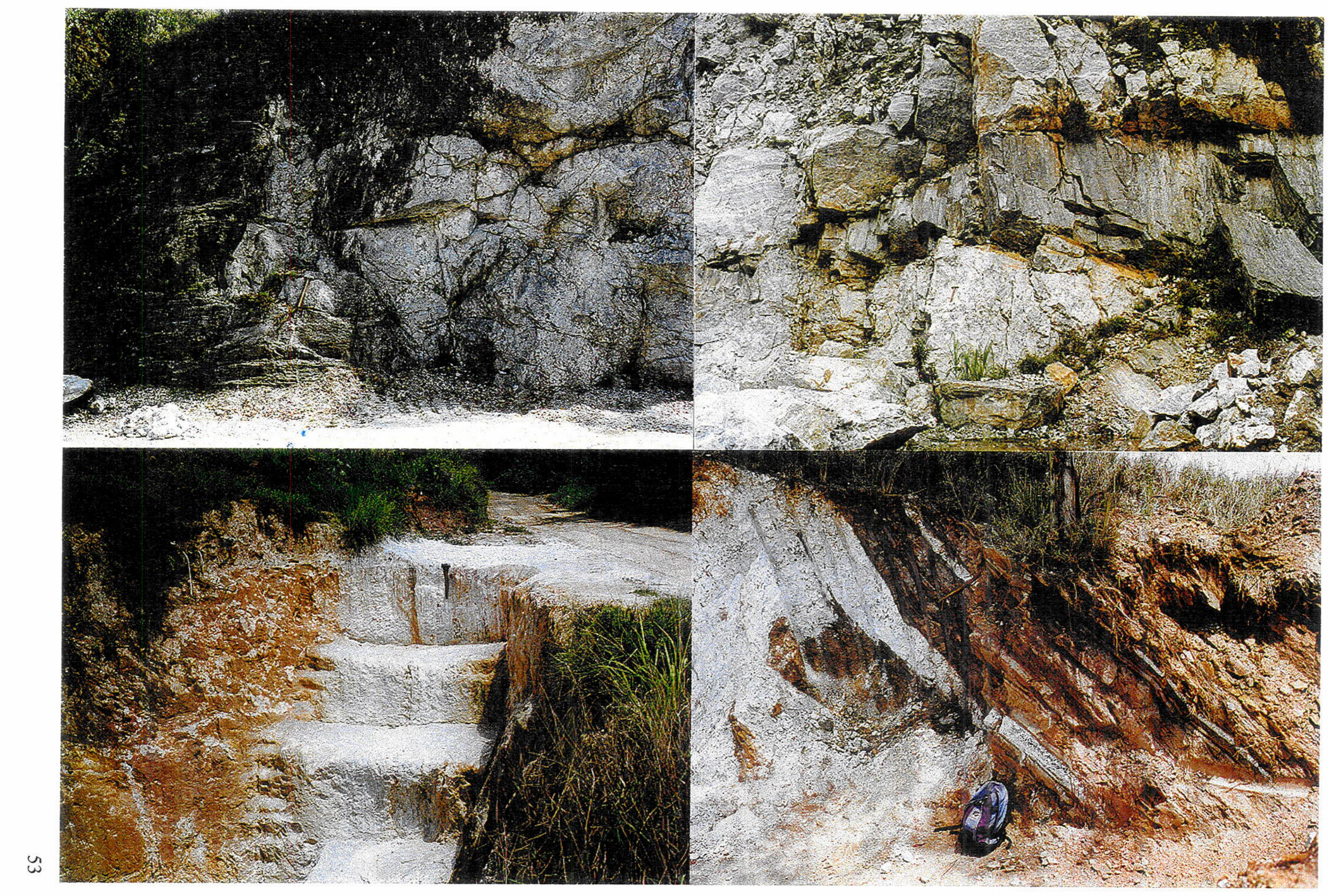


\begin{tabular}{l|l}
4.5 & 4.6 \\
\hline 4.7 & 4.8
\end{tabular}

Foto 4.5. Contato escalonado entre o turmalina granito da pedreira Dellantônia (à direita) e a rocha metamórfica encaixante (à esquerda), constituídos em boa parte por níveis cálcio-silicáticos. Os contatos horizontais estão controlados pelo acamamento reliquiar da rocha encaixante. Observar também os finos veios intrusivos (espessuras de $\mathrm{mm}$ a $\mathrm{cm}$ ), tanto horizontais como verticais, do turmalina granito na rocha metamórfica.

Foto 4.6. Xenólito de xistos encaixantes, de dimensões métricas, em turmalina granitos (pedreira Fiori, ver Anexo 2). A foliação do xenólito mostra disposição similar à que predomina na rocha encaixante, nos contatos.

Foto 4.7. Corpo tabular concordante de turmalina granito, lavrado para obtenção de caolim. A foliação dos xistos e os contatos com este corpo são subparalelos (ponto 105, Anexo 3).

Foto 4.8. Corpo irregular concordante de pegmatito, localizado em xistos; observar os veios e diques pequenos concordantes de pegmatitos, aparentemente desvinculados de corpos maiores. Lavra para obtenção de caolim (ponto 52, Anexo 3). 


\subsection{ASPECTOS ESTRUTURAIS}

As unidades mapeadas nesta região apresentam, sem exceção, os reflexos de uma forte atividade tectónica pós-emplacement e pós-metamorfismo, marcada por presença de falhas e, principalmente, de sistemas de zonas de cisalhamento NE, NW e E-W. Entre estes, predomina o sistema NE (NE 30-50 ) sobre o NW (NW40-60 ); a terceira direção é menos importante. $\mathrm{O}$ desenvolvimento de estruturas, em resposta aos esforços, se faz de maneira diferenciada de acordo com a litologia. Nos xistos, a deformação provoca uma inflexão para NE-SW na direção geral de foliação, além do desenvolvimento de planos de fratura e lineações minerais localizadas; nos granitos, ela condiciona a aparição de sistemas de juntas, junto com estreitas faixas de cisalhamento paralelas e algumas falhas. As estruturas citadas, em xistos e granitos, estão representadas nos diagramas da Figura 4.2 .

Os xistos de maneira geral apresentam boa foliação, orientada segundo a direção regional ENE-SWS, marcada pela disposição planar de minerais micáceos e de sillimanita no plano de xistosidade, com mergulhos moderados $\left(40^{\circ}\right)$ para $\mathrm{NW}$ (ver representação de foliações dos xistos na Figura 4.2). Próximo às região de maior cisalhamento, os xistos sofrem uma deflexão de uns $10-20^{\circ}$ para NE-SW, com correlato aumento no valor do mergulho, chegando-se localmente à verticalização e paralelismo com as zonas de cisalhamento, principalmente no sistema NE-SW. Localmente, formam-se nos xistos estruturas antiformais e sinformais com plano axial subvertical orientado segundo direção W-E, provavelmente relacionadas com a deformação regional (Figura 4.2).

A localização predominante das ocorrências de turmalina granitos (bossas dos granitóides, veios e diques pegmatóides) ocorre dentro, e nas vizinhanças, da interseção entre os dois sistemas $\mathrm{NE}$ e NW, como claramente visível nos mapas e discutido previamente; em parte, também a direção dos diques é visivelmente controlada pelo sistema NE (ver acima, item 4.2.4; Anexo 2, Figura 4.1).

Nos turmalina granitos as manifestações rúpteis e as faixas de cisalhamento aparecem segundo duas direções, $\mathrm{N} 30^{\circ}-40^{\circ} \mathrm{E}$ e $\mathrm{N} 50^{\circ}-60^{\circ} \mathrm{W}$ (Figura 4.2). Os sistemas de juntas e algumas falhas se fazem mais intensos e melhor marcados nos bolsões dos pegmatóides internos encontrados nas bossas, e menos na sequência bandada. As interseções destas duas direções parecem formar regiões de distensão dentro das bossas, e nelas se posicionariam de preferência os bolsões pegmatíticos.

Como acontece em escala regional, o sistema NE de deformação é bem mais desenvolvido nesta escala local. A observação ao microscópio petrográfico, em amostras orientadas de turmalina granitos, mostra que na fácies bandada do turmalina granito a deformação atinge principalmente os níveis mais enriquecidos em quartzo, com desenvolvimento preferencial de faixas miloniticas caracterizadas por intensa recristalização do mineral em subgrãos envolvendo alguns relitos de feldspato; nos níveis enriquecidos em feldspato a deformação é evidenciada pela tênue marcação da geminação em plagioclásios (lei da albita), fraturamento dos grãos e recristalização do quartzo intersticial. Ao que parece, nestes níveis os grãos de feldspatos conseguiram absorver bem o stress aplicado, impedindo a intensa recristalização encontrada nos níveis ricos em quartzo. 


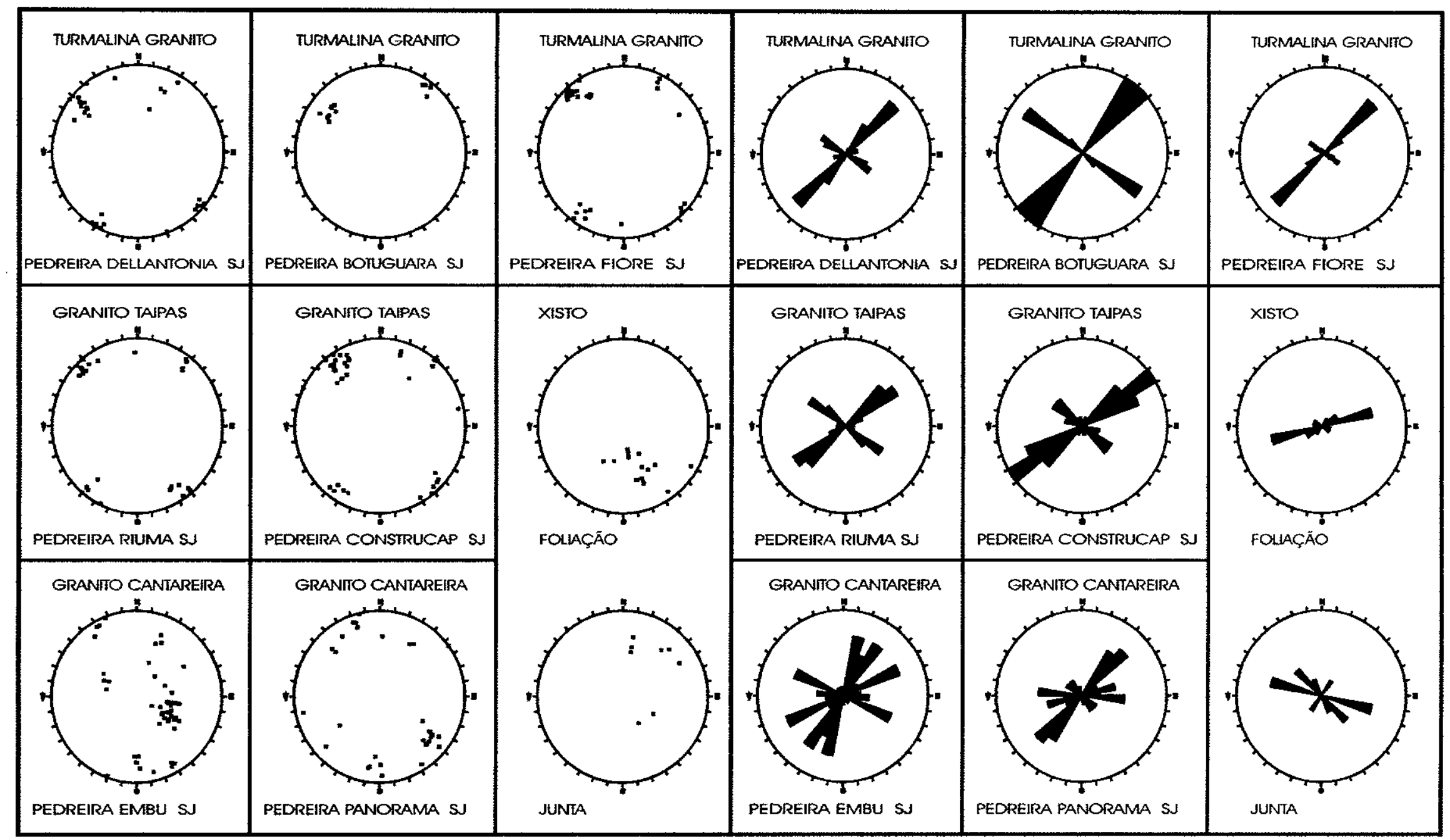

Figura 4.2. Diagramas de polo e roseta mostrando as direçōes das principais planos de fraturamento medidos nos granitos. Păra o xisto tem-se tambem a representação das direçōes dos planos de fraturamento. 
No granitóide Taipas, aparece um padrão de deformação muito próximo com o que é observado nos turmalina granitos, com a manifestação proeminente das duas direções principais $\mathrm{N} 30^{\circ}-40^{\circ} \mathrm{E}$ e $\mathrm{N} 50^{\circ}-60^{\circ} \mathrm{W}$ (Figura 4.2). No granitóide Cantareira, são encontradas as duas direções predominantes NE e NW, mas aqui também é verificada a presença da direção $\mathrm{E}-\mathrm{W}$, principalmente na pedreira Panorama; nesta última, é notado um maior desenvolvimento de planos de falha, orientados segundo a direção principal $\mathrm{NE}$, muitas vezes evidenciado por lineações em espelhos de falhas verticais marcadas por estrias minerais (Figura 4.2.).

Não existem evidências para resolver a questão sobre a sequência entre a deformação dúctil e a rúptil, mas é provável que a segunda seja posterior, em função de um processo contínuo de exumação e resfriamento regional e a consequente passagem de um regime dúctil para outro rúptil; é provável que a deformação tenha se alastrado até épocas muito posteriores às da colocação dos granitóides.

\subsubsection{Deformação sin-magmática nas fácies bandadas dos turmalina granitos}

A deformação no conjunto das fácies bandada se faz presente em todas as bossas de turmalina granitos, com maior ou menor intensidade em função da proximidade em relação aos bolsões dos pegmatóides internos e de seu volume. Deve ser enfatizado especialmente que as dobras não deformam plasticamente os minerais da fácies bandada, tratando-se portanto de um fenômeno inteiramente sin-magmático, que acontece após a formação das bandas em câmera magmáticas fechada, mas antes da completa cristalização das bandas (Foto 4.9; ver também Hasui, 1963).

Os bolsões pegmatóides de maior volume podem ou não atingir o topo das cúpulas, dependendo muito da sua dimensão e forma. São frequentemente observados rompimento e compressão lateral nos conjuntos de bandas, que exibem dobramentos aparentemente caóticos na imediações das regiões com pegmatitos, evoluindo para um padrão de dobramentos simétricos ao aumentar a distância dos bolsões.

Nas adjacências dos bolsões pegmatóides de menor volume são também observados sinais de perturbação na sequência bandada, marcados pela verticalização do bandamento acompanhada de estiramento longitudinal e estreitamento transversal das bandas individuais, que acompanham irregularmente os contornos destes bolsões (e.g., Foto $4.9 \mathrm{~d})$.

$O$ aspecto geral das dobras da sequência bandada mostra um padrão de interferência muito parecido com o tipo intermediário entre os padrões "caixa de ovos" e "em laços" de Ramsay (1987), constituído por duas direções de dobramentos D1 e D2, (Figura 4.3). É lembrado que estas direções de dobramento devem ser consideradas "virtuais", já que a deformação afeta neste caso um magma granítico que está cristalizando, e não uma rocha sólida sob condicões de deformação plástica; assim, é perfeitamente possível que os dois sistemas D1 e D2 sejam contemporâneos, ou estejam intimamente relacionados entre si, e não sejam necessariamente sequênciados e com idades muito diferentes. A identificação dos dois sistemas foi possível através da observação de alguns grandes blocos desprendidos do maciço por detonação, na pedreira Fiore. 
A série de Fotos 4.9. mostra os dois sistemas D1 e D2 com seus respectivos eixos de dobramento orientados nas direções aproximadas $\mathrm{E}-\mathrm{W}$ e $\mathrm{N} 10^{\circ} \mathrm{W}$; estas direções estão deslocadas em torno de $30^{\circ}$ dos dois planos predominantes de juntas (Figura 4.2). As medidas indicadas são aproximadas, porque inexistem nas pedreiras as seçðes estruturais paralelas ao plano horizontal.

As dobras D1 (Foto 4.9a) de maneira geral não estão bem expostas, caracterizamse por serem do tipo inversa, com plano axial mergulhando de $52^{\circ}$ a $55^{\circ}$, simétricas, e com ápice da mesma espessura que os flancos (tipo isópaca), ver Hasui \& Mioto (1992).

As dobras D2 (Fotos $4.9 \mathrm{~b}$ e $4.9 \mathrm{c}$ ) apresentam plano axial predominantemente vertical, por vezes mergulhando com ângulo moderado, são simétricas, cont ápice mostrando leve espessamento (tipo de achatamento) e exibem ainda dobras parasíticas nos flancos. O comprimento de onda $\lambda / 2$ é da ordem de $2,7 \mathrm{~m}$, e a amplitude é variável, em torno de $1,2 \mathrm{~m}$.
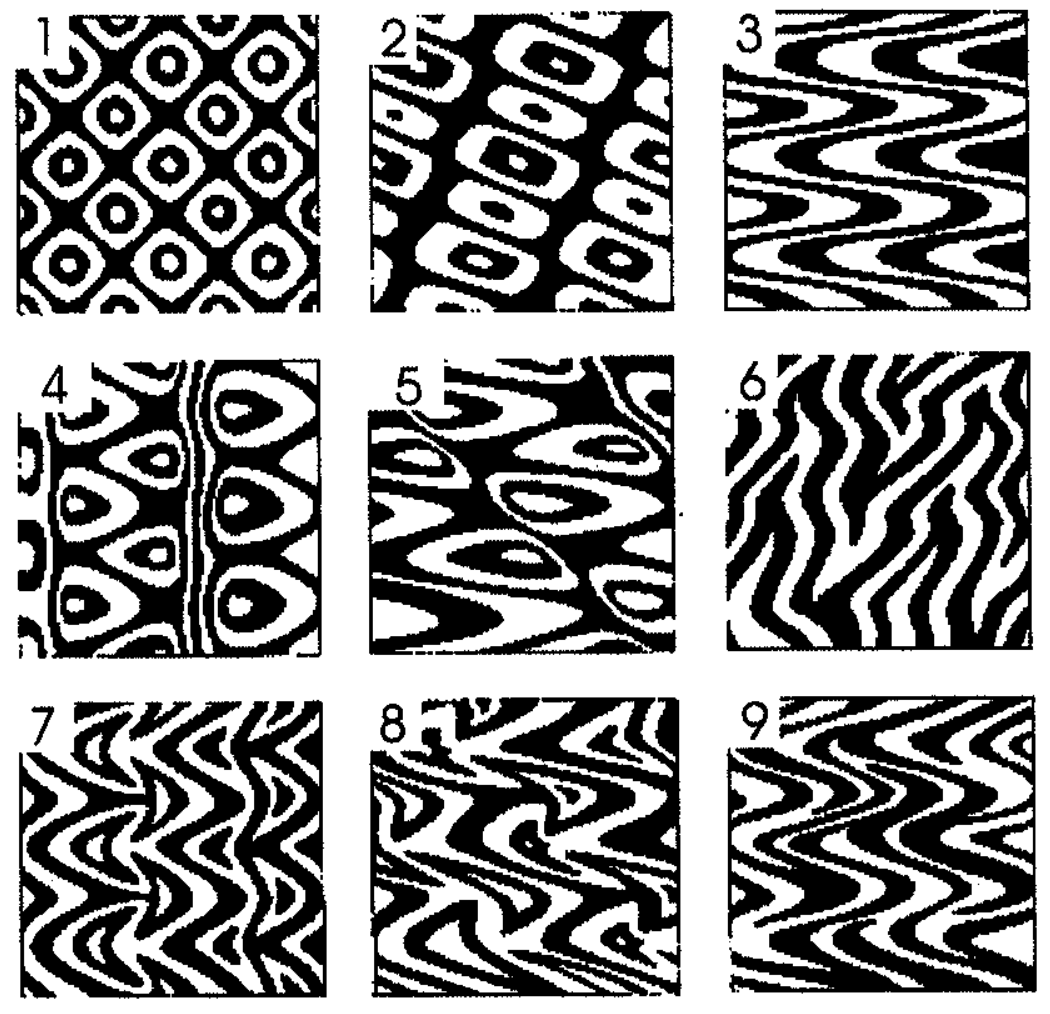

Figura 4.3. Esquema proposto por Ramsay \& Huber (1987), mostrando os diversos padrões de interferência para duas direções de dobramento perpendiculares. Os tipos mais comuns são "caixa de ovos" (1), "em laço" (2) e os intermediarios (3, 5 e 6). Estes últimos são gerados por variações no valor do mergulho do eixo de redobramento. 


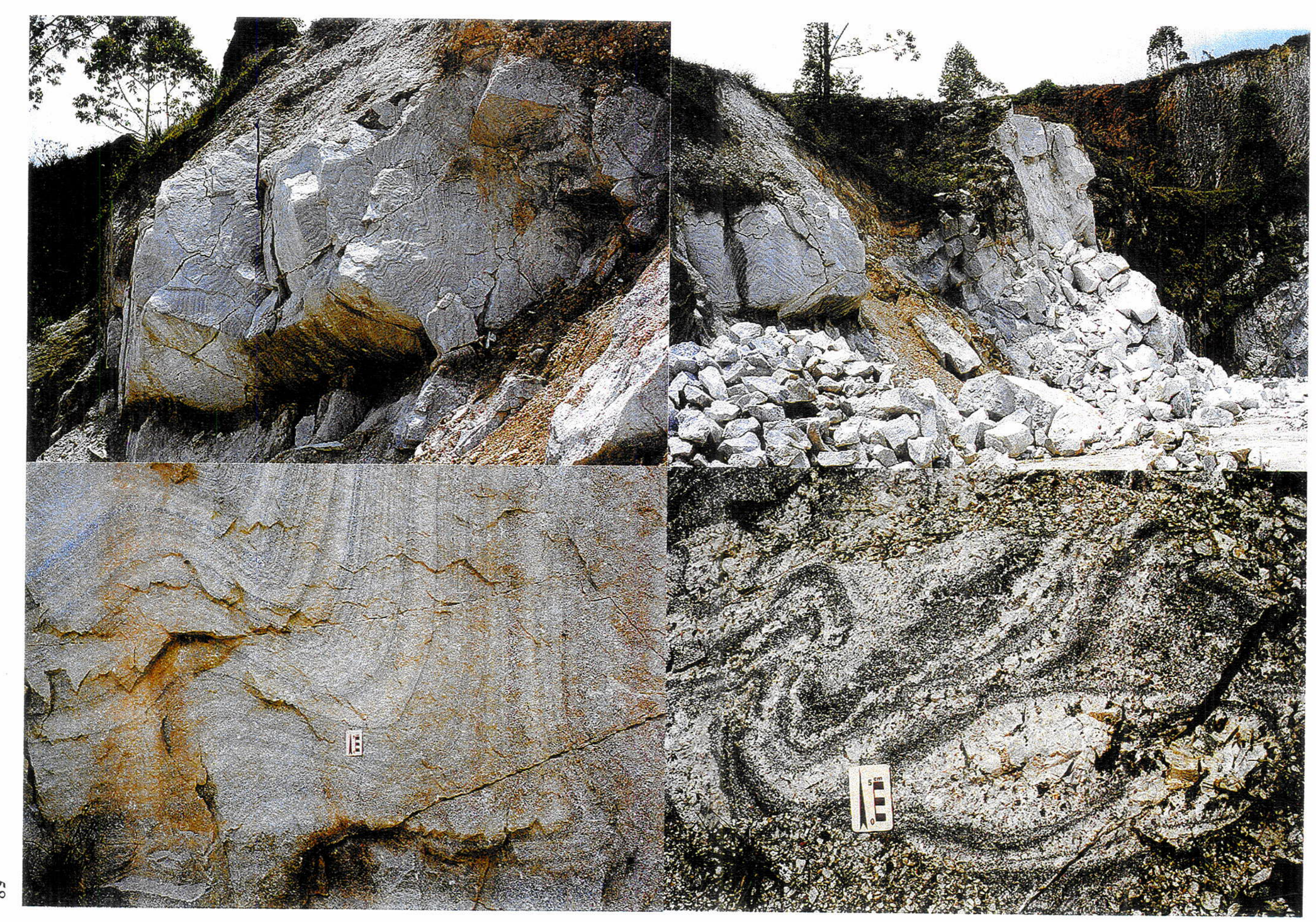




\begin{tabular}{l|l}
$4.9 a$ & $4.9 b$ \\
\hline $4.9 c$ & $4.9 d$
\end{tabular}

Foto 4.9. Ilustrações do padrão de dobramentos nos turmalina granitos. a) padrão Dl, com eixo de dobramento lesteoeste (pedreira Botuquara); b) padrão redobrado em D2, eixo com orientação norte-noroeste (pedreira Botuquara); c) padrão D2 (pedreira Fiori); d) padrão irregular a cático, com participação de veios pegmatóides, em parte acumulados formando lentes de tamanhos maiores; (pedreira Dellantônia). 


\title{
CAPÍtULO 5
}

\author{
PETROGRAFIA
}

Neste capítulo são apresentadas as principais características petrográficas dos litotipos encontrados na área de mapeamento, com ênfase principal nos granitóides. Inicia-se a descrição petrográfica com uma breve referência às rochas metamórficas (xistos. xenólitos, anfibolitos). A seguir, são descritos os vários tipos de granitos. Tabelas com dados modais e diagramas Q-A-P-M acompanham as descrições.

\subsection{ROCHAS ENCAIXANTES}

Algumas observações realizadas em amostras de xistos, xenólitos e anfibolitos, do conjunto de rochas encaixantes, são fornecidas a seguir (para descrições mais detalhadas da petrografia de rochas metamórficas desta região, ver em particular Cordani et al., 1963; para descrições de rochas afins, em áreas vizinhas, ver Carneiro, 1983; Dantas, 1990; Juliani, 1993). A seguir são descritos os vários tipos de granitos.

Xistos. Foram selecionadas algumas amostras de xistos (pontos 119, amostras $\mathrm{Pe}$ 13.5; ver localização no Anexo 3). Macroscopicamente, apresentam estruturas fortemente foliadas, com manchas esbranquiçadas e pequenos porfiroblastos de biotita e granada, com cores predominantes cinza esverdeada quando mais frescas, e avermelhadasamareladas quando alteradas (Foto 5.1). A maioria destes xistos representam rochas pelíticas e, em parte, psamíticas recristalizadas. Ao microscópio, a associação predominante observada é quartzo-biotita-sillimanita-granada, ocorrendo ainda plagioclásio, turmalina, minerais opacos, apatita e escassa muscovita. As lâminas apresentam texturas lepido- a granoblástica, em alguns casos com porfiroblastos de granada e biotita, em parte com inclusões múltiplas. Biotita e a pouca muscovita são laminares e responsáveis pela orientação textural, enquanto que sillimanita (geralmente, a variedade fibrolita) aparece como agregados concentrados de fibras com disposição subparalela a radiada.

Os porfiroblastos são de biotita laminar a irregular e de granada equidimensional, ambos com inclusões de quartzo e magnetita. $O$ primeiro mineral mostra pleocroismo variando de castanho escuro a castanho avemelhado; também ocorre como grãos de menor tamanho. Os outros mineras da rocha, em particular o quartzo, constituem agregados granoblásticos de granulação fina. Os minerais opacos aparecem disseminados, inclusos na maioria dos outros minerais; a turmalina aparece como pequenos prismas pleocróicos inclusos nos minerais félsicos.

Xenólitos de rochas calcio-silicáticas. Xenólitos de diversos tamanhos, entre os quais alguns com dimensões mapeáveis, são observados em todas as pedreiras de 
turmalina granitos. Os de maior destaque aparecem na Pedreira la (Anexos 2 e 3). São de xistos e rochas cálcio-silicáticas, com dimensões máximas métricas ou até decamétricas (e.g., tabiques que se estendem por parte considerável da parede de exploração da pedreira). Macroscopicamente, as rochas cálcio-silicáticas mostram marcado bandado composicional reliquiar, alternando-se as bandas cinza claro ou bege ou esbranquiçado com outras mais esverdeadas e escuras (Foto 5.2); a mineralogia geralmente não é reconhecida a olho nú. Ao microscópio, observa-se marcada variação nestas rochas, ocorrendo nelas associações, em proporções variadas, de piroxênios (diopsídio), anfibólios incolores, biotitas pouco pleocróicas (provavelmente flogopitas), quartzo, carbonato, opacos e titanita; aparecem também microclínio, plagioclásio e minerais acessórios. As texturas são desde granoblásticas até nematoblásticas. $O$ bandamento composicional reliquiar é identificado em lâmina pelas concentrações diferentes destes minerais, as bandas e lentes mais escuras tipicamente com maiores teores de piroxênio e flogopita, as mais claras enriquecidas em calcita e/ou quartzo e/ou tremolita. Comumente, o anfibólio aparece alongado a prismático-fibroso, o piroxênio como grãos prismáticos a equidimensionais e subdiomórficos, e as flogopitas como pequenas lâminas inclusas em anfibólios ou piroxênios, mostrando pleocroismo de amarelo a marrom claro. Microclínio e plagioclásio, quando presentes, formam com quartzo agregados granoblásticos de menor tamanho que os outros silicatos mencionados. A calcita (e/ou dolomita) também é encontrada como mosaicos granoblásticos, com contornos irregulares e dimensões variadas. Os grãos de opacos estão distribuídos nos outros minerais, como inclusões.

Anfibolitos. O aspecto macroscópico da rocha é o de um típico anfibolito foliado, de cor preto-esverdeada, com predomínio visível de anfibólio escuro sobre os minerais félsicos, não identificáveis a olho nú. A granulação é variável, fina a grossa, com os cristais de anfibolio se destacando dos grãos restantes.

A mineralogia, ao microscópio, é constituída por hornblenda e plagioclásio, ocorrendo secundariamente quartzo, biotita, titanita, opacos, microclínio, turmalina, epidoto e apatita. A hornblenda, prismática e subédrica é a fase de maiores dimensões, mostra zonalidade fraca e pleocroismo variando de verde amarelo a verde escuro. $\mathrm{O}$ plagioclásio é equidimensional e de granulação fina; apresenta-se comumente geminado (lei de albita, em parte também periclínio). O quartzo aparece como grãos equidimensionais e irregulares, também de granulação fina; neles inclusos, são observados minúsculos prismas de turmalina. As pequenas placas subédricas de biotita mostram pleocroismo variando de castanho avermalhado a verde amarelado, enquanto que a titanita aparece como agregados de grãos xenomórficos, com inclusões de magnetita e ilmenita

\subsection{OS TURMALINA GRANITOS DE PERUS}

As feições petrográficas de maior complexidade são encontradas nos turmalina granitos, principalmente nas fácies bandadas. Nestas, deve ser cuidadosamente observada, em afloramento e na amostra de mão, a disposição dos níveis internos, para definir por um lado a unidade que se repete ciclicamente ("banda" ou "camada", o equivalente do termo inglês layer) e, por outro lado, para identificar as possíveis variações tanto na estrutura interna destas bandas como nos padrões de sua repetição. São abordadas ainda às 
outras fácies do turmalina granitos, a homogênea e as pegmatóides, e as suas relações com a fácies bandada.

As descrições seguintes priorizam os aspectos mesoscópicos, com ilustrações apropriadas por meio de fotografias, sem os quais seria impossivel uma avaliação correta das informações obtidas ao microscópio. As principais feições geológico-petrográficas já foram descritas no item 4.2.4.

\subsubsection{Fácies bandada}

\section{Aspectos mesoscópicos}

Bandamento. $\mathrm{O}$ bandamento nesta fácies bandada aparece claramente definido, visível principalmente pela concentração da turmalina em determinados níveis. As espessuras das bandas (ou camadas) são variáveis, mas tipicamente oscilam entre poucos $\mathrm{mm}$ a alguns $\mathrm{cm}(3-7 \mathrm{~cm})$. Nos melhores exemplos, encontrados em praticamente todas as pedreiras (ver Anexo 2), o bandamento é extremamente regular, com pouca ou nenhuma variação na espessura em percursos de vários decímetros ou até metros. Estas feições estão registradas nas Fotos 5.3 e 5.4.

Dois critérios gerais podem ser utilizados para definir a banda ou unidade de repetição: a) passagens gradacionais entre as proporções de minerais (gradações modais) e nos tamanhos de grãos (gradações texturais) devem ocorrer no interior de uma banda; b) as bandas devem mostrar limites bruscos, definidos seja pela variação brusca no conteúdo de um mineral (limite modal), seja pela passagem brusca em termos de tamanho de grão (limite textural).

Em muitos casos, a utilização destes critérios identifica rapidamente as bandas. Assim, as Fotos 5.3 e 5.4 mostram o padrão de bandas mais repetido nestes turmalina granitos, visivel principalmente pelo incremento gradativo mas rápido no teor das turmalinas. $\mathrm{Na}$ base, ocorre o nivel basal, com quartzo, ambos feldspatos e pouca turmalina, geralmente com tamanhos de grãos menores (poucos $\mathrm{mm}$ ). O nível intermediário da banda aparece com alguma turmalina, mas é constituido principalmente pelos minerais félsicos, com dimensões algo maiores. O nivel superior, finalmente, define-se claramente pelo aumento no teor das turmalinas, com incremento também no tamanho dos grãos (Figura 5.1). Este nível superior aparece também marcado, com bastante frequência, como uma superfície de debilidade que facilita a quebra da rocha naquele local (ver, por ex., a superfície de quebra no nível com turmalina, encontrado no centro da Foto 5.4).

Tipos de bandamento. O padrão descrito é chamado de bandamento normal granocrescente (ver representação esquemática na Figura 5.1). Variaçōes deste padrão aparecem quando a turmalina se concentra quase exclusivamente no nível superior (com pouca turmalina no nível intermediário) ou em bandas mais pobres em turmalina, nas quais falta o nível superior enriquecido nesta fase (bandamento normal incompleto); no primeiro caso, o nível superior aparenta ser uma "banda" independente da quartzofeldspática, simulando-se assim uma alternância de bandas claras e escuras (Foto 5.5). 


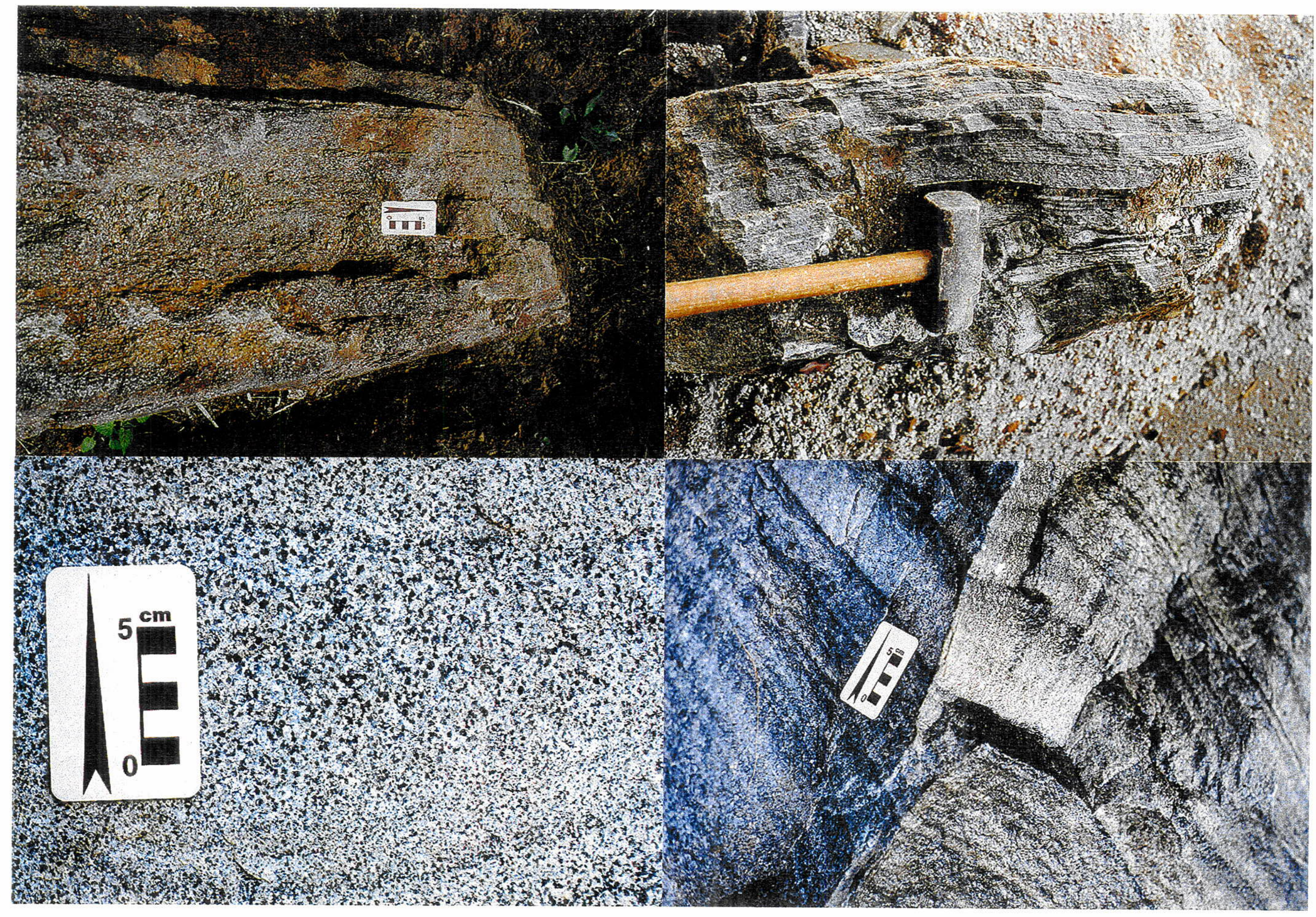




\begin{tabular}{l|l}
5.1 & 5.2 \\
\hline 5.3 & 5.4
\end{tabular}

Foto 5.1. Afloramento de biotita-sillimanita xisto, com foliação vertical; as manchas esbranquiçadas representam áreas com concentração de fibrolita e quartzo (ponto 119, Anexo 3).

Foto 5.2. Rocha cálcio-silicática com bandamento reliquiar regular; as bandas mais claras, em geral, estão enriqueicdas em anfibólio elou carbonatos, enquanto que as mais esverdeadas mostram concentrações maiores de piroxênios, flogopita, etc. (ponto 149, Anexo 3).

Foto 5.3. Fácies bandada, visão de detalhe (comparar com fotografia anterior). (Pedreira Fiore). Ver legenda da Foto 5.3.

Foto 5.4. Fácies bandada na frente de lavra, pedreira Fiore. Cada banda é limitada, no topo, por um nível superior enriquecido em turmalina, por vezes representando um plano de debilidade que controla a ruptura da rocha (visivel no centro da fotografia). A direção da seta assinala o topo (válido também para as outras fotografias com seta). 
Em outras ocasiões, é observada a mesma sequência de níveis, mas com modifícaçðes texturais, seja por manter-se o mesmo tamanho de grão em todos eles, seja por apresentar granodecrescência (bandamentos normal equigranular e normal granodecrescente).

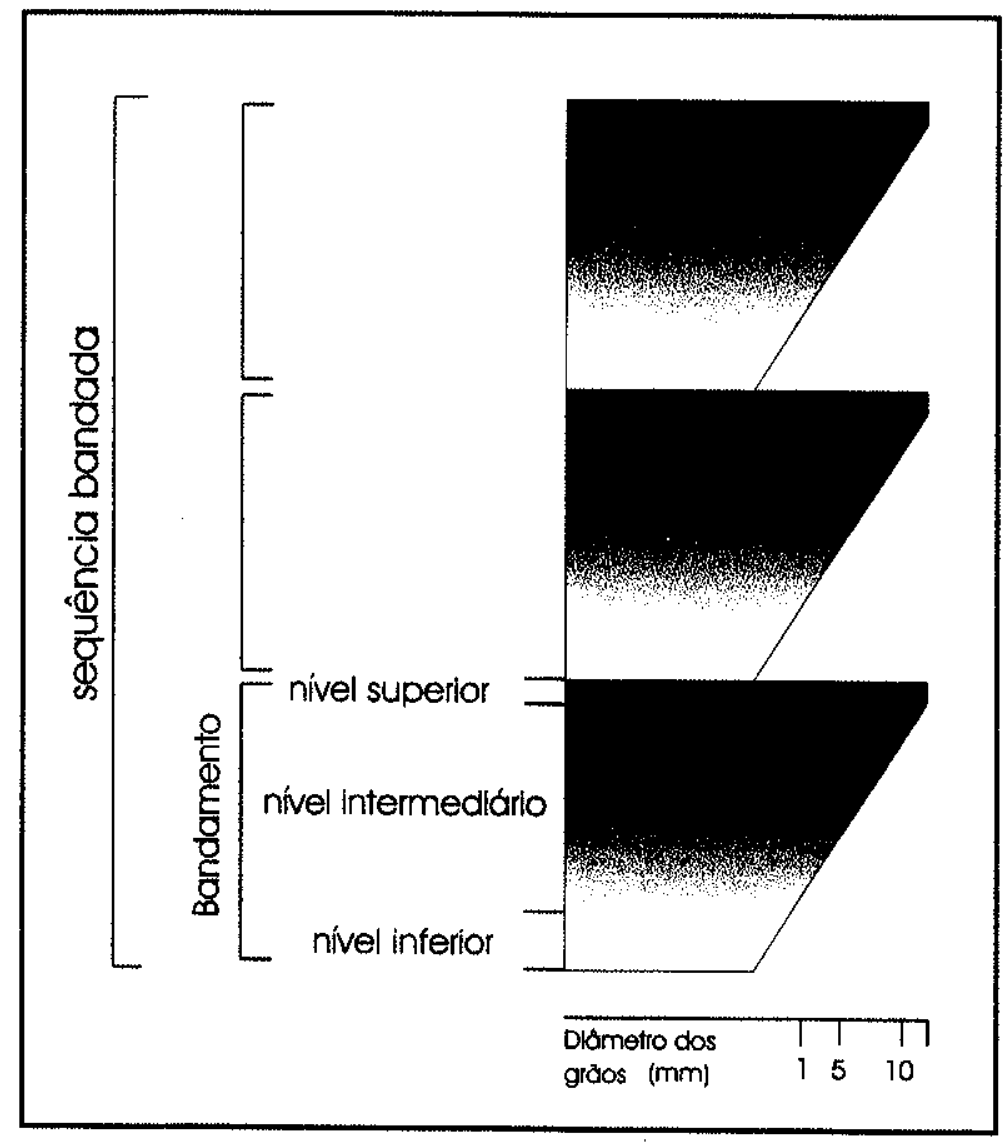

Figura 5.1. Esquema mostrando o bandamento constituído pelos níveis inferior, intermediário e superior, e a superposição desta unidade gerando a sequência "bandada" ou "acamadada". Note que o degrade na figura marca o enriquecimento em turmalina.

Por vezes, os limites entre as bandas mostram aparência gradacional, em parte por estar a turmalina dispersa, mais concentrada no nivel superior da banda inferior, mas ainda aparecendo em proporções significativas no nível inferior da banda imediatamente superior (e.g., Foto 5.6). Esta feição deve ser o resultado da interação entre as duas bandas, durante a etapa magmática de cristalização (por ex., por difusão e comunicação entre as duas bandas, em parte ainda líquidas naquele momento). Uma explicação alternativa seria que esta geometria identificaria um novo tipo de bandamento, em parte inverso por estar a turmalina concentrada em níveis outros que não o superior, ou do tipo "composto", mostrando um nível "intermediário" com teores maiores de turmalina, além do nível superior enriquecido no mesmo mineral. Das duas explicações, prefere-se a primeira, mais simples porque identificaria apenas um único agente como o responsável pela geração do bandamento (ver Capítulo 6). 
Os vários tipos possíveis de bandamento aparecem retratados na Figura 5.2.

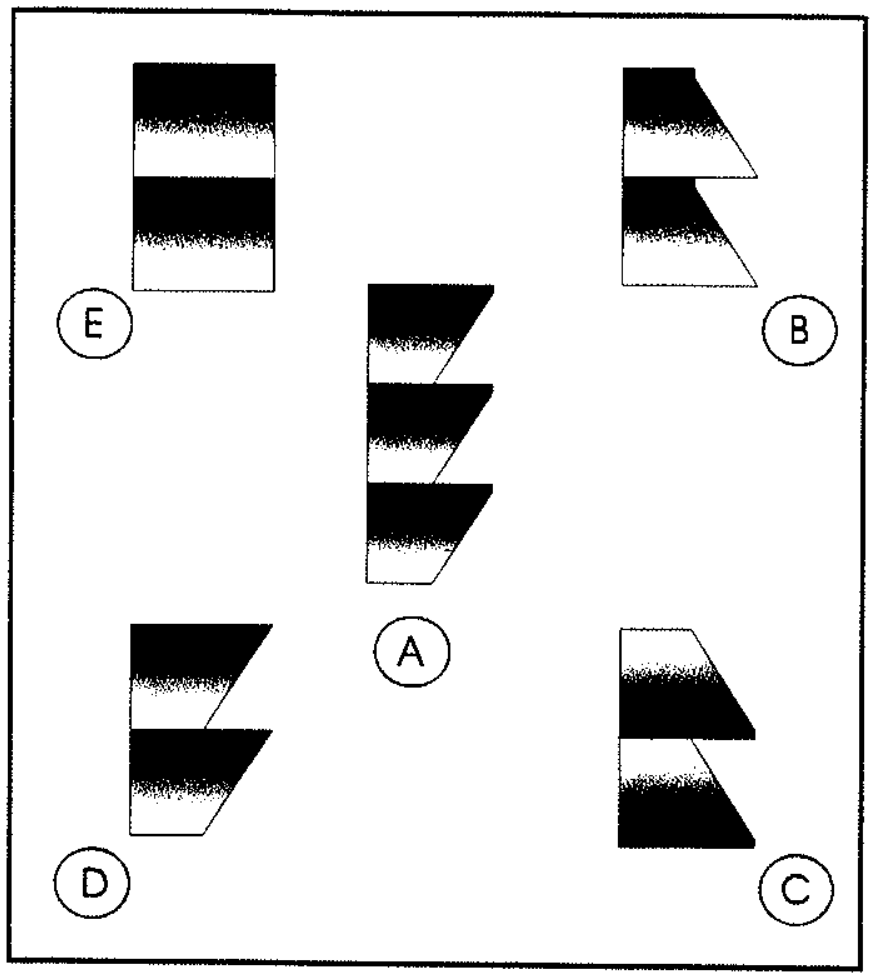

Figura 5.2. Algumas variações do modelo de bandamento reconhecidas no campo. Temse conjunto inequigranular ascendente normal (A), conjunto inequigranular descendente normal (B), conjunto inequigranular descendente invertido (C), conjunto inequigrnular ascendente incompleto (D) e conjunto equigranular normal (E).

Variações modais nos niveis. A fácies bandada mostra variações que não se restringem apenas aos teores de turmalina, mas podem também ser identificadas pelas variações em abundância dos minerais félsicos, principalmente em seções tingidas para separar o feldspato potássico do plagioclásio, com coloração diferencial por meio da técnica do cobaltinitrito de sódio (ver Metodologia, Capítulo 1). Para este trabalho, foram preparadas fatias de rochas cortadas perpendicularmente ao bandamento (e.g., amostras Pe 3-20 e Pe 3-23); para observação ao microscópio, foram obtidas várias lâminas ao longo destes mesmos perfis, descritas na seção seguinte.

As Fotos 5.7 e 5.8 mostram algumas das fatias tingidas, ressaltando-se nelas as variações modais. $\mathrm{O}$ quartzo, equidimensional e cinzento, concentra-se no nível basal, e teores maiores de feldspatos esbranquiçados aparecem no intermediário; por este motivo, os níveis basais apresentam-se com tonalidades cinzentas, os intermediários com cores esbranquiçadas (os dois feldspatos mostram a mesma cor) e os superiores escuros pela presença de turmalina. As fatias tingidas revelam também as variações nos teores relativos de feldspato potássico e plagioclásio. A Foto 5.7 mostra uma banda com um nível inferior, de pouca espessura, enriquecido em quartzo, enquanto que na Foto 5.8 as variações modais são menos visíveis, com um nível basal que se diferencia do intermediário principalmente pelo tamanho dos grãos. 


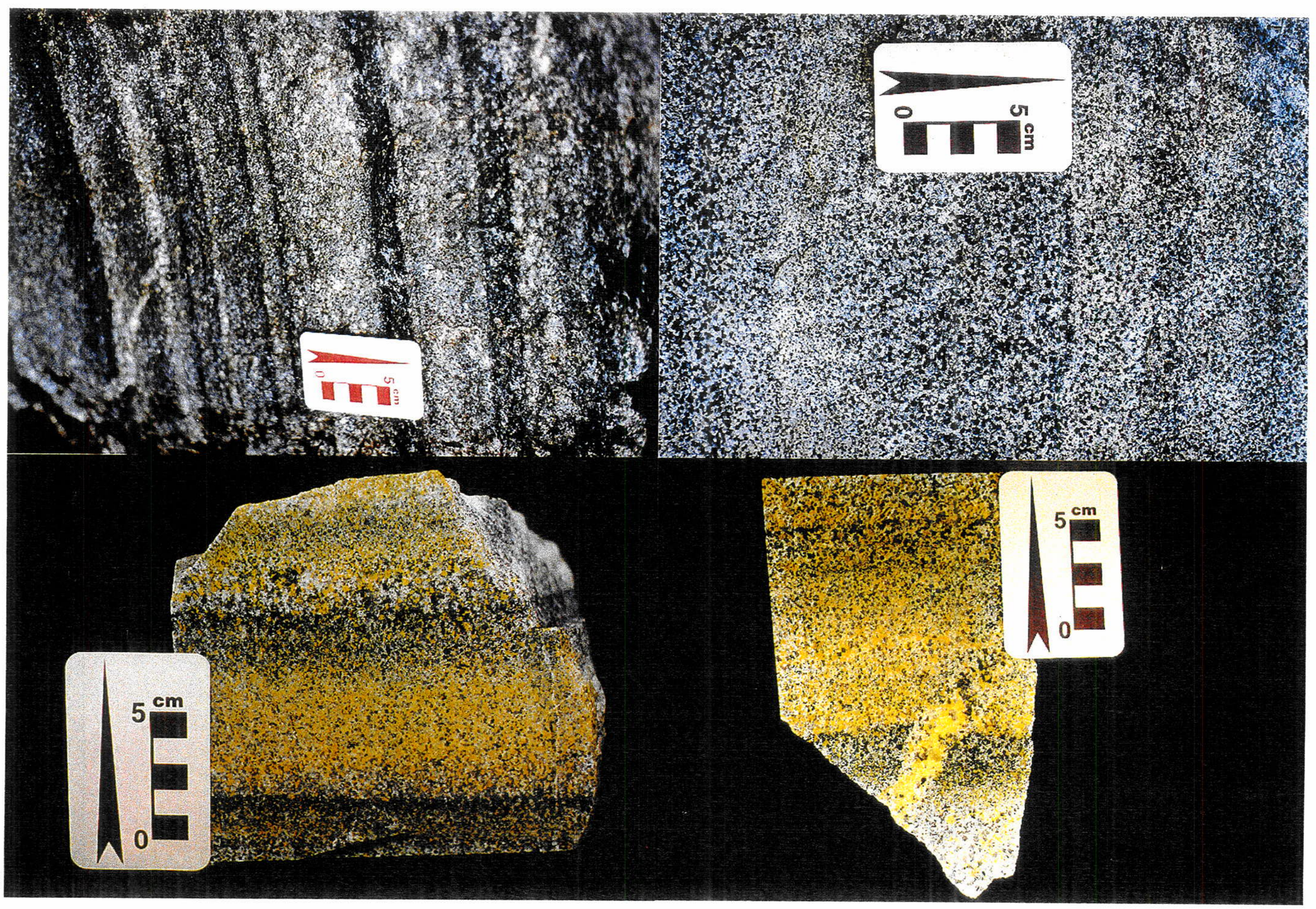




\begin{tabular}{l|l}
5.5 & 5.6 \\
\hline 5.7 & 5.8
\end{tabular}

Foto 5.5. Fácies bandada com turmalina concentrada quase totalmente no nível superior. (Pedreira Fiore). Ver legenda da Foto 5.3.

Foto 5.6. Fácies bandada com limites em parte gradacionais. O limite superior da banda, definido pelo nível superior com turmalina, é brusco e identificado pela ponta da seta; o limite superior do nível inferior, pelo contrário, aparece gradacional e mal definido (parte inferior da fotografia). (Pedreira Fiore). Ver legenda da Foto 5.3.

Foto 5.7. Fatia colorida, identificando uma banda com o nível basal enriquecido em quartzo, o nível intermediário feldspático, e o nível superior com mais turmalina e escasso feldspato potássico (ver também foto 5.7), amostra Pe 2-7, pedreira Botuquara. Ver legenda da Foto 5.3.

Foto 5.8. Fatia colorida, mostrando uma banda e os níveis basal, intermediário e superior, com aparente granocrescência (comparar com Foto 5.8). Amostra Pe 3-20, pedreira Fiore. Ver legenda da Foto 5.3. 
Ao mesmo tempo, o tingimento destaca as variações nos teores dos feldspastos, invisíveis de outra maneira (além da cor idéntica nas duas fases, a geminação no plagioclásio é de observação macroscópica mais dificil), verificando-se claramente nas duas fotografias que o nivel superior com turmalina aparece com predomínio do plagioclásio e invariavelmente com pouco feldspato potássico.

As variações encontradas na amostra Pe 3-20, baseadas em contagem modal em lâminas, aparecem representadas na Figura 5.3, e são consideradas representativas das variações modais na fácies bandada (para maiores detalhes, ver seção seguinte sobre microscopia).

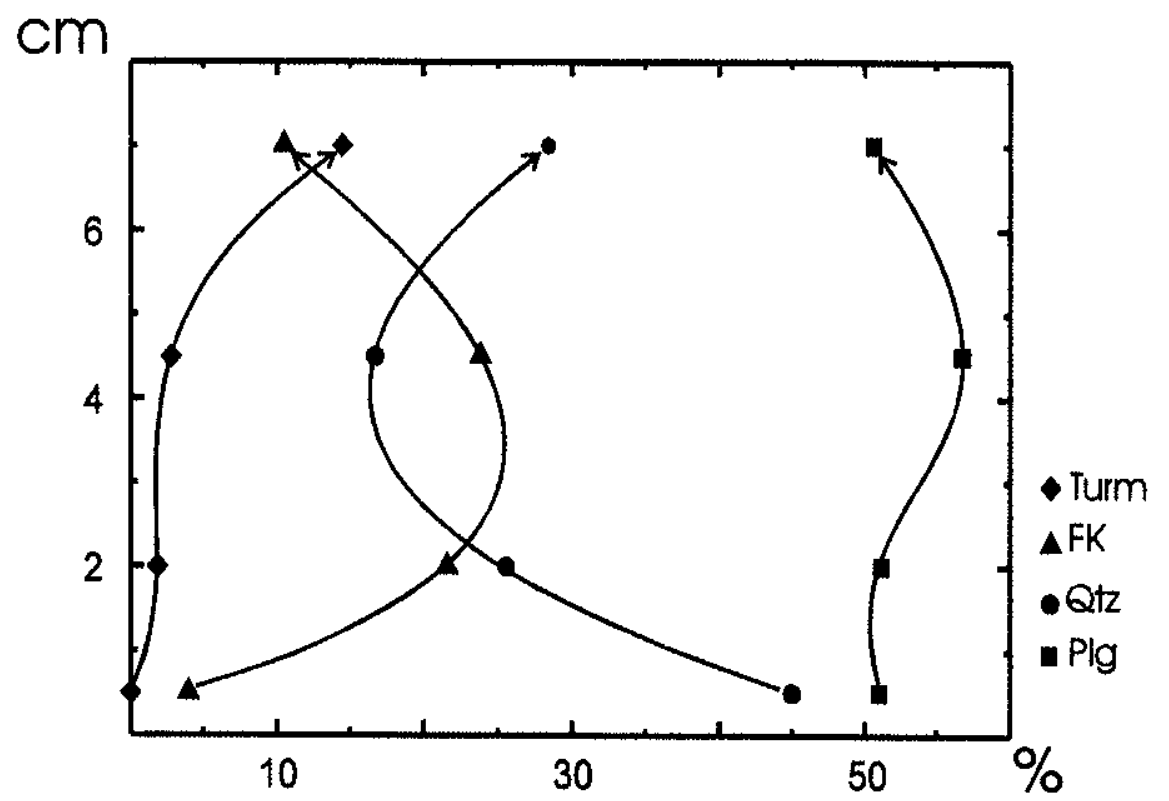

Figura 5.3. Perfil mineralógico transversal à banda (amostra Pe 3-20, ponto 136, Anexo 3) mostrando as principais variações dos minerais; contagem modal em lâminas (ver texto).

Limites entre bandas. Nos casos mais claros, os limites entre bandas estão identificados pelo teto do nível superior e são claramente visiveis, retilíneos e contínuos (e.g., Fotos 5.3 a 5.5). Frequentemente, entretanto, estes limites são ora irregulares, ora difusos. A Foto 5.6 mostra uma banda de aspecto "composto", com limite superior claro, mas cujo contato com a banda infrajacente é difuso e irregular (provavelmente, como indicado acima, porque houve vigorosa interação entre ambas bandas durante a etapa de cristalização, apagando-se então em parte os limites entre elas). Limites tanto irregulares como difusos entre bandas são também observados na Foto 5.9.

A fácies pegmatóide interna: relações com o bandamento. A observação de campo indica que diques e veios de turmalina pegmatitos externos (ver item 4.2.4) aparecem quase sempre como corpos aparentemente independentes, sem relações de contato diretas com turmalina granitos (e.g., Foto 4.8). Os pegmatitos encontrados no interior das bossas de turmalina granitos, entretanto, estão intimamente relacionados com 


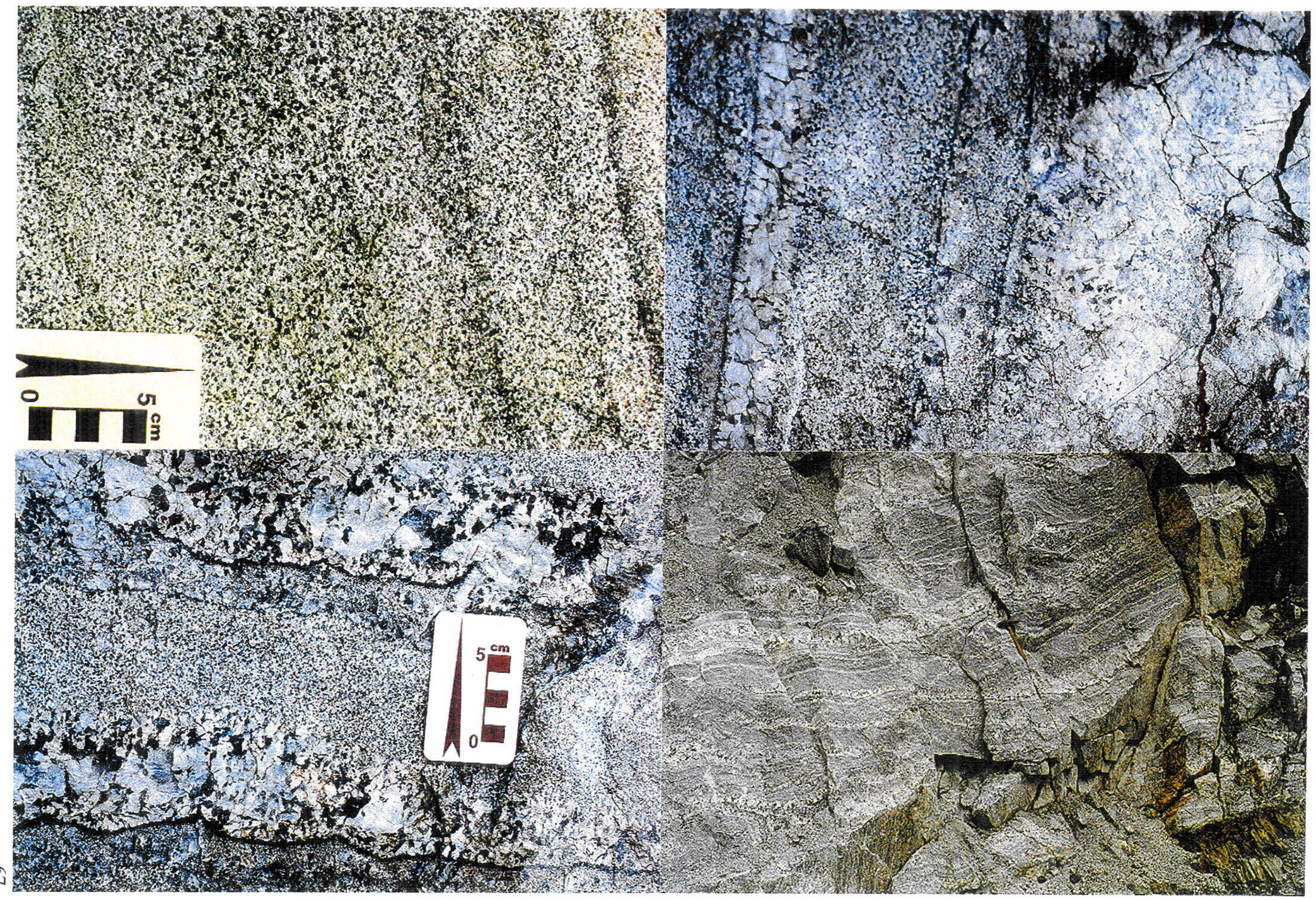




\begin{tabular}{l|l}
5.9 & 5.10 \\
\hline 5.11 & 5.12
\end{tabular}

Foto 5.9. Fácies bandada na frente de lavra. Observar limites difusos a irregulares-sinuosos entre as bandas, por vezes com gradações (pedreira Fiore). Ver legenda da Foto 5.3.

Foto 5.10. Fácies bandada e veios concordantes de pegmatóides (fácies pegmatóide interna) na frente de lavra. Observar os contatos retilíneos entre as bandas e os veios, as diferenças na granulometria, e a disposição diferente das turmalinas. (Pedreira Fiore). Topo: parte superior da fotografia.

Foto 5.11. Fácies bandada e veios concordantes de pegmatóides. Observar os contatos sinuosos na parte inferior do veio, e irregular-difuso na sua parte superior, conjuntamente com as concentrações da turmalina nas bordas. (Pedreira Fiore). Ver legenda da Foto 5.3.

Foto 5.12. Fácies bandada e veios concordantes a subconcordantes de pegmatóides, na frente de lavra (pedreira Botuquara). Topo: parte superior da fotografia. 
a fácies bandada. Esta fácies pegmatóide interna aparece morfologicamente sob três formas: veios concordantes a subconcordantes, veios discordantes, e corpos irregulares a tabulares ("diques") maiores. Os veios (concordantes ou não) mostram espessuras milimétricas ou centimétricas, os corpos maiores (bolsões e "diques") espessuras maiores, por vezes até métricas ou decamétricas (ver item 4.2.4).

As relações aparecem identificadas nos Fotos 5.10 a 5.12, mostrando os veios concordantes que acompanham o bandamento da fácies bandada, com contatos ora retilíneos (Foto 5.10), ora ondulados a irregulares (Fotos 5.11 e 5.12). Estes veios mostram quartzo, feldspatos e turmalina milimétricos a centimétricos; a última aparece com distribuição irregular, concentrada na base do veio onde forma uma conspícua borda (e.g., Fotos 5.10, 5.11), e também na parte superior, como cristais com crescimento normal aos limites das bandas (e.g., Foto 5.11). A regularidade das relações entre os níveis da banda e o percurso do veio pegmatítico concordante sugere que existe íntima relação genética entre ambas, tal vez porque os veios representam resíduo magmático hiperfluido concentrado em níveis preferenciais da banda.

Por outro lado, a Foto 5.13 estabelece claramente a relação entre os veios corcordantes e os discordantes, estes enraizados nos primeiros; ambos apresentam sempre a mesma mineralogia e espessuras similares, e alguns dos veios discordantes também mostram concentrações irregulares de turmalina (e.g., preferencialmente em ambas as bordas, Foto 5.13). Estes líquidos pegmatíticos são magmas hiperfluidos, com "liquidus" de baixa temperatura e que devem se mobilizar com maior facilidade que os magmas graníticos que formam a fácies bandada. Deste modo, os pegmatóides discordantes representariam apenas líquidos antes contidos nas bandas, agora mobilizados e injetados ao longo de planos preferenciais. Por um mecanismo de "filter pressing", ou similar, a mobilização dos veios e o crescimento do seu volume por adições e concentração em regiões estruturalmente favoráveis (e.g., zonas de cisalhamento) geraria os bolsões e "diques" maiores, tão abundantes em algumas pedreiras (e.g., nas pedreiras 1a e 1b). A Foto 5.14 mostra este estágio final: porções de fácies bandada, em parte contendo veios concordantes de pegmatóides e alguns dos discordantes, e uma zona tabular vertical de espessura métrica com estrutura caótica, aparentemente formada por adições sucessivas de material pegmatítico.

\section{Aspectos microscópicos}

As observações ao microscópio, discutidas a seguir, refletem as feições já observadas nos afloramentos e na amostra de mão. A fácies bandada, no seu conjunto, mostra como textura predominante a hipidiomórfica equigranular a levemente inequigranular, com os dois feldspatos, quartzo e turmalina como fases principais; a granada é o mineral acessório mais frequentemente encontrado.

A contagem modal nos vários níveis das bandas foram realizadas em lâminas selecionadas e retiradas de amostras previamente tingidas (Pe 3-20 e Pe 3-23). Nestas amostras as bandas estão bem desenvolvidas (espessuras de até $7 \mathrm{~cm}$ ), observando-se com clareza os distintos níveis. As seções foram posicionadas paralelamente ao bandamento, representando as variações encontradas nos vários níveis: uma seção foi realizada a $0,5 \mathrm{~cm}$ 


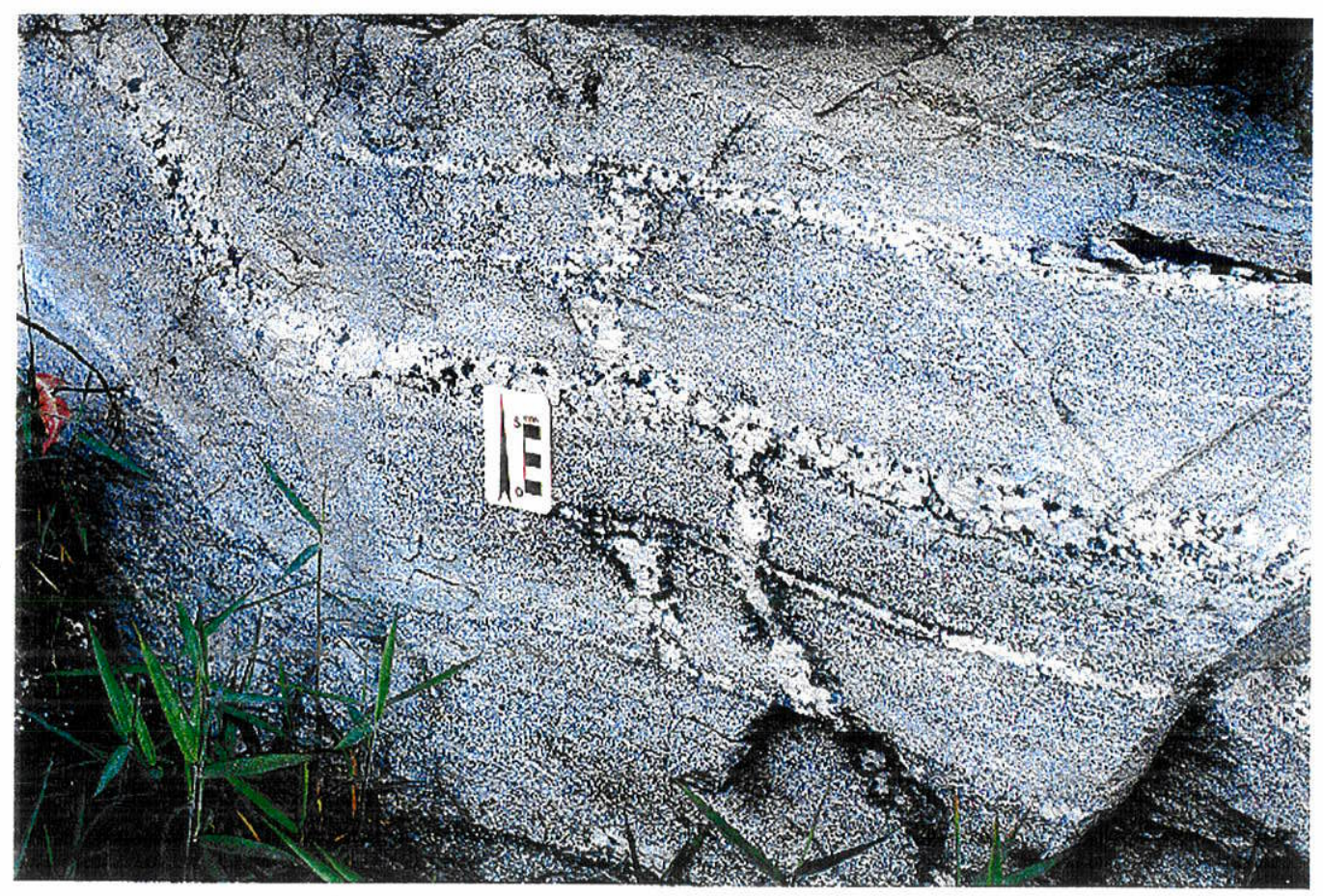

Foto 5.13. Fácies bandada e veios pegmatóides concordantes em relação direta com veios discordantes, na frente de lavra (pedreira Fiore). Observar as "raizes" dos veios discordantes, emanadas dos veios concordantes, e a disposição das turmalinas nos veios. Ver legenda da Figura 9.3.

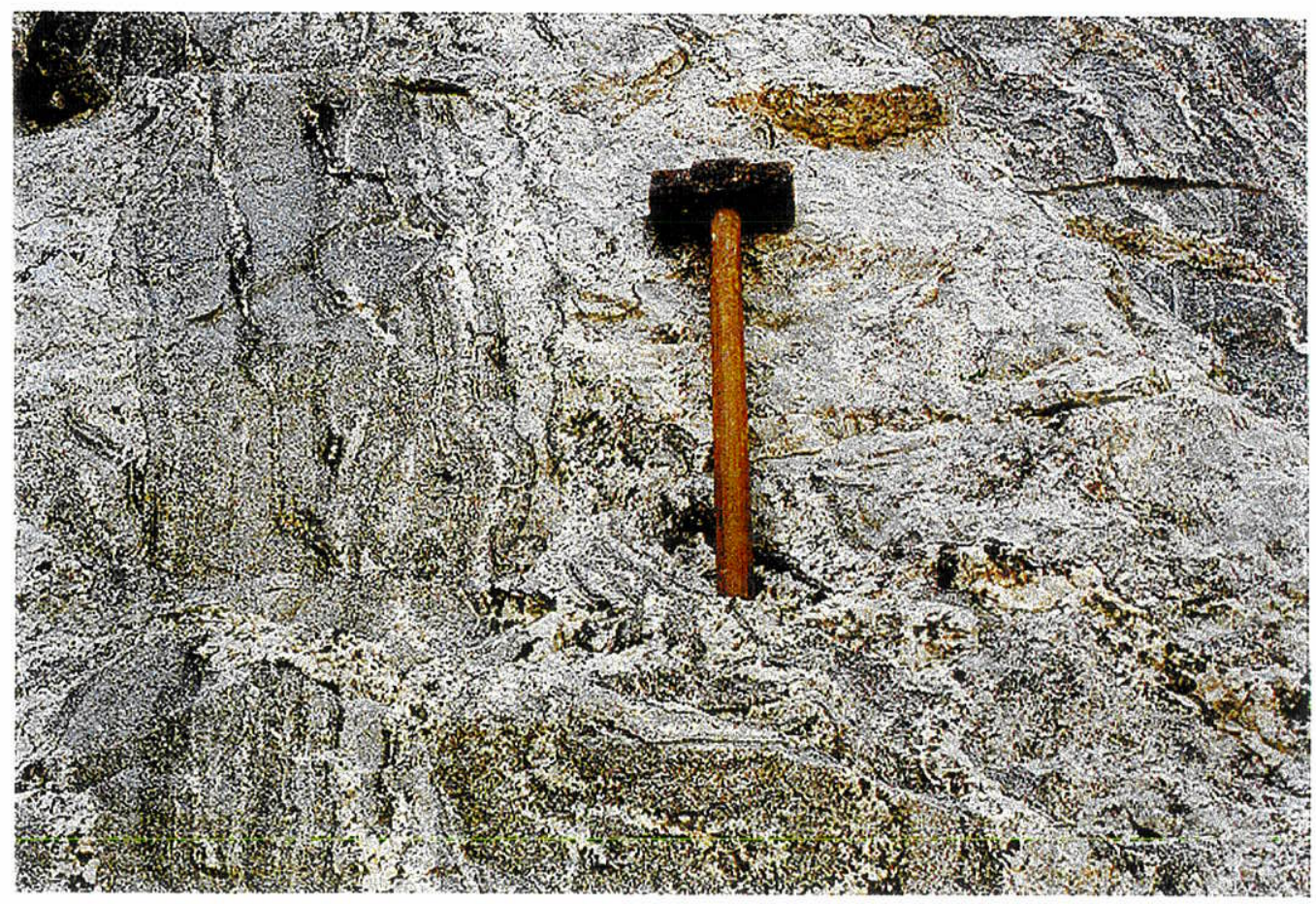

Foto 5.14. Fácies bandada e veios pegmatóides concordantes e discordantes, em contato com um "dique"de espessura métrica. A fácies bandada aparece com as bandas em posição vertacal por deformação, e o dique mostra estrutura interna caótica, sugerindo preenchimento e coleta de material pegmatítico por acreção contínua. (pedreira Dellantônia). Topo: parte superior da fotografia. 
da base da banda (nível basal), duas seções a aproximadamente 1/3 e 2/3 da espessura total da banda (representando seções do nível intermediário) e a última seção cortando o topo da banda, mostrando o nível enriquecido em turmalina. Os resultados da contagem, ao microscópio, são apresentados na Tabela 5.1 e lançadas na Figura 5.4. Os resultados mostram que as bandas são, composicionalmente, granodioritos, com pequenas variações modais nos diferentes níveis: mais ricos em quartzo nos níveis basais, com mais plagioclásio (mais "tonalíticos") nos níveis superiores.

Contrariamente ao esperado, a fácies bandada no seu conjunto representa um sistema composicional aparentemente diferente do da fácies homogênea, que seria claramente mais rica em feldspato potássico (ver Figura 5.4).

A contagem modal realizada em lâminas da amostra $P e$ 3-20 aparece representada em perfil na Figura 5.3. A base e o topo são enriquecidos em quartzo, mais o primeiro que o segundo, e o feldspato potássico é mais abundante no nível intermediário. A turmalina, obviamente, aparece principalmente no topo, com rápida diminuição nos níveis intermediários (e virtual ausência na base). Em função destas variações modais, os dados modais dos três níveis basal, intermediário e superior de uma mesma banda desenham um pronunciado "loop" na representação modal Q-FK-P (Figura 5.4).

De maneira geral, os grãos de feldspato potássico mostram-se como cristais tabulares a irregulares, com extinção irregular, nem sempre apresentando geminação em grade; a de Carlsbad é rara. Mostra ainda pertitas filamentosas. Como inclusões tem-se prismas de turmalina e pequenos cristais anédricos de plagioclásio. Os grãos ocorrem com maior frequência no intervalo granulométrico entre 0,5 e $1,0 \mathrm{~mm}$ nos niveis de base e intermediário, chegando no nível mais superior a desenvolver grãos de até $3,5 \mathrm{~mm}$ (modelo de banda com granocrescência). Este mineral mostra-se sempre intersticial, com bordas bastantes sinuosas, desenvolvendo grãos mais equidimensionais no centro das bandas.

O plagioclásio, ripiforme, euédrico a subédrico, apresenta tênue zoneamento, leve alteração, linhas de crescimento e marcada geminação polissintética albita e periclínio. Como inclusões apresenta prismas de turmalina e raro quartzo irregular. No nível inferior predominam grãos subédricos e finos, enquanto que no intermediário os grãos são subédricos a euédricos, finos a médios (intervalo entre 0,5 e $1,5 \mathrm{~mm}$ ). No topo aparecem os grãos maiores, subédricos a xenomórficos (1,0 a $3,0 \mathrm{~mm}$ ). De maneira geral, são os grãos menores em cada nível os que apresentam as lamelas da geminação melhor marcadas.

O quartzo, irregular a equidimensional, mostra-se sempre tensionado, com extinção ondulante moderada a forte, por vezes individualizando subgrãos. No nível de base os grãos são equidimensionais, subédricos, com granulação mais frequente no intervalo entre 0,5 e $1,5 \mathrm{~mm}$. Nos níveis intermediários, onde este mineral apresenta-se em menor quantidade, os grãos são mais irregulares e com tendência mais intersticial, de contornos sinuosos; a extinção é ondulante, porem não chega a desenvolver subgrãos. No nível superior, o quartzo predominante é irregular, de maior tamanho, contornos sinuosos, por vezes equigranular subédrico, com a extinção ondulante e presença de subgrãos. 
Tabela 5.1. Dados modais para os turmalina granitos de Perus, fácies bandada e homogênea (PE).

\begin{tabular}{lcccccc}
\hline Amostra & Quartzo & $\begin{array}{c}\text { Feldspato } \\
\text { Potássico }\end{array}$ & Plagioclásio & Turmalina & Granada & Muscovita \\
\hline PE3 - 17a & 44,69 & 10,06 & 35,56 & 9,37 & 0,19 & 0,13 \\
PE3 - 17b & 13,88 & 28,44 & 53,98 & 3,63 & 0,13 & 0 \\
PE3 - 20s & 38,09 & 3,30 & 40,86 & 16,77 & 0,98 & 0 \\
PE3 - 20a & 41,82 & 16,06 & 41,37 & 0,75 & 0 & 0 \\
PE3 - 20b & 25,56 & 21,56 & 51,11 & 1,78 & 0 & 0 \\
PE3 - 20c & 16,73 & 23,77 & 56,73 & 2,78 & 0 & 0 \\
PE3 - 20d & 24,94 & 9,88 & 50,50 & 14,44 & 0,25 & 0 \\
PE3 - 23a & 25,69 & 22,38 & 48,38 & 3,00 & 0 & 0,56 \\
PE3 - 23b & 21,13 & 27,00 & 49,88 & 1,56 & 0,13 & 0,31 \\
PE3 - 23c & 22,68 & 13,11 & 59,35 & 3,60 & 0,68 & 0,56 \\
PE3 - 23d & 27,36 & 16,21 & 48,21 & 7,57 & 0,57 & 0,07 \\
PE3 - 23f & 25,50 & 12,14 & 58,21 & 4,14 & 0 & 0 \\
PE2 - 11a* & 35,4 & 37,4 & 22,2 & 3,1 & 1,7 & 0 \\
PE2 - 11b* & 35,87 & 34,19 & 26,94 & 3,00 & 0 & 0 \\
PE1 - 9* & 32,25 & 34,75 & 28,13 & 4,50 & 0,38 & 0 \\
PE3 - 6 & 29,54 & 17,99 & 47,98 & 4,50 & 0 & 0 \\
\hline
\end{tabular}

*- fácies homogênea 


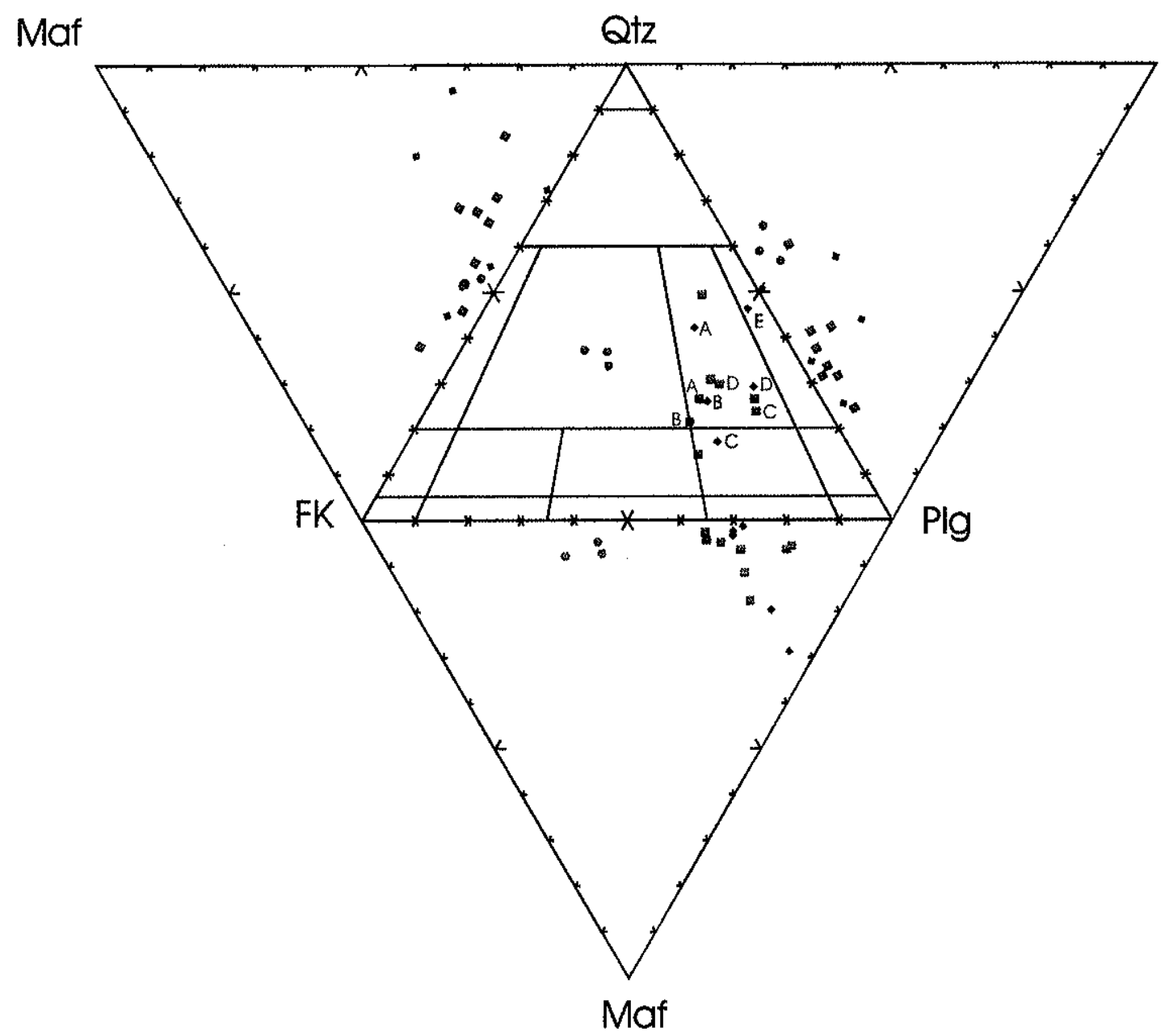

Figura 5.4. Diagrama modal Q-A-P-M para os turmalina granitos. A fácies homogênea é representada pelos circulos (em azul), e a bandada pelos quadrados (em vermelho) e losangos (em verde). As letras ao lado das representações marcam os dados modais obtidos em distintos níveis da mesma banda: inferior ( $A$ e $E)$, intermediário $(B$ e $C$ ) e superior (D). 
A turmalina aparece geralmente como prismas idiomórficos, em parte de pequenos tamanhos e inclusa em outros minerais; mais raramente, é observada como grãos intersticiais. É fortemente pleocróica (x: verde oliva escura; $z$ : amarelo esverdeado claro), frequentemente mostrando zonalidade oscilante (núcleo mais escuro). Predomina a variedade schorlita. A zonalidade é mais marcada nas seções que cortam o seu eixo $c$, com uma sucessão de faixas pleocróicas em tons amarelo-verde acastanhado e incolor-azul claro, repetidas duas ou três vezes. As suas características são as mesmas, tanto no nível intermediário como no topo, notando-se entretanto marcado aumento nas suas dimensões, (0,5 a $1,0 \mathrm{~mm}$ nos níveis inferiores e intermediários, até 0,6 a $2,5 \mathrm{~mm}$ no topo; modelo de banda com granocrescência).

Localmente são observadas faixas de maior deformação na rocha, visíveis principalmente pela intensa recristalização do quartzo, que ocorre então como mosaicos envolvendo relitos de cristais fraturados de turmalina e feldspato potássico, além de grãos de plagioclásio exibindo as suas lamelas de geminação dobradas.

As feições texturais e composicionais que ocorrem numa banda aparecem ilustradas na seção trasnversal da Foto $15(\mathrm{a}, \mathrm{b})$, com o nível com turmalina marcando o topo da banda (e a base da banda suprajacente), com gradação para o nível intermediário, observado na parte inferior da ilustração. Nas Fotos 16 a 19 são representadas seções paralelas ao bandamento, ilustrando o nível basal (Foto 16), o nivel intermediário (Foto 17) e o nível superior (Fotos 18 e 19). Neste conjunto de fotografia observa-se claramente que as turmalinas da fácies bandada não estão orientadas; pelo contrário, as turmalinas que aparecem em veios e "diques" da fácies pegmatóide interna (e até da externa) se posicionam, com frequência, perpendicularmente ao comprimento dessas estruturas.

\subsubsection{Fácies homogênea}

A rocha mostra estrutura maciça equigranular e granulação de fina a média, cor geral esbranquiçada, com manchas escuras identificadoras da turmalina (Fotos 5.20 e 5.21). As relações de campo sugerem que a fácies homogênea, sempre de ocorrência restrita e de distribuição muito irregular, é o resultado de processos de homogeneização de regiões com fácies bandada predominante, por meio de um processo que apaga os limites entre bandas (?). Assim, na Foto 5.20 é observada a fácies homogênea, substituída na parte inferior por uma sequência bandada; um veio concordante de pegmatito separa as duas porções. Na porção mais homogênea, nesta fotografia, o bandado não é preservado, mas ainda é observada uma distribuição algo heterogênea dos grãos de turmalina, em parte enfatizada pela presença de manchas claras (com ausência de turmalina).

A textura observada em lâmina é hipidiomórfica equigranular a levemente inequigranular, de granulação fina a media (dimensões de 0,5 a 2-3 $\mathrm{mm}$ ) com feldspato potássico predominante, plagioclásio, quartzo e turmalina; como acessórios, ocorrem granada e micas claras. A composição modal é sieno- a monzogranítica (Tabela 5.1, Figura 5.4), diferente portanto da composição das fácies bandadas.

O feldspato potássico mostra frequentemente bordas irregulares, geminação cruzada e pertitas filiformes, estas geralmente em proporção muito pequena; mas raramente ocorre substituição por plagioclásio (albita tipo "chess-board"). Como inclusð̃es 

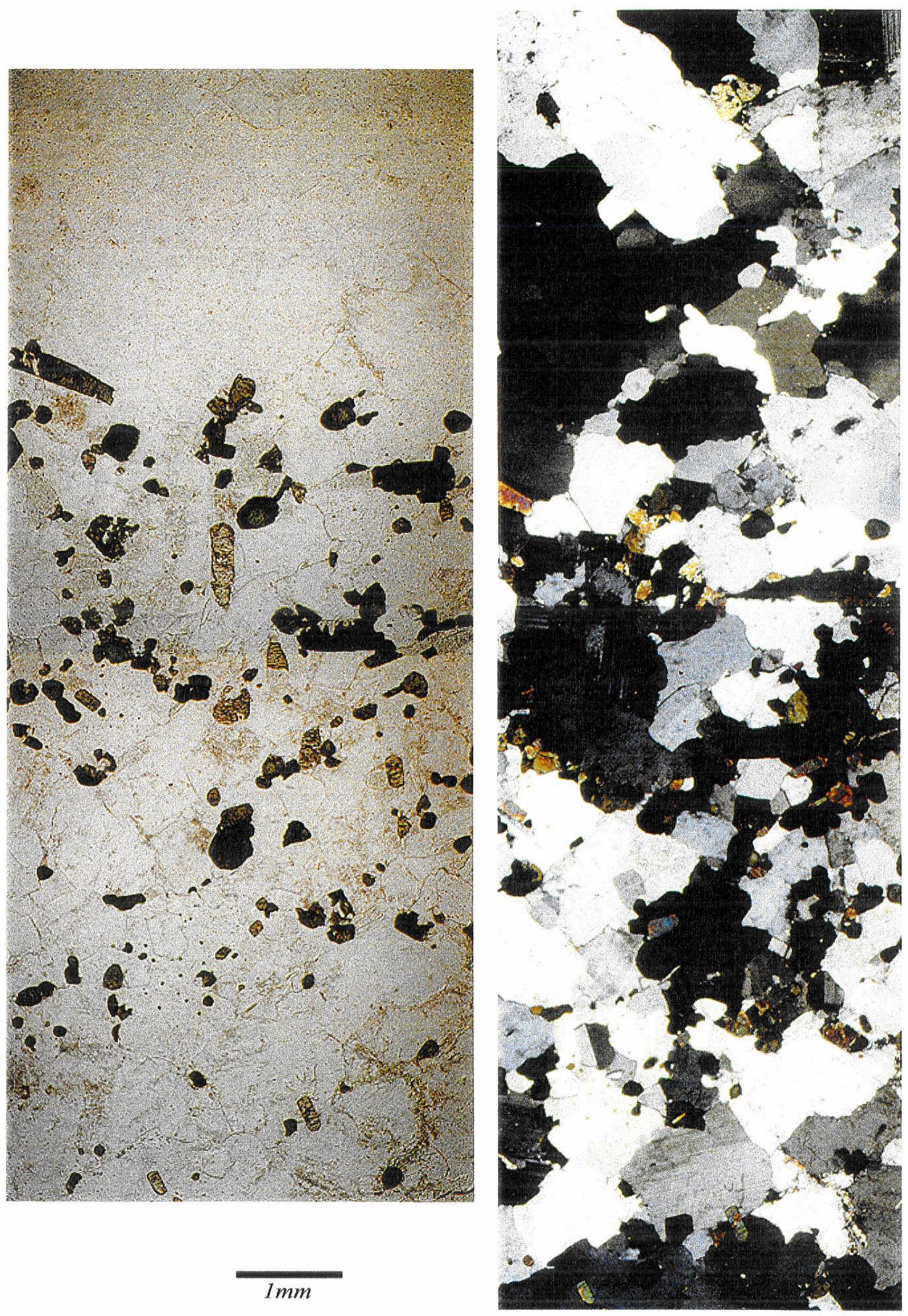
$5.15 a$

$5.15 b$

Foto 5.15. Seções transversais ao bandamento, mostrando a distribuição dos minerais, nícois descruzados a) e nicois cruzado b). Nota-se o incremento gradativo da turmalina, do nível intermediário para o superior, e a interrupção brusca marcando o início do nível basal da banda suprajacente. Amostra Pe 3-6, pedreira Fiore. 


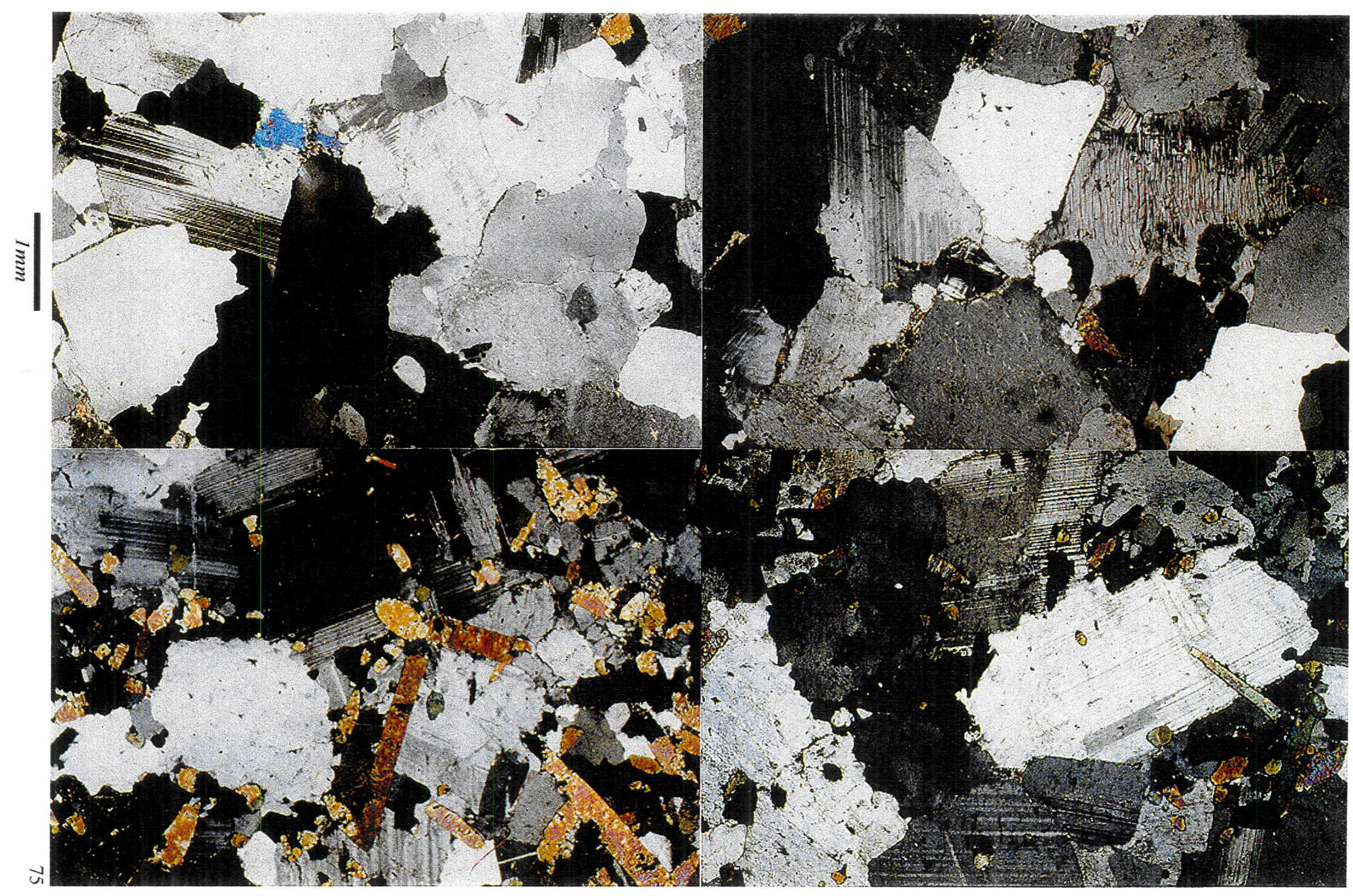




\begin{tabular}{l|l}
5.16 & 5.17 \\
\hline 5.18 & 5.19
\end{tabular}

Foto 5.16. Fácies bandada, nível inferior (nícois cruzados). Amostra Pe 3-20, pedreira Fiore. (Seção paralela ao bandamento)

Foto 5.17. Fácies bandada, nível intermediário, com maior abundância de feldspato potássico (nícois cruzados). Amostra Pe 3-20, pedreira Fiore. (Seção paralela ao bandamento)

Foto 5.18. Fácies bandada, nível superior com turmalina e proporção maior de plagioclásio. Amostra Pe 3-20, pedreira Fiore. (Seção paralela ao bandamento)

Foto 5.19. Fácies bandada, nível superior com turmalina e maiores proporções de plagioclásio. Amostra Pe 3-20, pedreira Fiore. (Seção paralela ao bandamento) 
tem-se prismas de turmalina, quartzo irregular e em gotas, e por vez também plagioclásio zonado.

O plagioclásio, com geminação predominante de lamelas finas (lei da albita), mostra-se levemente zonado, com bordas mais albíticas, por vezes largas, e núcleos em geral homogêneos. As inclusões, mais raras que no outro feldspato, são de turmalina idiomórfica e quartzo equidimensional.

O quartzo é irregular a equidimensional, de contornos sinuosos, que ocorre frequentemente como conjunto de vários grãos (em parte por recristalização).

A turmalina é idiomórfica, prismática ( $\mathrm{x}$ : verde oliva escura; $\mathrm{z}$ : amarelo esverdeado claro), frequentemente com zonalidade oscilante (núcleo mais escuro ). A variedade predominante é a schorlita.

A granada é equidimensional idiomórfica a subdiomórfica. As de maiores dimensões $(2,5 \mathrm{~mm})$ mostram contornos não contínuos e inclusões (geralmente de quartzo).

Raramente, são observadas algumas lâminas de micas claras tardias, de crescimento intersticial e hábito radiado.

Como sinais de alteração deutérica incipiente ocorrem pequenas lâminas de sericita e algum carbonato em grãos de plagioclásio; os feldspatos potássicos estão frescos.

A deformação se faz presente nos plagioclásio através da geminação muito fina, em alguns casos com lamelas dobradas e com interrupções; alguns grãos estão claramente quebrados. No quartzo tem-se quase sempre extinção ondulante e em mosaico.

\subsubsection{Fácies pegmatóide interna}

Esta fácies mostra grãos de dimensões centimétricas a decamétricas, tendo-sc: registrado no passado ocorrências de grãos de quartzo, feldspato e principalmente de turmalina (rósea a preta) de 10 a $20-30 \mathrm{~cm}$ de tamanho, que se concentravam, aparentemente, nas partes internas dos corpos, hoje desaparecidas. É dificil estimar a sua composição, que parece ser, em média, a de sienogranitos ou até de álcali-feldspato granitos, pelo predomínio completo do feldspato potássico; o plagioclásio parece ser muito mais raro nesta façies, principalmente nas porções com tamanhos mais avantajados. As Fotos 5.22 e 5.23 mostram alguns aspectos mineralógicos e texturais, tais como o intercrescimento gráfico em grãos maiores de feldspato potássico (encontrados com frequência na pedreira Botuquara), e o hábito prismático e o predomínio da turmalina preta sobre as outras variedades (rósea e bege-esverdeada, a última mais rara), fase esta de distribuição ora bastante uniforme (Foto 5.22), ora concentrada em bandas ou áreas de crescimento preferencial (e.g., faixas, bordas externas de veios e "diques" de pegmatitos, etc.) 


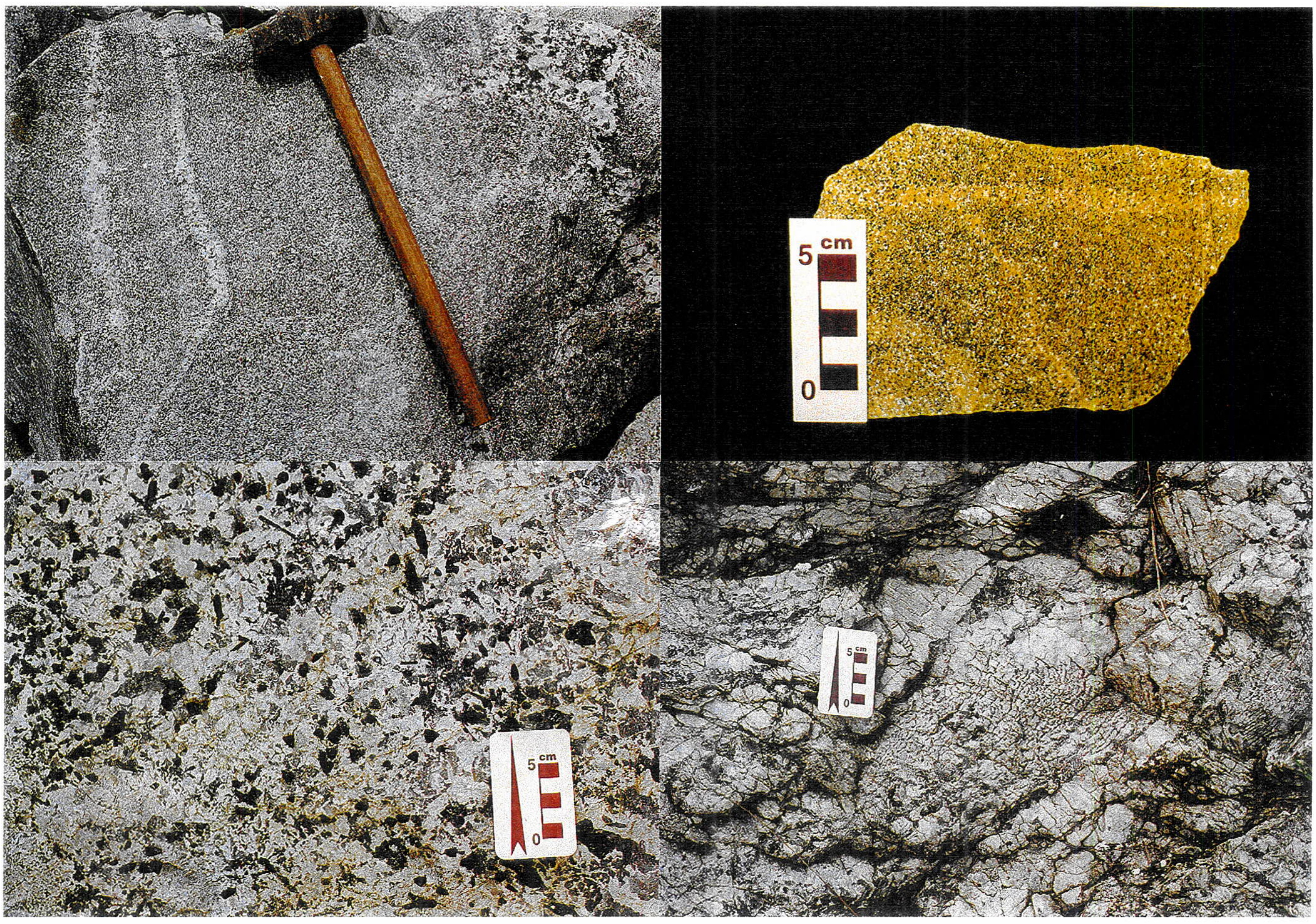




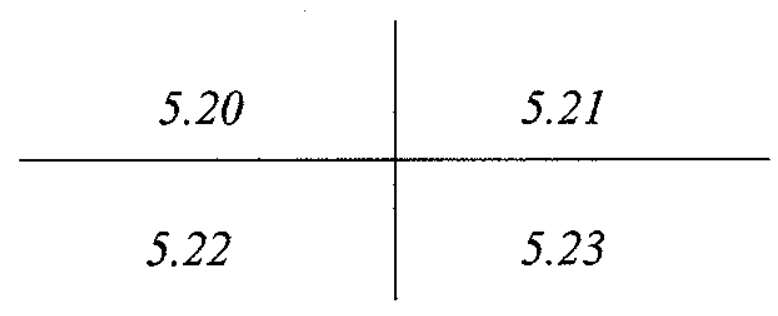

Foto 5.20. Fácies homogênea na frente de lavra (pedreira Botuquara). Esta exposição sugere que a fácies homogênea é gerada por homogeneização da fácies bandada (parte inferior da fotografia; ver texto). Ver legenda da Figura 5.3.

Foto 5.21. Fácies homogênea em fatia de rocha (amostra Pe 1-9, pedreira Dellantônia).

Foto 5.22. Feldspato de dimensões centimétricas com intercrescimento gráfico na fácies pegmatóide interna (frente de lavra, pedreira Dellantônia).

Foto 5.23. Fácies pegmatóide interna na frente de lavra (ver texto). Pedreira Fiore. 


\subsection{OS GRANITÓIDES DOS CORPOS MAIORES}

\subsubsection{Granitóide Cantareira}

A rocha encontrada nesta porção do batólito, amostrada principalmente nas duas pedreiras Embu e Panorama, é uma fácies com poucos fenocristais de feldspatos, que deve corresponder à chamada fácies Pirituba (e.g., Dantas, 1990). Mostra textura porfirítica com reduzido número de megacristais de feldspato potássico, cujo tamanho chega até 35 $\mathrm{mm}$. A matriz é fina a grossa, inequigranular e hipidiomórfica, constituída por cristais de plagioclásio, quartzo e feldspato potássico intersticial (Foto 5.24). A composição é granítica a quartzo-monzonítica (Tabela 5.2, Figura 5.5). A biotita, verde-acastanhada, apresenta-se como agregados, com titanita euédrica, apatita e opacos; os agregados estão orientados e marcam uma foliação incipiente na rocha. É destacada ainda a ausência de hornblenda na associação mineral.

Ao microscópio, os megacristais de feldspato potássico mostram-se frescos, tabulares, portando mirmequitas nas bordas sinuosas. A geminação Carlsbad é frequente, ocorrendo em alguns grãos em associação com a geminação cruzada. As pertitas presentes são filamentosas. Como inclusões ocorre plagioclásio subédrico alterado, mais no centro do megacristal, titanita euédrica e nas bordas gotas de quartzo, em parte marcando linhas de crescimento. O feldspato potássico intersticial mostra-se como cristais mais límpidos, com geminações cruzada e Carlsbad, e pertitas. Inclusos ocorrem cristais euédricos e subédricos de titanita e plagioclásio, quartzo em gota e biotita.

O plagioclásio, alongado a equidimensional, medindo até $3 \mathrm{~mm}$, subédrico, apresenta-se zonado (e.g., amostras CA 9-3A, CA 9-3B e CA 9-4). Muito dos grãos mostram bordas irregulares mais albíticas, e mirmequitas. A geminação da albita (sempre fina) é comum, e a de periclínio é mais rara. Feições de desmistura são restritas, ocorrendo antipertitas irregulares somente em duas lâminas (CA 9-5, mais abundante, e CA 9-3A). Como inclusões tem-se titanita euédrica, biotita irregular e gotas de quartzo.

Os grãos anédricos cie quartzo não excedem $5,0 \mathrm{~mm}$, apresentam-se na maioria das vezes com bordas sinuosas. Formam geralmente agregados, mostrando grãos de contornos sinuosos-lobulados, resultado de deformação com pouca recristalização posterior.

A biotita é placóide-laminar, subédrica a anédrica, com dimensões menores que $1,5 \mathrm{~mm}$. Apresenta pleocroismo variando de amarelo claro a verde acastanhado. Como inclusões ocorrem apatita e subordinadamente titanita e zircão, este último gerando halos pleocróico.

A titanita, bastante abundante, apresenta-se como cristais euédricos de dimensões entre $1,0-0,4 \mathrm{~mm}$. Ocorre normalmente como inclusão ou próxima de cristais de biotita $\mathrm{e}$ minerais félsicos da rocha, sempre associada com minerais opacos e apatita, apresentando ainda este último incluso. A allanita, de ocorrência restrita (no máximo 2 grãos por lâmina), apresenta-se como cristais euédricos medindo até $1 \mathrm{~mm}$, sempre associada à biotita e por vezes à titanita, apatita e minerais opacos. $\mathrm{O}$ zircão, euédrico e submilimétrico, é raro. A apatita mostra-se como prismas euédrico com dimensões de até 
$0,5 \mathrm{~mm}$. O epidoto ocorre como pequenos cristais euédricos a subédricos, isolados, de 0,3 $\mathrm{mm}$.

Como produto de alteração é comum o aparecimento de epidoto, sericita, carbonato e clorita. Os três primeiros são frequentemente observados em plagioclásio concentrando-se nos núcleos dos cristais; a clorita altera essencialmente a biotita.

O padrão de deformação nestas rochas se mostra de maneira análoga ao granitóide Taipas. Nos agregados de quartzo existe um predomínio de grãos mais grosseiros com deformação marcada por cristais mais intensamente tensionados, originando localmente recristalização com bordas sinuosas (de menor equilíbrio). Nas regiões de maior deformação o mosaico de quartzo desenvolve estrutura de faixas ou "ribbons", com grãos de contornos mais retilíneos de ângulo diedro $\sim 120^{\circ}$ (maior equilíbrio), orientadas paralelamente à distribuição alongada dos agregados de minerais máficos.

A sequência de cristalização magmática se mostra semelhante ao granitóide Taipas, tendo-se inicialmente a formação dos acessórios (apatita, minerais opacos e zircão) seguidos por titanita e allanita, e a seguir os minerais principais, inicialmente feldspato potássico fenocristalino e plagioclásio, depois a biotita, sucedidos na ordem por quartzo e feldspato potássico intersticial.

\subsubsection{Granitóide Taipas}

As rochas encontradas nas três bossas que constituem este maciço são bastante semelhante entre si. A rocha mostra textura porfirítica com megacristais de feldspato potássico, de até $30 \mathrm{~mm}$, tabulares (Foto 5.25). A composição modal predominante é granodiorítica, com variações para quartzo-monzodiorito, quartzo-monzonito e granito (Tabela 5.2, Figura 5.5). A matriz, média a grossa, inequigranular e hipidiomórfica, é constituída por plagioclásio ripiforme a equidimensional, quartzo equidimensional e escasso feldspato potássico intersticial. Preferencialmente, os minerais máficos ocorrem como agregados que se distribuem de maneira homogênea, vez por outra denotando uma foliação incipiente; os agregados estão constituídos por biotita acastanhada predominante, hornblenda verde-oliva, titanita euédrica, minerais opacos (subédricos a irregulares), apatita e rara allanita. Diferencia-se das fácies vizinhas do granito Cantareira pela abundância maior de fenocristais e a quase ausência de feldspato potássico na matriz (comparar a Foto 5.24 com a 5.25), além de apresentar honblenda como mineral máfico, ausente na fácies descrita do maciço Cantareira.

Os megacristais de feldspato potássico apresentam-se bastantes frescos, tabulares a equidimensionais, com contornos irregulares com discretas mirmequitas; mostram geminação Carlsbad e cruzada, mais restrita às bordas, e pertitas filamentosas. Como inclusões tem-se titanita euédrica e quartzo em gota a irregular, que se distribuem ao longo da borda, e subordinadamente alguns grãos de plagioclásio subédrico a irregular e agregados máficos. O feldspato potássico intersticial, de ocorrência bastante restrita, apresenta-se como pequenos cristais dispersos no quartzo ou próximos aos megacristais; é frequente o desenvolvimento de geminação em grade e pertitas alongadas. 
O plagioclásio, alongado a equidimensional, com até $6 \mathrm{~mm}$ de tamanho, mostra uma zonalidade fraca, com núcleos de contornos irregulares e bordas largas, mais albíticas. A geminação em periclínio é quase tão frequente como a da albita, ocorrendo ainda subordinadamente em alguns grãos a geminação combinada Carlsbad-albita. Por vezes é observada antipertita de contornos irregulares (e.g., lâmina TP 7-13). As inclusões, raras, são de pequenos grãos de quartzo (em gotas) e de biotita. Inclusões fluidas são abundantes.

O quartzo aparece em agregados, mostrando subgrãos anédricos, com no máximo $2,0 \mathrm{~mm}$, de contornos irregulares e extinção ondulante moderada a forte, mas diferente da do subgrão vizinho. Em muitos casos observa-se a recristalização do quartzo em grãos menores, mais ainda com contatos sinuosos tipificando falta de equilíbrio (e.g., lâmina TP 6-1). Contornos de equilíbrio só são observados localmente, em mosaicos construídos por grãos pequenos (0,1 mm ou menor) de contatos retilíneos (e.g., lâmina TP 6-6).

Nos agregados máficos predomina a biotita (pleocroismo marrom esverdeado a amarelo-bege claro), como lâminas de contornos irregulares e dimensões em torno de 1 a $2 \mathrm{~mm}$ (ou menores). Apresenta inclusões de titanita, apatita, minerais opacos, allanita e alguns diminutos cristais de zircão. Halos pleocróicos são encontrados em volta do zircão, da allanita e de titanita. O anfibólio, menos abundante, é subidiomórfico a xenomórfíco (até $1 \mathrm{~mm}$ ), com pleocroismo de verde grama azulado até bege amarelado claro. É de distribuição irregular e ausente em algumas lâminas (e.g., TP 6-6); mostra aparentemente passagem para biotita, (por reação magmática?; e.g., lâminas TP 6-5 e TP 6-12).

A titanita é frequente nestes agregados, como apatita e minerais opacos; ocorre como cristais euédricos a subédricos com dimensões de 1-3 mm, podendo aparecer ainda como inclusões em minerais félsicos da rocha. A allanita apresenta-se com frequência de apenas um ou dois cristais euédricos por lâmina, com dimensões de até $2 \mathrm{~mm}$, sempre em associação com titanita, opacos e apatita. $\mathrm{O}$ zircão apenas é observado como pequenas inclusões em biotita. O epidoto mostra contornos idiomórficos (e em parte geminados), sugerindo tratar-se de mineral magmático, ocorrendo em associação com outros minerais máficos (e.g., lâmina TP 6-5).

Como sinais de alteração tem-se o aparecimento de minúsculos cristais de sericita e epidoto em grãos de feldspatos; a alteração é mais frequente em plagioclásios, onde grãos relativamente frescos aparecem conjuntamente com outros bastante alterados. $\mathrm{Na}$ biotita a alteração, rara, é para clorita.

A deformação é expressa de maneira diferenciada nos diversos minerais da rocha. Nos feldspatos potássicos é responsável pela extinção irregular, chegando em alguns casos a desenvolver fraturas. Nos plagioclásios, além da extinção irregular e a formação de subgrãos, provoca atenuação na aparição das lamelas da geminação de albita e curvatura leve.No quartzo, a deformação desenvolve extinção ondulante e a geraÇão frequente de subgrãos.

Quando a deformação é mais intensa, nas proximidades das zonas de cisalhamento, a rocha toma outro aspecto, desenvolvendo localmente na matriz faixas de maior deformação caracterizadas por intensa recristalização do quartzo que envolve 
porfiroclastos de feldspatos e agregados alongados de minerais máficos, denotando textura granoblástica poligonal.

A partir das relações texturais observadas as primeiras fases minerais magmáticas a cristalizar foram apatita e zircão seguidas em ordem pelos minerais opacos, titanita e allanita, e provavelmente também a hornblenda. A seguir iniciou-se a cristalização dos fenocristais de feldspato potássico e do plagioclásio, seguidos da biotita, quartzo e o feldspato potássico intersticial.

\subsubsection{Granitóide Morro de Perús}

Apenas um único tipo de rocha granitóide foi encontrada nos matacões existentes no alto do Morro do Perus, em zona hoje urbanizada. A rocha apresenta estrutura orientada por deformação e recristalização parcial, com alguns cristais maiores de feldspato potássico. A matriz fina chega a desenvolver textura granoblástica poligonal englobando porfiroclastos subédricos a irregulares e fraturados de feldspato potássico e plagioclásio. A biotita e os minerais acessórios apresentam-se igualmente deformados, a primeira como agregados alongadas em associação com epidoto e titanita secundária, intensamente fraturada e distribuída sob forma de cordões. Os minerais opacos apresentam um distribuição semelhante, concentrando-se nas faixas de maior deformação.

Os escassos megacristais de feldspato potássico são tabulares, anédricos e de contornos sinuosos; mostram-se estirados, com extinção irregular e fenômenos de desmistura (presença de pertitas). O feldspato potássico intersticial, anédrico, é limpo, com geminação cruzada e sinais de desmistura.

Os cristais reliquiares de plagioclásio, alongados a equidimensionais, com até 2,5 $\mathrm{mm}$, subédricos a irregulares, mostram-se zonados, com extinção irregular e lamelas fracamente marcadas. A geminação do periclínio é frequente, sendo rara a do tipo albitaCarlsbad.

Os grãos anédricos de quartzo por vez apresentam dimensões variadas de até 1,3 $\mathrm{mm}$, com bordas sinuosas $\theta$ extinção ondulante moderada a forte. Mais frequentemente mostra-se como uma grancle massa quartzosa recristalizada, formando mosaicos com subgrãos de bordas retilíneas e ângulo diedro de $120^{\circ}$, evidenciando maior equilíbrio na recristalização.

Como mineral de alteração foi observada a sericita que se distribue nos plagioclásios, concentrada ao longo das lamelas de geminação.

Houve certa dificuldade em se estabelecer a sequência de cristalização devido ao grau de deformação da rocha, mas ela não deve diferir do esperado para granitóides com estruturas porfiríticas (ver acima, granitóides Taipas e Cantareira). Os minerais opacos, que se distribuem nas faixas de maior deformação, são fases tardias concentradas posteriormente à fase de deformação da rocha. 


\subsubsection{Granito Tico-Tico}

As rochas deste maciço foram coletadas em apenas uma localidade, na pedreira Pedralix, com acesso pela rodovia Anhanguera (ver mapa do Anexo 1). A rocha é de textura inequigranular a porfiritica, hipidiomórfica, com megacristais de feldspato potássico enquanto que na matriz, de granulação média, predominam o plagioclásio, como conjunto de vários grãos agrupados, e o quartzo, com algum feldspato potássico intersticial. As amostras estudadas mostram visivel diferenças no seu grau de deformação e consequente orientação e nos teores de feldspato potássico (Fotos 5.26 e 5.27). A composição modal varia de sienogranítica a monzogranítica e monzonítica (Tabela 5.2, Figura 5.5). Os glomérulos de minerais máficos estão constituídos por biotita e muscovita, geralmente predominando a última; são intersticiais aos outros minerais. A granada aparece ora associada a minerais máficos, ora inclusa em outros minerais.

Os megacristais de feldspato potássico são tabulares $(1-2 \mathrm{~cm})$, de contornos sinuosos, pertitícos (com pertitas "em chamas") e mostram aparição irregular de geminação cruzada. Em parte, aparecem orientados (Foto 5.27). As abundantes inclusões são principalmente de plagioclásios menores (com uma características borda albítica); as de quartzo se mostram irregulares e mais raras. O feldspato potássico na matriz, irregular, apresenta poucas inclusões.

O plagioclásio mostra contornos sinuosos. Apresentam inclusões frequentes de gotas de quartzo e rara turmalina schorlítica. A geminação de albita, predominante, é extremamente fina.

O quartzo aparece como mosaicos formados por recristalização mostrando subgrãos, com contato nítido geralmente imbricado.

A biotita apresenta-se com forte pleocroísmo (marrom avermelhado a amarelo claro) e frequente halos pleocróicos. A muscovita associa-se à biotita mas também é encontrada separadamente. A granada, equidimensional e subidiomórfica, ocorre ora associada a micas, ora como grãos separados; na lâmina TT 10-2 é observado o cristal de granada com aparente substituição (ou intercrescimento) por turmalina e muscovita. A turmalina aparece associada às micas ou como grãos esporádicos isolados.

O produto de alteração é a muscovita, que se desenvolve-se como pequenas palhetas sobre megacristais de feldspato potássico, mas atinge dimensões maiores como alteração nos plagioclásios. Clorita aparece como alteração em cristais de biotita.

A deformação é registrada nos cristais dobrados de biotita e plagioclásio, e nos subgrãos de quartzo, em parte recristalizado.

A ordem de cristalização no granito a duas micas inicia-se com os minerais acessórios (turmalina, granada, muscovita e biotita), em parte concomitantemente com o feldspato potássico megacristalino e plagioclásio, finalizando com quartzo e feldspato intersticial. 

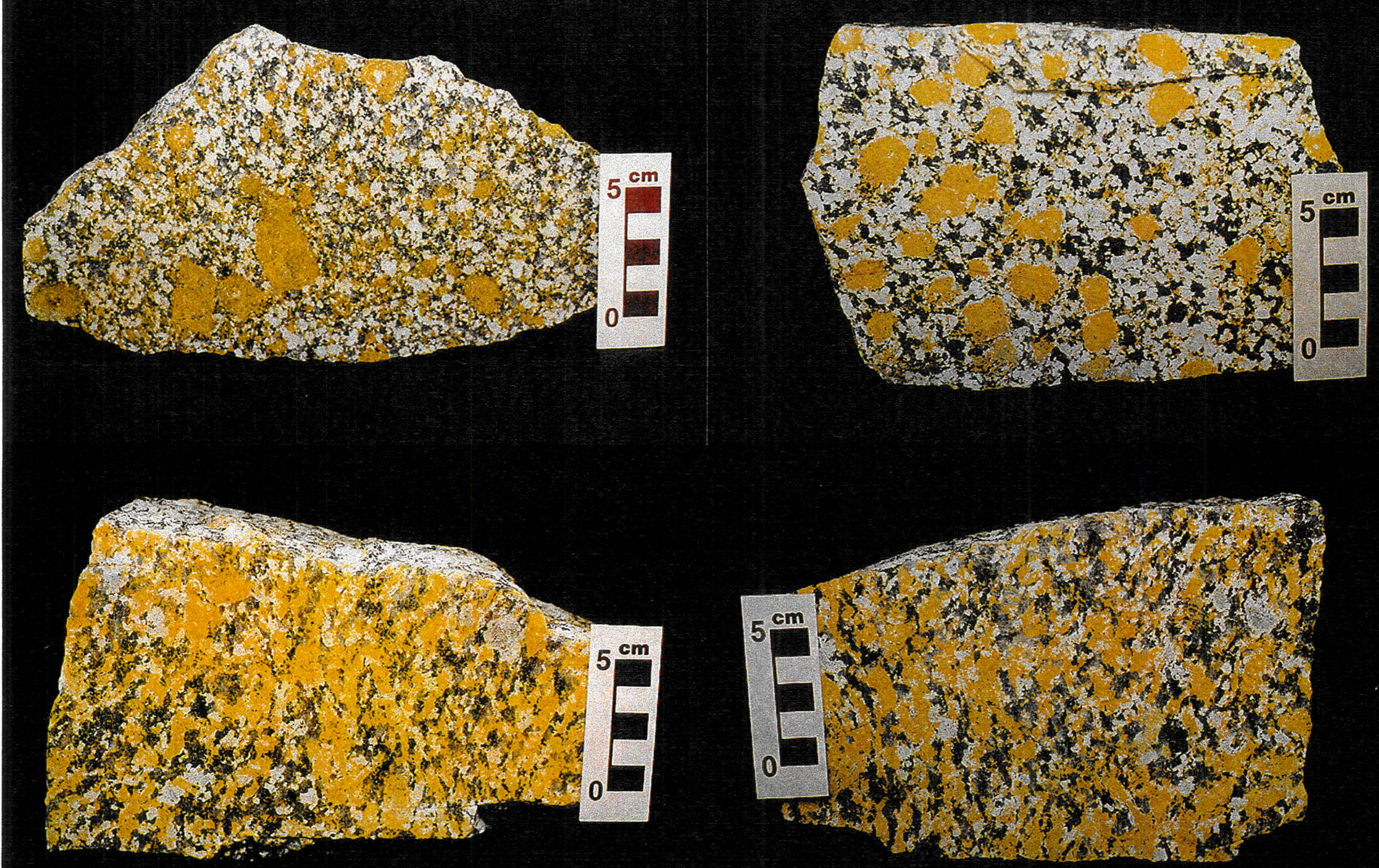


\begin{tabular}{l|l}
5.24 & 5.25 \\
\hline 5.26 & 5.27
\end{tabular}

Foto 5.24. Fatia do granito Cantareira, fácies porfirítica (amostra CA 8-12, pedreira Panorama).

Foto 5.25. Fatia do granito Taipas (amostra TP 6-12, pedreira Construcap). Observar as diferenças em relação ao granito Cantareira, em termos de fenocristais e feldspato potássico da matriz.

Foto 5.26. Granito Tico-Tico, amostra enriquecida em feldspato potássico (amostra TT 10-6, pedreira Pedralix).

Foto 5.27. Granito Tico-Tico, em parte com fenocristais de feldspato potássico orientados. (amostra TT 10-1, pedreira Pedralix). Comparar com fotografia anterior. 
Tabela 5.2. Dados modais de granitóides dos maciços Cantareira (CA), Taipas (TP) e Tico-Tico (TT).

\begin{tabular}{|c|c|c|c|c|c|c|c|c|c|c|c|c|c|c|c|}
\hline Amostra & Quartzo & $\begin{array}{l}\text { Feldspato } \\
\text { Potássico }\end{array}$ & Plagioclásio & Biotita & Hornblenda & Muscovita & Granada & Titanita & Alanita & Apatita & $\begin{array}{c}\text { Minerais } \\
\text { opacos }\end{array}$ & Epidoto & Clorita & Carbonato & $\begin{array}{l}\text { Félsicos/ } \\
\text { Máficos }\end{array}$ \\
\hline TP $5-2$ & 24,10 & 22,00 & 43,40 & 6,60 & 1,57 & 0 & 0 & 1,03 & 0 & 0,16 & 0,67 & 0,43 & 0 & 0,04 & $89,50 / 10,50$ \\
\hline TP $6-12$ & 22,00 & 25,50 & 42,30 & 6,10 & 1,55 & 0 & 0 & 0,88 & 0,26 & 0,29 & 0,74 & 0,33 & 0 & 0,05 & $89,80 / 10,20$ \\
\hline TP $6-15$ & 17,20 & 21,70 & 50,10 & 8,36 & 0 & 0 & 0 & 0,22 & 0 & 0,22 & 0,61 & 0,27 & 1,32 & 0 & $89,00 / 11,00$ \\
\hline TP $7-22$ & 23,60 & 18,40 & 44,10 & 9,00 & 0,44 & 0 & 0 & 2,20 & 0 & 0,58 & 1,24 & 0,43 & 0 & 0 & $86,10 / 13,90$ \\
\hline TP $7-24$ & 20,30 & 24,90 & 43,90 & 7,72 & 0,46 & 0 & 0 & 1,17 & 0,07 & 0,34 & 0,69 & 0,44 & 0 & 0 & $89,10 / 10,90$ \\
\hline $\operatorname{TP} 7-25$ & 20,40 & 21,50 & 45,40 & 8,15 & 0,41 & 0 & 0 & 1,47 & 0,36 & 0,48 & 1,22 & 0,61 & 0 & 0 & $87,30 / 12,70$ \\
\hline TP $7-26$ & 16,30 & 30,20 & 41,60 & 8,90 & 0,33 & 0 & 0 & 0,74 & 0,18 & 0,40 & 1,03 & 0,25 & 0 & 0 & $88,10 / 11,90$ \\
\hline CA 8 - 9 & 20,20 & 28,00 & 38,30 & 9,48 & 0 & 0 & 0 & 1,85 & 0,18 & 0,45 & 1,23 & 0,12 & 0,18 & 0 & $86,50 / 13,50$ \\
\hline CA $8-12$ & 19,50 & 38,20 & 36,50 & 4,08 & 0 & 0 & 0 & 0,73 & 0,15 & 0,26 & 0,44 & 0,14 & 0 & 0 & $94,20 / 5,80$ \\
\hline CA 8 - 22 & 21,90 & 33,60 & 38,10 & 4,52 & 0 & 0 & 0 & 0,69 & 0,19 & 0,19 & 0,60 & 0,21 & 0 & 0 & $93,60 / 6,40$ \\
\hline CA $8-13 a$ & 19,00 & 30,90 & 41,60 & 5,92 & 0 & 0 & 0 & 0,89 & 0,22 & 0,31 & 0,57 & 0,18 & 0 & 0 & $91,50 / 8,50$ \\
\hline CA $8-23$ & 20,10 & 33,20 & 37,30 & 6,54 & 0 & 0 & 0 & 0,98 & 0,25 & 0.25 & 0,73 & 0,19 & 0 & 0 & $90,60 / 9,40$ \\
\hline CA 8 - 33 & 15,60 & 33,90 & 40,90 & 7,14 & 0 & 0 & 0 & 1,01 & 0,20 & 0,28 & 0,77 & 0,19 & 0 & 0 & $90,40 / 9,60$ \\
\hline TT $10-1$ & 35,90 & 33,70 & 27,80 & 2,15 & 0 & 0,15 & 0,30 & 0 & 0 & 0 & 0 & 0 & 0 & 0 & $97,40 / 2,60$ \\
\hline TT $10-5$ & 31,20 & 41,80 & 19,30 & 5,80 & 0 & 1,00 & 0,90 & 0 & 0 & 0 & 0 & 0 & 0 & 0 & $92,30 / 7,70$ \\
\hline TT $10-6$ & 26,20 & 44,90 & 21,70 & 5,07 & 0 & 1,20 & 0,93 & 0 & 0 & 0 & 0 & 0 & 0 & 0 & $92,80 / 7,20$ \\
\hline TT $10-16$ & 32,40 & 44,20 & 18,70 & 3,57 & 0 & 0,36 & 0,78 & 0 & 0 & 0 & 0 & 0 & 0 & 0 & $95,30 / 4,70$ \\
\hline TT $10-7$ & 30,50 & 37,80 & 22,10 & 8,71 & 0 & 0,57 & 0,36 & 0 & 0 & 0 & 0 & 0 & 0 & 0 & $90,40 / 9,60$ \\
\hline
\end{tabular}




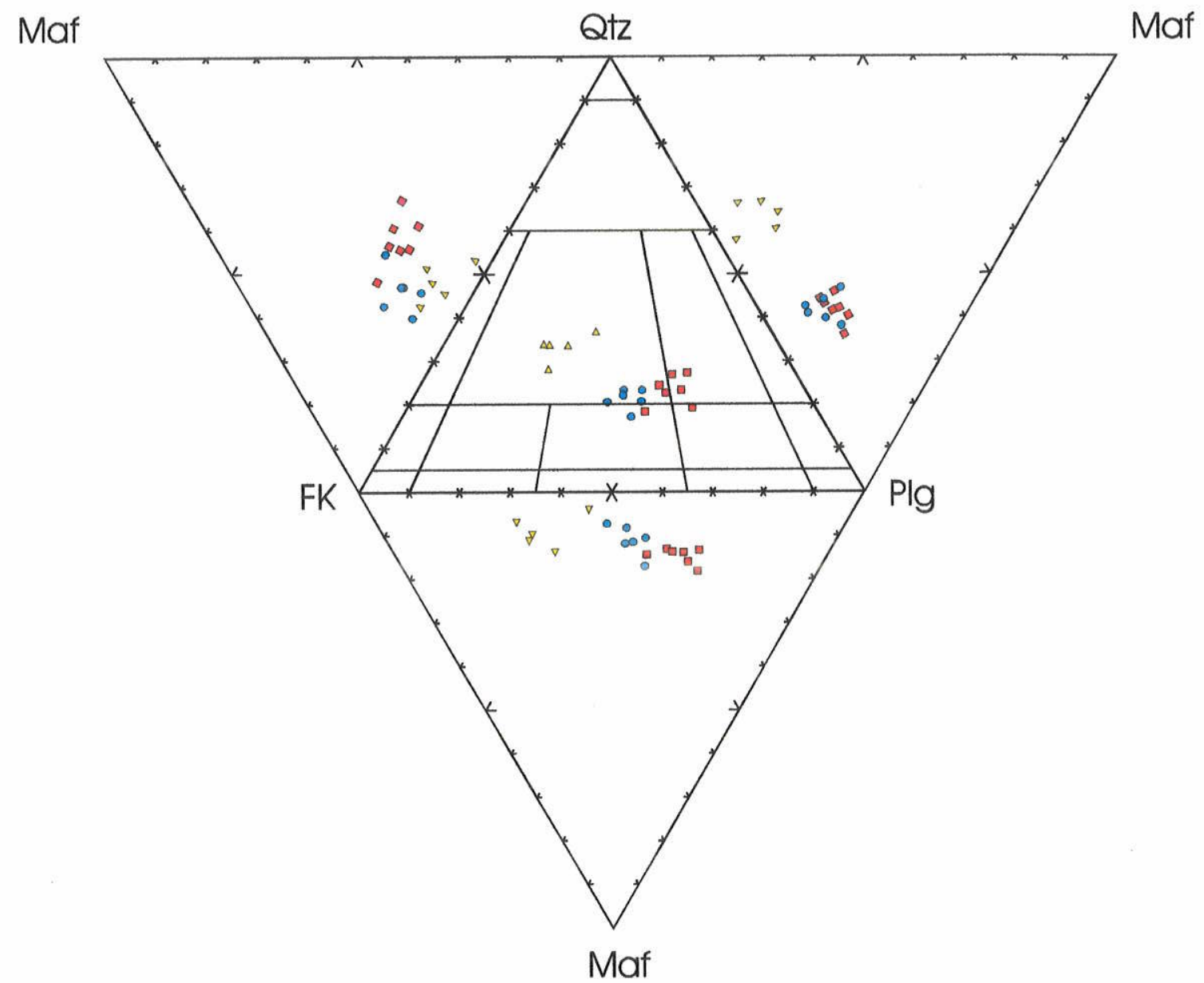

Figura 5.5. Diagrama modal Q-A-P-M para os granitóides dos corpos maiores: Cantareira (círculos, em azul), Taipas (quadrados, em vermelho) e Tico-Tico (triângulos, em amarelos). 


\section{CAPÍtULO 6}

\section{CONSIDERAÇÕES FINAIS}

1. A presente dissertação apresenta, no seu Capítulo 2, uma compilação sobre o "Contexto geotectônico regional", mostrando em sequência a aparicão dos mais importantes modelos geológico-geotectônicos gerais para a área de embasamento do SE brasileiro, com ênfase maior em São Paulo, devidamente ilustrados. Entre estes, contam-se principalmente o modelo geossinclinal de Ebert (1968), o geotectônico proposto por Almeida, Hasui e colaboradores (1966-1981) e o de deformação sequenciada em borda cratónica de Campos Neto, Basei, e colaboradores (1984-1991). Esta apresentação, sem ser completa e incluir todos os trabalhos relacionados ao tema, mostra claramente a progressão das idéias tanto em função da própria evolução do pensamento geológico (de "geossinclíneos" até a "tectônica de placas") como da realização de mapeamentos cada vez mais sistemáticos e detalhados.

2. Numa segunda parte, aparece no mesmo capítulo um resumo sobre a distribuição dos granitóides brasilianos e pré-brasilianos no estado de São Paulo, localizados indistintamente em todas as fatias ou "domínios" em que é possível dividir o embasamento da região. Estas fatias representam hoje terrenos alôctones, com deslocamentos relativos certamente muito significativos, sempre limitadas por importanates zonas de cisalhamento. A divisão corriqueira destes granitóides toma como referência a sua colocação em relação aos fatores tectônicos, aparecendo com isto as rochas consideradas pré-tectônicas, separadas dos maciços sin-, tardi- e pós-tectônicos, todos com representantes neste embasamento. As datações mais novas, baseadas na metodologia $\mathrm{U} / \mathrm{Pb}$, parecem identificar dois eventos brasilianos como muito importantes, um anterior e provavelmente "sin-tectônico", com idade em torno de $630 \mathrm{Ma}$, o outro posterior e "tardi-tectônico", com colocação por volta de 580 Ma.

3. No Capítulo 3 é apresentada uma compilação regional das folhas Guarulhos e Santana do Parnaiba, em escala original 1:50.000 e reproduzida em escala 1:100.000, que reune as informações espalhadas em várias trabalhos de pós-graduação (Carneiro, 1983; Bergmann, 1988; Dantas, 1990; Ferreira, 1991), mostrando principalmente a distribuição dos maciços granitóides mapeados na região (maciços Taipas, Tico-Tico, Mairiporã, Juquerí, Itaim e Morro do Perus, e partes dos maciços Itaqui e Cantareira, além de vários corpos de pequenas dimensões). Os turmalina granitos de Perus já foram objeto de estudos desde cedo, chamando a atenção principalmente pela sua mineralogia extremadamente diferenciada. Vários outros corpos menores aparecem em geral deformados e são considerados por alguns autores (e.g., Dantas, 1990) como "pré-brasilianos", mas podem igualmente representar fácies sintectônicas, apenas mais deformadas em função de colocação inicial no ciclo brasiliano, ou por estar alojadas perto de zonas de cisalhamento de maior dimensão (e.g., perto da falha de Jundiuvira, ao norte da folha: Mato Dentro, Vargem Grande, Fracisco Morato, e outros). São também indicados, no mapa de compilação, os vários eixos de dobras identificados pelos autores citados. 
4. O objetivo principal desta dissertação é o de estudar geologica e petrograficamente os turmalina granitos de Perus. Os resultados de um mapeamento de detalhe, em escala 1:5.000, são mostrados no Capitulo 4. Aparecem representadas as bossas mais expressivas de turmalina granitos, com exposições em geral muito boas, já que elas foram (ou são) objeto de exploração como pedreiras. As dimensões maiores não ultrapassam os $100 \times 200$ m. Nelas, observa-se complexa variedade faciológica, identificando-se como mais importantes as fácies bandada e a pegmatitica interna; a fácies homogênea é de distribuição muito restrita. Os corpos menores são encontrados, em geral, como diques e veios, que se extendem por poucos metros ou dezenas de metros, constituídos por turmalina granitos bandados e por pegmatitos (a fácies pegmatítica externa). Predominam, nas fácies homogênea e pegmatítica interna, os minerais feldspato potássico, plagioclásio (oligoclásio), quartzo e turmalina, com apatita e granada como fases acessórias, na fácies bandada o plagioclásio é o feldspato mais abundante. A turmalina predominante tem composição schorlítica, encontrando-se ainda turmalina bege-esverdeada e principalmente rósea como constituente significativo da fácies pegmatítica interna. Os tamanhos dos grãos variam, desde granulação média-grossa (fácies bandada e homogênea) até dimensões centimétricas ou de decímetros (feldspatos e turmalinas nas fácies pegmatíticas). A mineralogia secundária, que se apresenta como agregados formados por substituição tardia na fácies pegmatítica interna e em fraturas, é muito variada, citando-se micas claras e arroxeadas (muscovita, micas de Li), opala, minerais de U, etc. (e.g., Teuppenhayn, 1994; Atencio, 1991).

5. Todos os corpos de turmalina granitos estão localizados principalmente ao longo de um sistema de cisalhamento $N E$, mostrando a mesma direção que o sistema proeminente também em escala regional. É visível ainda um sistema de cisalhamento de direção $N W$, como o anterior marcado principalmente por faixas cisalhadas que cortam os granitos (tanto os com turmalina como os maciços maiores Cantareira e Taipas); de aparição mais localizada (pedreira no maciço Cantareira) é um sistema $E-W$ de cisalhamento. A quantidade total de corpos deve ser de várias dezenas, visíveis principalmente como manchas de alteração nos solos; alguns deles extendem-se até as vizinhanças de Mairiporã, já fora da região do mapeamento de detalhe, ao longo do sistema NE de cisalhamento.

6. Estudos petrográficos, em escala meso- e microscópica, mostram que a fácies bandada é constituida por unidades ou bandas, cada uma com níveis diferentes, que mostram variações tanto modais (mineralogia) como texturais (tamanhos de grãos). As bandas apresentam-se com espessura variada, cada uma em geral entre 3 a $7 \mathrm{~cm}$, e aparecem repetidas até várias dezenas de vezes, com percurso visível por vários metros, em geral com deformação marcada (padrão de "redobramento"). Cada banda mostra um nivel inferior, em geral com quartzo como mineral predominante (e que, na amostra de mão, aparece com cor geral cinzenta), um nivel intermediário predominante ( $2 / 3 \mathrm{da}$ banda), com feldspatos como fases importantes (cor geral esbranquiçada), e um nível superior de cor preta, enriquecido em turmalina schorlítica prismática. Estas variações, com visível aumento nas dimensões dos grãos, representa o "padrão granocrescente normal" de bandamento; são encontrados ainda um padrão normal equigranular e, aparentemente, o normal granodecrescente. $O$ padrão inverso (com turmalina mais abundante na base) é observado apenas como resultado de inversão geométrica por efeitos do dobramento. A turmalina, embora enriquecida no nível superior, aparece também, em menores proporções, no nível intermediário; está quase ausente no nível inferior. Com alguma 
fequência são observadas bandas com limites difusos, sendo então também mais difícil o reconhecimento dos níveis citados.

7. A composição petrográfica da fácies bandada é, em conjunto, a de granodiorito, enquanto que a fácies homogênea apresenta composição sieno- a monzogranítica, como mostrado por contagens modais em três bandas e três amostras de granito homogêneo (todos em lâminas petrográficas). Estas variações, não esperadas, são de difícil explicação.

8. Os minerais que compõem as bandas não estão deformados, e a sua origem não tem causas tectônicas. As bandas, em consequência, são de origem sin-magmática, ou seja, desenvolveram-se provavelmente em pequenas câmeras fechadas, com deformação durante o evento de cristalização e de geração do bandamento. Sem entrar nos complexos detalhes ligados ao mecanismo magmático que gera bandamento, deve ser lembrado que as hipóteses a serem utilizadas não podem fugir das explicações oferecidas para o caso dos clássicos maciços estratiformes, de composição em geral basáltica. Chama a atenção, em particular, o bandamento muito regular e repetitivo (e.g., "inch scale layering") descrito nestes maciços, no qual cada banda mostra-se variações tanto modais como texturais, com estrutura interna portanto similar em geometria ao aqui descrito nos turmalina granitos. Argumenta-se na literatura especializada (e.g., Irvine, 1980, e bibliografia ali citada) que as bandas com essas características não se geram apenas por sedimentação controlada por gravidade, mas que deve ser utilizado, de preferência, o mecanismo conhecido como difusão dupla convectiva ("double convective diffusion"). Neste, formam-se na câmera magmática bandas líquidas, a inferior sempre com densidade maior que a superior, esta por sua vez levemente mais fria que a inferior. Evidentemente, a banda mantêm equilíbrio térmico e químico no seu interior, através da aparição de diminutas células de convecção. Cada banda está isolada da inferior e da suprajacente, exceto por alguma difusão ao estado líquido (química, térmica), aparentemente pouco importante. A seguir, cada banda inicia a sua cristalização, quando é atingido o "liquidus", com deposição inicial das fases precoces na parte inferior e gradativa acumulação de cristais, da base para o topo, e participação concomitante nesse esquema de cristalização do líquido "intercumulus", acumulado entre os grãos já depositados (ver esquema em Irvine, 1980). As variações modais encontradas nas bandas destes turmalina granitos indicam que a cristalização precoce forma principalmente quartzo e feldspatos (nível inferior), com mudança, a seguir, para cristalização principal de feldspatos com menos quartzo (nível intermediário) e cristalização final do nível superior, enriquecido em voláteis $(\mathrm{B}, \mathrm{H} 2 \mathrm{O})$ e $\mathrm{FeO}-\mathrm{MgO}$. Uma análise mais aprofundada deste modelo de cristalização requer uma avaliação com ajuda de dados químicos (minerais e rocha), com utilização também dos dados experimentais sobre a cristalização de granitóides enriquecidos em $B, F$, etc.

9. As relações entre os turmalina granitos de Perus e os outros maciços graníticos da região, particularmente com os maciços Cantareira e Taipas, não são evidentes. Na literatura já foram divulgados modelos bastante sofisticados, com utilizaçào de dados de geoquímica de rochas e tipologia do zircão, que mostram modelos evolutivos que levam aos magmas muito diferenciados dos turmalina granitos, partindo de magmas mais ou menos cálcio-alcalinos (Teuppenhayn, 1994; Wernick \& Teuppenhayn, 1996). Mesmo assim, pairam algumas dúvidas, indicadas a seguir: 
cisalhamento, que os separam (ver Anexos 1 e 2), indica claramente que eles deviam estar ainda mais afastados à época de cristalização e colocação.

b). Os turmalina granitos cristalizaram, provavelmente, mais perto da superficie que os maciços maiores, uma afirmação também feita por outros autores (e.g., Teuppenhayn, 1994). O maciço Cantareira forma, por outro lado, um alto topográfico proeminente na região, os seus afloramentos colocados em níveis muito superiores aos dos turmalina granitos (ver Anexos 1 e 2) e não é possível realizar uma reconstrução simples que permita localizar os turmalina granitos como cúpulas do maciço Cantareira. Se os turmalina granitos são de fato apêndices ou cúpulas de granitos menos evoluídos., então eles não parecem aflorar na região.

c). Não está resolvida a questão das idades dos respectivos granitóides (ver Tabela 2.2): para os turmalina granitos postulam-se as idades discrepantes de $650 \pm 20 \mathrm{Ma}(\mathrm{K} / \mathrm{Ar}$, em micas de $\mathrm{Li}$ ) e U/Pb de $566 \pm 6 \mathrm{Ma}$, e para as fácies porfiríticas do maciço Cantareira idades U/Pb de $669 \pm 8 \mathrm{Ma} \mathrm{e} 630 \pm 8 \mathrm{Ma}$ (Tassinari, 1988; Töpfner, 1996); Teuppenhayn (1994) determina uma terceira idade $\mathrm{U} / \mathrm{Pb}$ de $572 \pm 9 \mathrm{Ma}$. Os granitos diferenciados só poderiam ser relacionados com o magmatismo Cantareira se a sua idade fosse: 1) de 560$570 \mathrm{Ma}$, que coincidiria com a idade de 572 Ma de Teuppenhayn (1994) ou, 2), alternativamente, de 630-660 Ma, e então a idade do Cantareira deveria ser $>600 \mathrm{Ma}$. Por motivos discutidos no item 2.3.3, sobre idades dos granitos, prefere-se aqui um modelo que supõe a idade de $630 \mathrm{Ma}$ para as fácies mais importantes do maciço Cantareira; sendo assim, a idade dos turmalina granitos de Perus deveria ser similar, mas não existe confirmação para esta suposição, já que as idades $\mathrm{K} / \mathrm{Ar}$ previamente registradas de $650 \mathrm{Ma}$ podem ser questionadas. 


\section{REFERÊNCIAS BIBLIOGRÁFICAS}

Almeida F.F.M. 1964. Fundamentos geológicos do relevo paulista. Bol. Inst. Geográfico Geológico, 41, 167-263.

Almeida F.F.M. 1966. Origem e evolução da Plataforma Brasileira. In: II Semana de Debates Geológicos, Porto Alegre, Centro Académico de Estudos Geológicos da UFRGS, p.45-89 (citado em Schobbenhaus et al., 1984, p.196).

Almeida F.F.M. 1967. Origem e evolução da Plataforma Brasileira. Bol. Div. Geol. Mineralogia, Rio de Janeiro, 241, 36 p.

Almeida F.F.M. 1969. Diferenciação tectônica da Plataforma Brasileira. In: Congr. Brasil. Geologia, 23, Salvador, BA, SBG, Anais, 29-46.

Almeida F.F.M. 1971. Geochronological division of the Precambrian of South America. Rev. Brasil. Geociências 1, 13-21.

Almeida F.F.M. 1977. O craton de São Francisco. Rev. Brasil. Geociências, São Paulo, 7, 349-364.

Almeida F.F.M., Amaral G., Cordani U.G., Kawashita K. 1973. The Precambrian evolution of the South American cratonic margin south of the Amazon river. In: Nairn A.E.M. \& Stehli F.G. (eds.) The Ocean Basins and Margins. Vol. 1, Plenum Press, Nova Iorque, 411-446.

Almeida F.F.M., Hasui Y., Brito Neves B.B. de. 1976. The Upper Precambrian of South America. Bol. IG, Instituto de Geociências, USP, São Paulo, 7, 45-80.

Almeida F.F.M. de, Hasui Y., Brito Neves B.B. de, Fuck R.A. 1981. Brazilian structural provinces: an introduction. Earth-Science Reviews, 17, 1-29.

Almeida F.F.M. et al. 1978. Tectonic map of South America 1:5,000,00. Explanatory Note. Brasilia, DNPM/CGMW/Unesco, 23 p.

Artur A.C. \& Wernick E. 1986. Interpretação geotectônica de alguns aspectos do embasamento cristalino do Estado de São Paulo e áreas adjacentes do Estado de Minas Gerais. In: Congr. Brasil. Geologia, 34, Goiânia, GO, SBG, Anais, vol. 3, 1285-1295.

Artur A.C., Ebert H.D., Wernick E. 1991a. Magmatismo e tectônica no Complexo Socorro (SP/MG). In: Simp. Geologia Sudeste, 2, São Paulo, 1991, Atas, São Paulo, SBG/NSP-RJ, 105-112. 
Artur A.C., Ebert H.D., Angeli N., Rueda J.R.J., Maniakas S. 1991b. Mapeamento Geológico em 1:50.000 da Quadricula Extrema. Local, convênio Pró-Minerio/IGCEUNESP, vol 1, 152 p. (Relatório final).

Artur A.C., Wernick E., Hörmann P.K., Weber-Diefenbach K. 1993. Associação plutônica do Complexo granitóide de Socorro (Estado de São Paulo e Minas Gerais, SE Brasil). Rev. Brasil. Geociências, 23, 3, 265-273.

Atêncio, D. (1988) Chenikovite, a new name for $\left(\mathrm{H}_{3} \mathrm{O}\right)_{2}\left(\mathrm{UO}_{2}\right)_{2}\left(\mathrm{PO}_{4}\right)_{2} \cdot 6 \mathrm{H}_{2} \mathrm{O}$ superseding "hydrogen autunite". Mineralogy Record, 19: 249-252.

Atêncio, D. (1991) Fucarlita e outros minerais Uraníferos secundários de Perús, São Paulo. São Paulo. (Tese de Doutoramento), Instituto de Geociências, USP. 147 p.

Atêncio, D., Hypólito, R. (1994). Fosfatos e silicatos secundários de urânio de Perús, São Paulo. Revista Brasileira de Geociências, 24(1):43-51

Aubouin J. 1965. Geosynclines. Elsevier, Amsterdam, 335 p.

Basei M.A.S., Siga Jr O., Sato K., Sproesser W.M. (1995) A metodologia urânio-chumbo na Universidade de São Paulo. Princípios metodológicos, aplicações e resultados obtidos. Anais Acad. Brasil. Ciências, 67, 221-237.

Bergmann M. 1988. Caracterização estratigráfica e estrutural da sequência vulcanosedimentar do grupo São Roque na região de Pirapora do Bom Jesus, Estado de São Paulo. (Dissertação de Mestrado), Instituto de Geociências, USP, São Paulo, 155 p.

Campos Neto M.C. 1985. Evolução do pré-Cambriano paulista e regiões adjacentes. In: Simp. Reg. Geologia, SBG, Núcleo de São Paulo, São Paulo, Atas, vol. 2, 561-571.

Campos Neto M.C. 1991. A porção ocidental da Faixa Alto Rio Grande - ensaio de evolução tectônica. (Tese de Doutoramento), Instituto de Geociêncas, USP, São Paulo, $210 \mathrm{p}$.

Campos Neto M.C. \& Basei M.A.S. 1983. Evolução estrutural brasiliana do nordeste de São Paulo: dobramentos superpostos e esboço estratigráfico e tectônico. In: Simp. Reg. Geologia 4, SBG, Núcleo SP, São Paulo, Atas, 61-78.

Campos Neto, M.C., Basei M.A.S., Alves F.R., Vasconcelos A.C.B.C. 1984. A Nappe de cavalgamento Socorro (SP-MG). In: Congr. Brasil. Geologia, 33, Rio de Janeiro, RJ, SBG, Anais, 4, 1809-1822.

Campos Neto M.C., Figueiredo M.C.H., Perrota M.M., Peloggia A.U.G. 1990. A porção ocidental da Faixa Alto Rio Grande (SP-MG). In: Congr. Brasil. Geologia, 36, Natal, RN, SBG, Anais, 6, 2615-2630. 
Carneiro C.D.R. 1983. Análise estrutural do Grupo São Roque na faixa entre o Pico do jaraguá e a Serra dos Cristais, S.P. (Tese de Doutoramento), Instituto de Geociências, USP, São Paulo, 155 p.

Cordani U.G. \& Bittencourt J. 1967. Determinações de idades potássio-argônio em rochas do Grupo Açunguí. In: Congr. Brasil. Geologia, 25, São Paulo, SP, SBG, Anais, 218-233.

Cordani U.G. \& Kawashita K. 1971. Estudos geocronológicos pelo método $\mathrm{Rb} / \mathrm{Sr}$ de rochas graníticas intrusivas no Grupo Açunguí. In: Congr. Brasil.Geologia, São Paulo, SP, SBG, Anais, vol. 1, 105-110.

Cordani U.G. \& Teixeira W. 1979. Comentários sobre as determinações geocronológicas existentes para as regiões das folhas Rio de Janeiro e Iguape. In: Schobbenhaus Filho C. (coord.): Carta Geológica do Brasil ao milionésimo. Texto explicativo das Folhas Rio de Janeiro (SF-23), Vitória (SF-24) e Iguape (SG-23). MME-DNPM, Brasília, 175-207.

Cordani U.G., Gomes C. B., Girardi V.A. 1963. Rochas calcio-silicáticas da região de Perus, S.P. Anais Acad. Brasil. Ciências, 35, 361-372.

Coutinho J. M. V. (1980) Carta geológica da região metropolitana da Grande São Paulo, 1:100.000. EMPLASA, São Paulo.

Dantas A.S.L. 1990. Geologia da Faixa São Roque e intrusivas associadas na região entre São Paulo e Mairiporã, norte de São Paulo, SP. (Dissertação de Mestrado), Instituto de Geociências, USP, São Paulo, 217 p.

Ebert H. 1968. Ocorrências da fácies granulítica no sul de Minas Gerais e em áreas adjacentes, em dependencia da estrutura orogênica: hipóteses sobre sua origem. Anais Acad. Brasil. Ciências, 40(suplemento): 215-229.

Ebert H.D., Chemale Jr. F., Babinski M., Artur A.C., Van Schmus W.R. 1996. Tectonic setting and $\mathrm{U} / \mathrm{Pb}$ zircon dating of the plutonic Socorro Complex in the transpressive Rio Paraíba do Sul shear zone belt, SE Brazil. Tectonics, 15, 688-699.

Ferreira C.J. 1991. Geologia, petrografia e tipologia de zircões da suite intrusiva Itaqui, Barueri, S.P. (Dissertação de Mestrado), Instituto de Geociências e Ciências Exatas, UNESP, Rio Claro, $253 \mathrm{p}$.

Ferreira C.J. 1997. Geoquímica e análise da deformação do Complexo Itaqui, SP: evolução de granitos cálcio-alcalinos poli-intrusivos. (Tese de Doutoramento), Instituto de Geociências e Ciências Exatas, UNESP, Rio Claro, 272 p.

Haddad R.C. 1995. O batólito granitóide Pinhal-Ipuiúna (SP-MG): um exemplo do magmatismo cálcio-alcalino potássico neoproterozóico no sudeste brasileiro. (Tese de Doutoramento), Instituto de Geociências, USP, São Paulo, 269 p.

Hasui Y. 1963. Sobre os granitos turmaliníferos de Perus, SP. Bol. Soc. Brasil. Geologia, $12,87-108$. 
Hasui Y. \& Hama M. 1972. Geocronologia do Grupo São Roque pelo método do potássioargônio. Rev. Brasil. Geociências, 2,18-24.

Hasui Y., Almeida F.F. de, Brito Neves B.B. 1978a. As estruturas brasilianas. In: Congr. Brasil. Geologia, 30, Recife, PE, SBG, Anais, 6, 2423-2437.

Hasui Y., Carneiro C.D.R., Bistrichi C.A. 1978b. Os granitos e granitóides da região de dobramentos sudeste dos estados de São Paulo e Paraná. In: Congr. Brasil. Geologia, 30, Recife, PE, SBG, Anais, 6, 2594-2608.

Hasui Y., Carneiro C.D.R., Coimbra A.M. 1975. The Ribeira Folded Belt. Rev. Brasil. Geociências, São Paulo, 5, 257-266.

Hasui Y, Mioto J. A. 1992. Geologia estrutural aplicada. Assoc. Brasil. Geologia. Eng., São Paulo, 257 p.

Hasui Y., Ponçano W. L., Bistrichi C. A., Stein D. P., Galvão C. A. C. F., Gimenez A. F., Almeida M. A., Pires Neto A. G., Melo M. S., Santos M. C. S. R. 1978a. Geologia da Região Administrativa 3 (Vale do Paraiba) e parte da Região Administrativa 2 (litoral) do Estado de São Paulo, São Paulo, IPT, (IPT, Monografia 1), 78 p.

Janasi V.A. 1992. Rochas sieníticas e mangerítico-charnoquíticas neoproterozóicas da região entre Caldas e Campestre (MG): aspectos petrológicos. (Tese de Doutoramento), Instituto de Geociências, USP, São Paulo, 289 p.

Janasi V.A. \& Ulbrich H. H. G. J. 1991. Late Proterozoic granitoid magmatism in the state of São Paulo, southeastern Brazil. Precambrian Research, 51, 351-374.

Janasi V.A. \& Ulbrich H.H.G.J. 1992. Inventário bibliográfico de granitos do Estado de São Paulo. Boletim IG-USP, Publicação Especial No 11, 253 p.

Juliani C. 1993. Geologia, petrogênese e aspectos metalogenéticos dos grupos Serra do Itaberaba e São Roque na região das serras do Itaberaba e da Pedra Branca, NE da cidade de São Paulo. (Tese de Doutorado), Instituto de Geociências, USP, São Paulo, 2 vols., 803 p.

Juliani C. \& Beljavskis P. 1995. Revisão da liotestratigrafia da Faixa São Roque/Serra do Itaberaba (SP). Rev. Instituto Geológico São Paulo, 16, 33-58.

Juliani C., Beljavskis P., Schorscher H.D. 1986. Petrogênese do vulcanismo e aspectos metalogenéticos associados: Grupo Serra do Itaberaba na região de São Roque. In Congr. Brasil. Geologia, 34, Goiânia, GO, SBG, Anais, 2, 730-743.

Juliani C., Martin M.A.B., Clarimundo S.J. 1997. Os metarcóseos do Morro do Polvilho: implicações para oa geocronologia e para a evolução crustal dos grupos Serra do Itaberaba e São Roque. Anais Acad.brasil.Ciências (no prelo).

Kay M. 1951. North American geosynclines. Geolog. Soc.America Memoir 48, 143 p. 
Krumbein W.C. \& Sloss L.L. 1951. Stratigraphy and Sedimentation. 2a. ed., Freeman, São Francisco, $660 \mathrm{p}$.

Lipman P.W. \& Mullineaux D.R. (eds.) 1981. The 1980 eruptions of Mount St. Helens, Washington. U.S. Geological Survey Prof. Paper 1250, 1-844.

Loczy L. de \& Ladeira E. 1980. Geologia Estrutural e Introdução à Geotectônica. Blücher$\mathrm{CNPq}$, São Paulo, $528 \mathrm{p}$.

Moraes Rego L.F. 1930a. Geomorphologia do Estado de São Paulo. Boletim do Serviço Geológico e Mineralógico, 46, 71-76.

Moraes Rego L.F. 1930b. Golpe de vista sobre os recursos minerais de São Paulo. Boletim de Agricultura, Secretaria da Agricultura, Industria e Comercio do Estado de São Paulo, (série 31), 1/2, 885-925

Moraes Rego L.F. 1933. Contribuição do estudo das formações pré-devoniadas de São Paulo. Boletim do Instituto Astronômico e Geográfico, 43 p.

Peloggia A. U. G. 1990. A Faixa Alto Rio Grande na região de Amparo, SP. (Dissertação de Mestrado), Instituto de Geociências da USP, São Paulo, 124 p.

Penalva F. \& Hasui Y. 1970. A intrusão granítica dos Morros Grande e Tico-Tico, município de Caieiras, SP, Anais Acad. Brasil. de Ciências, 42, 725-730.

Perrotta M.M. 1990. A Faixa Alto Rio Grande na região à sul de São Gonçalo de Sapucai, MG. (Dissertação de Mestrado), Instituto de Geociências, USP, São Paulo, 158 p.

Ponçano W. L., Carneiro C. D. R., Bistrichi C. A., Almeida F. F. M. de, Pradini F. L. (1981). Mapa geomorfológico do Estado de São Paulo, escala 1:500.000. São Paulo, IPT, 1. Nota explicativa. (Publicação IPT, 1183).

Schobbenhaus C., Almeida Campos D. de, Derze G.R., Asmus H.E. 1984. Geologia do Brasil. DNPM, Dep. Nacional Recursos Minerais, Brasília, 501 p.

Stille H. 1958. Die assyntische Tektonik im geologischen Erdbild. Beiheft zum Geologischen Jahrbuch, Hannover, 22, 255 p.

Ramsay J.G., Huber M.J. 1987. The techniques of modern structural geology (2 volumes). Academic Press, Londres, 700p.

Tassinari C.C.G. 1988. As idades das rochas e dos eventos metamórficos da porção sudeste do Estado de São Paulo e sua evolução crustal. (Tese de Doutoramento), Instituto de Geociências, USP, 236 p.

Tassinari C.C.G., Kawashita K., Kikuchi R.K.P. de. 1985. Estudo geocronológico nos metaconglomerados do Grupo são Roque, no Estado de São Paulo. In: Simp. Reg. Geologia, 5, São Paulo, SBG Núcleo de SP, Atas, 1, 201-208. 
Teuppenhayn J.P. 1994. Der spätpräkambrische Granit-Pegmatit-Komplex bei Perus und umliegende Granitoidkörper im Bundesstaat São Paulo/SE Brasilien: geologische, petrographische, geochemische und mineralchemische Untersuchungen unter zusätzlicher Beachtung akzessorischer Zirkone. Münchner Geologische Hefte, 14 (Tese de Doutoramento), Universidade de Munique, $302+58 \mathrm{p}$.

Töpfner C. 1996. Brasiliano-Granitoide in den Budesstaaten São Paulo und Minas Gerais, Brasilien - eine vergleichende Studie. Münchner Geologische Hefte, A-17, Reihe A, Allgemeine Geologie (Tese de Doutoramento), Universidade de Munique, $258 \mathrm{p}$.

Trompette R. 1994. Geology of Western Gondwana. Balkema, Rotterdam, 350 p.

Ulbrich H. G. H. J. 1984. A petrografia, a estrutura e o quimismo de nefelina sienitos do maciço alcalino de Poços de Caldas, MG-SP. (Tese de Livre-docência), Instituto de Geociências, USP, São Paulo, 395 p.

Van Schmus W.R., Tassinari C.C.G., Cordani U.G. 1986. Estudos geocronológicos da parte inferior do Grupo São Roque. In: Congr. Brasil. Geologia, 34, Goiânia, GO, SBG, 3, 1399-1405.

Vasconcellos A.C.B.C. 1988. O Grupo Andrêlandia na região à norte de Ouro Fino, MG. (Dissertação de Mestrado), Instituto de Geociências, USP, São Paulo, 199 p.

Vlach S.R.F. 1993. Geologia e petrologia dos granitóides de Morungaba, SP. (Tese de Doutoramento), Instituto de Geociências, USP, São Paulo, 414 p.

Wernick E. 1979. O magmatismo granitóide das Regiões de Dobramento Nordeste e Sudeste do Brasil. Rev. Brasil. Geociências 9, 122-139.

Wernick E. 1984. Caracterização genética de alguns granitóides brasilianos dos Estados de São Paulo e Minas Gerais e implicações geotectônicas preliminares. In: Congr. Brasil. Geologia, 33, Rio de Janeiro, RJ, SBG, Anais, 6, 2902-2918.

Wernick E. 1990. Zoneamento magmático regional de granitóides brasilianos no sudeste/sul do Brasil: implicações geotectônicas. In: Congr. Brasil. Geologia, 36, Natal, RN, SBG, Anais, 4, 1668-1683.

Wernick E., Weber-Diefenbach K., Correia L.A., Cerqueira C. 1985. Os granitos Mairiporã, Cantareira e Perus, arredores de São Paulo: dados químicos, tipologia de zircão e uma interpretação preliminar. In: Simp. Reg. Geologia, 5, São Paulo, 1985. Atas São Paulo, SBG/SP, 1, 3-18.

Wernick E. \& Galembeck T.M.B. 1985. Contribuição à caracterização de granitóides do Estado de São Paulo através do mineral acessório zirconita. In: Simp. Reg. Geologia, 5, São Paulo, SP, Núcleo SBG, 1, 119-132.

Wernick E.\& Galembck T.M.B. 1986. Caracterização do plutonismo granitóide do ciclo Brasiliano no Estado de São Paulo através do método da tipologia de zircão. In: Cong. Brasil. Geologia, 34, Goiânia, 1986. Anais Goiânia, SBG, 6, 1369-1382. 
Wernick E \& Penalva F. 1978. Contribuição ao conhecimento das rochas granitóides do S do Brasil. Rev. Brasil. Geociências 8, 113-133.

Wernick E. \& Penalva F. 1980. Contribuição à geologia do Grupo Pinhal (SP e MG). Rev. Brasil. Geociências 10, 43-62.

Wernick E., Artur A.C., Ferreira C.J. 1995. Evolução magmática em complexos granitóides associados à zonas de cisalhamento no Estado de São Paulo, Brasil. Geociências, São Paulo 14, 199-216.

Wernick E., Hasui Y., Brito Neves B.B. de. 1978. As regiões de dobramentos nordeste e sudeste. In: Congr. Brasil.Geologia, 30, Recife, PE, SBG, 6, 2493-2507. 


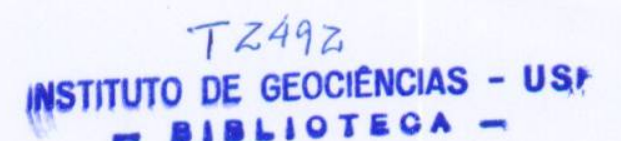

MAPA GEOLŌGICO REGIONAL

FOLHAS SANTANA DO PARNAIBA

E GUARULHOS

Anexo 1

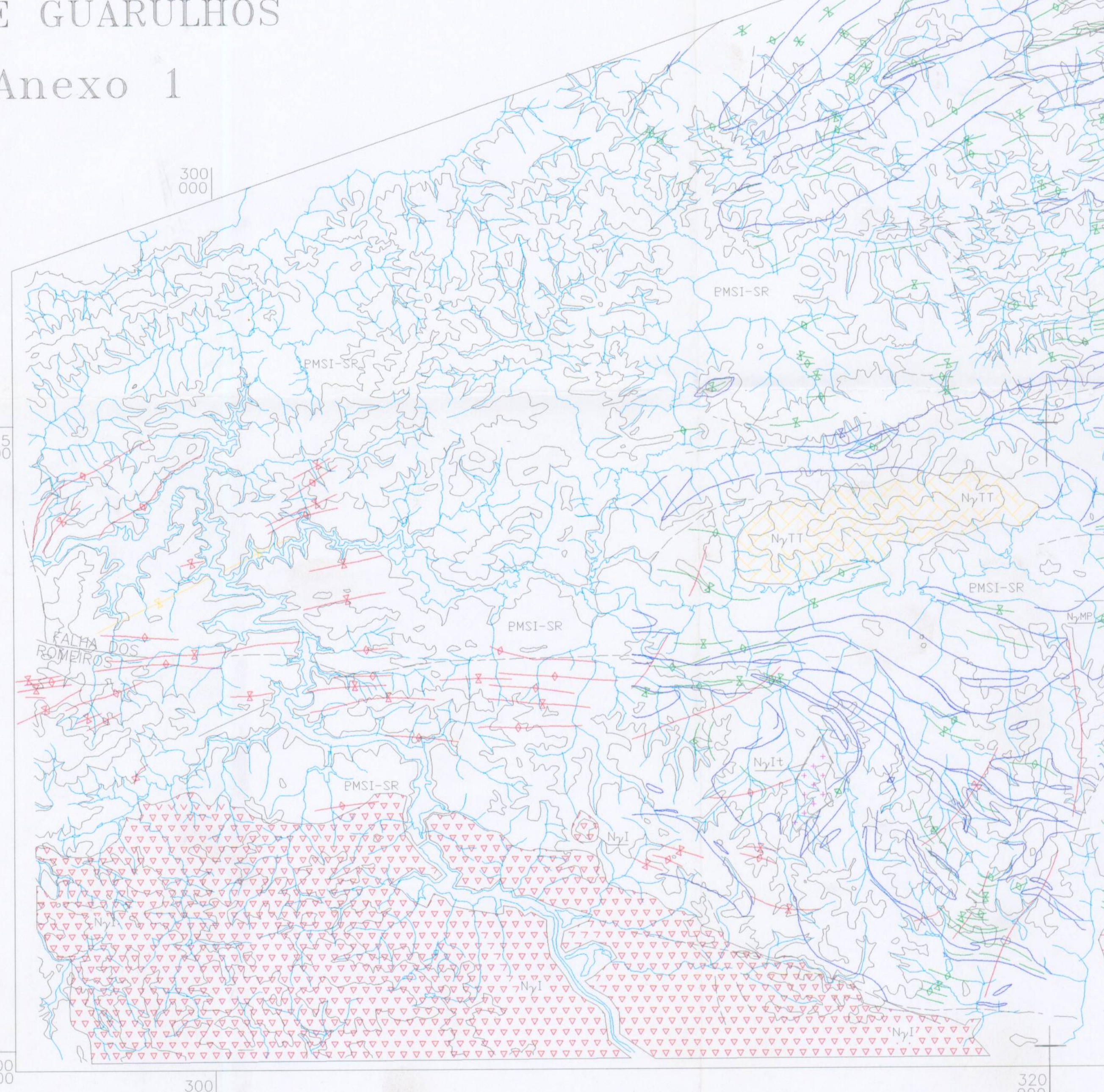

convenģaes gedógitas

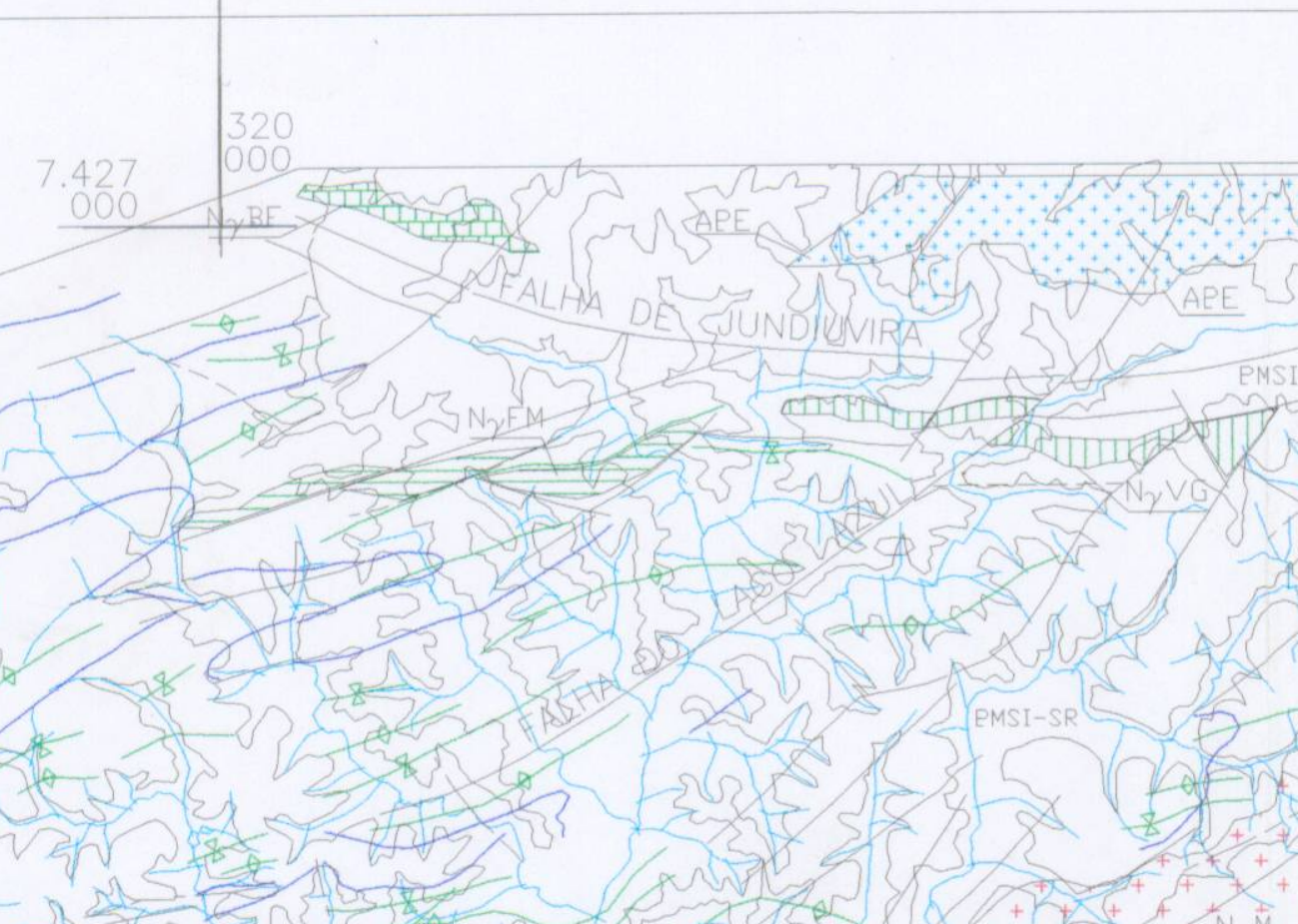

(n) $\frac{1}{20}+\frac{1}{2}$

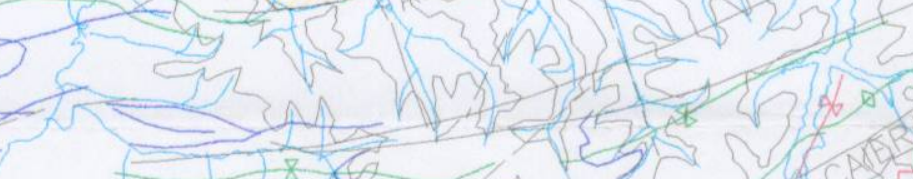
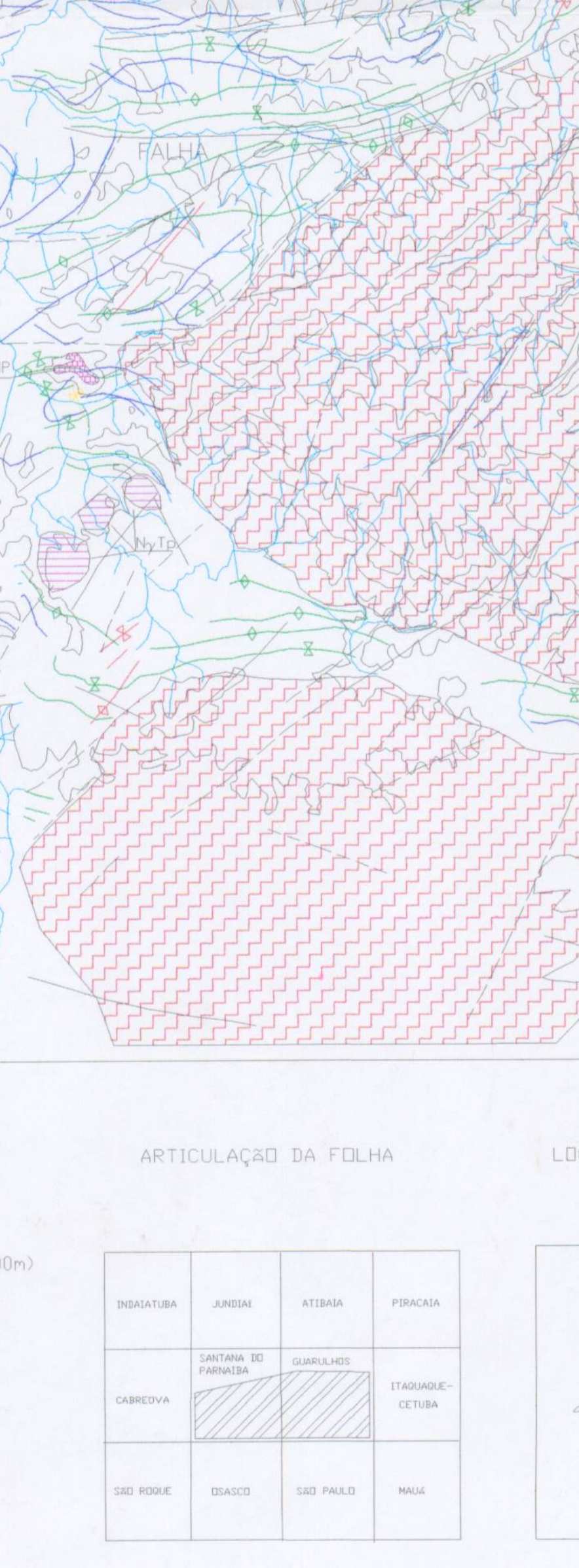

$\sum_{7.400}$

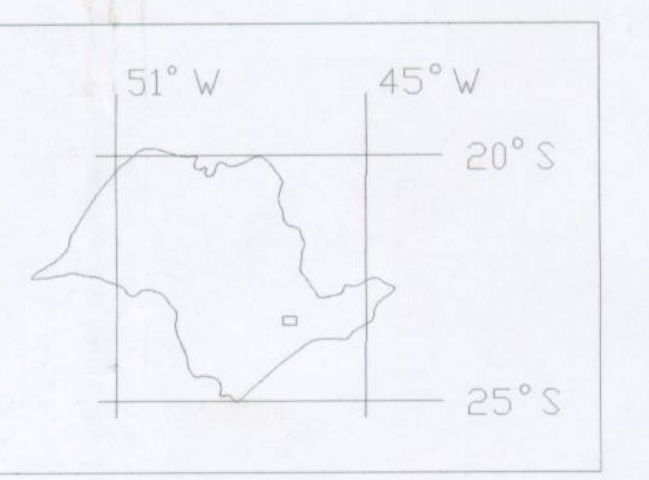

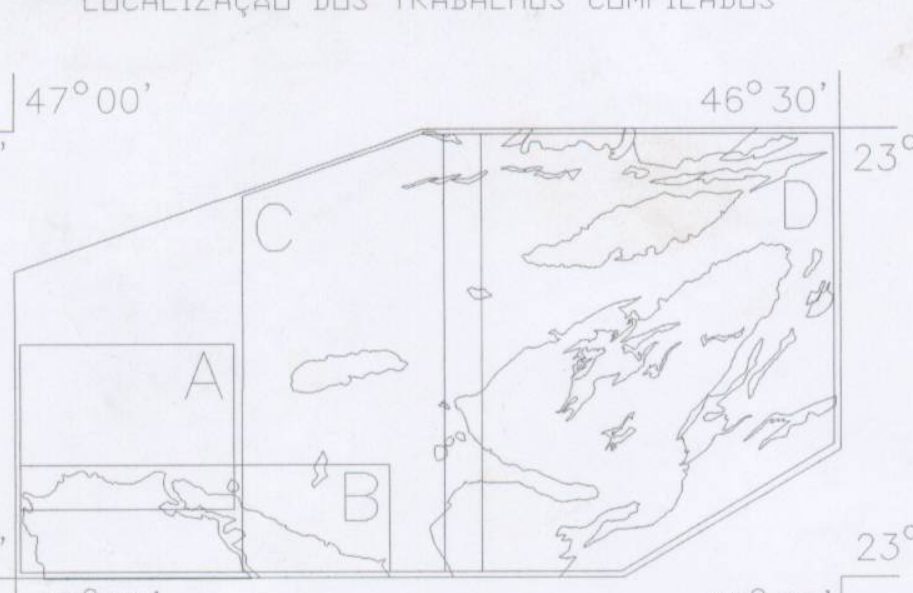

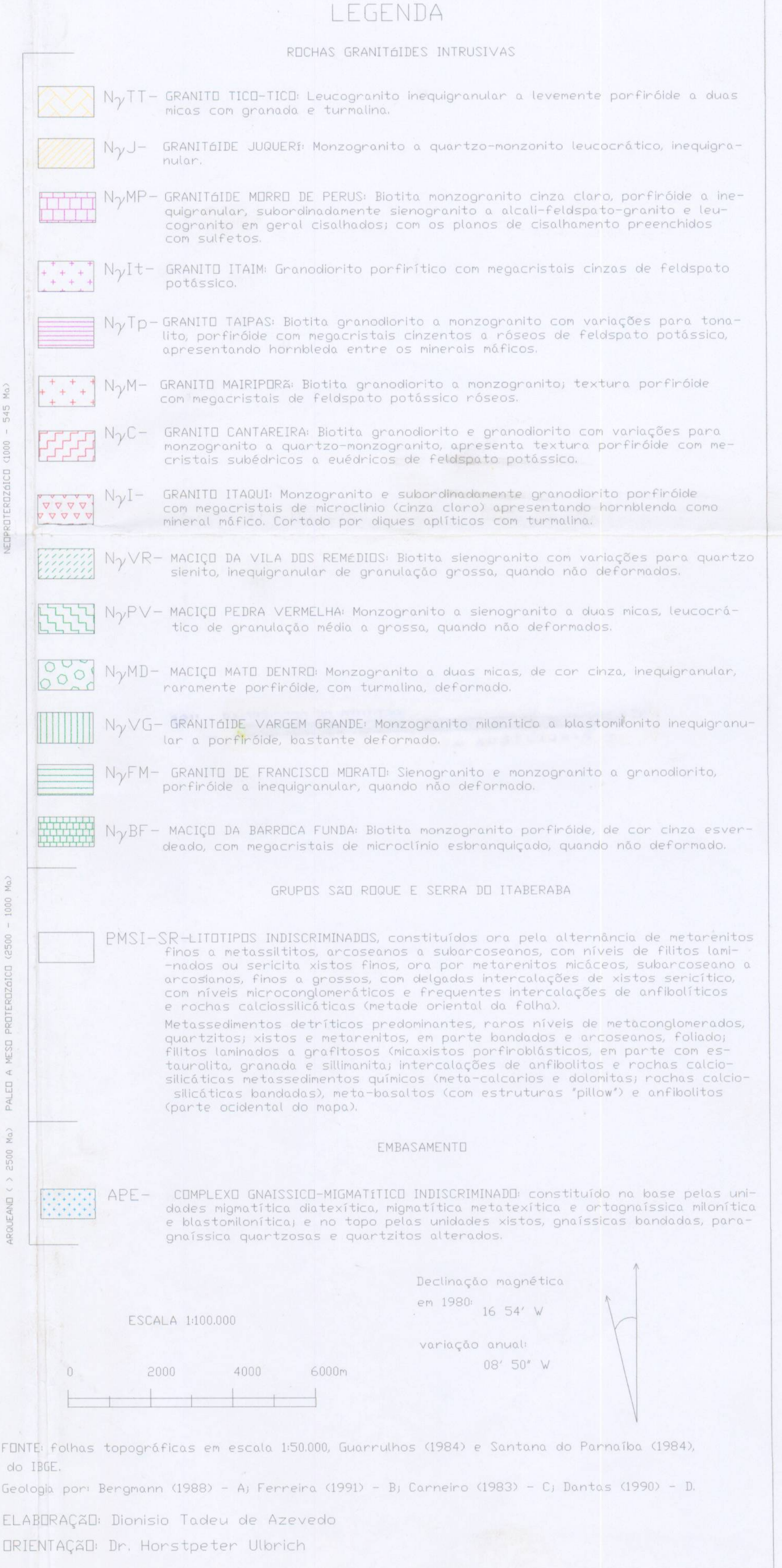


Anexo 2
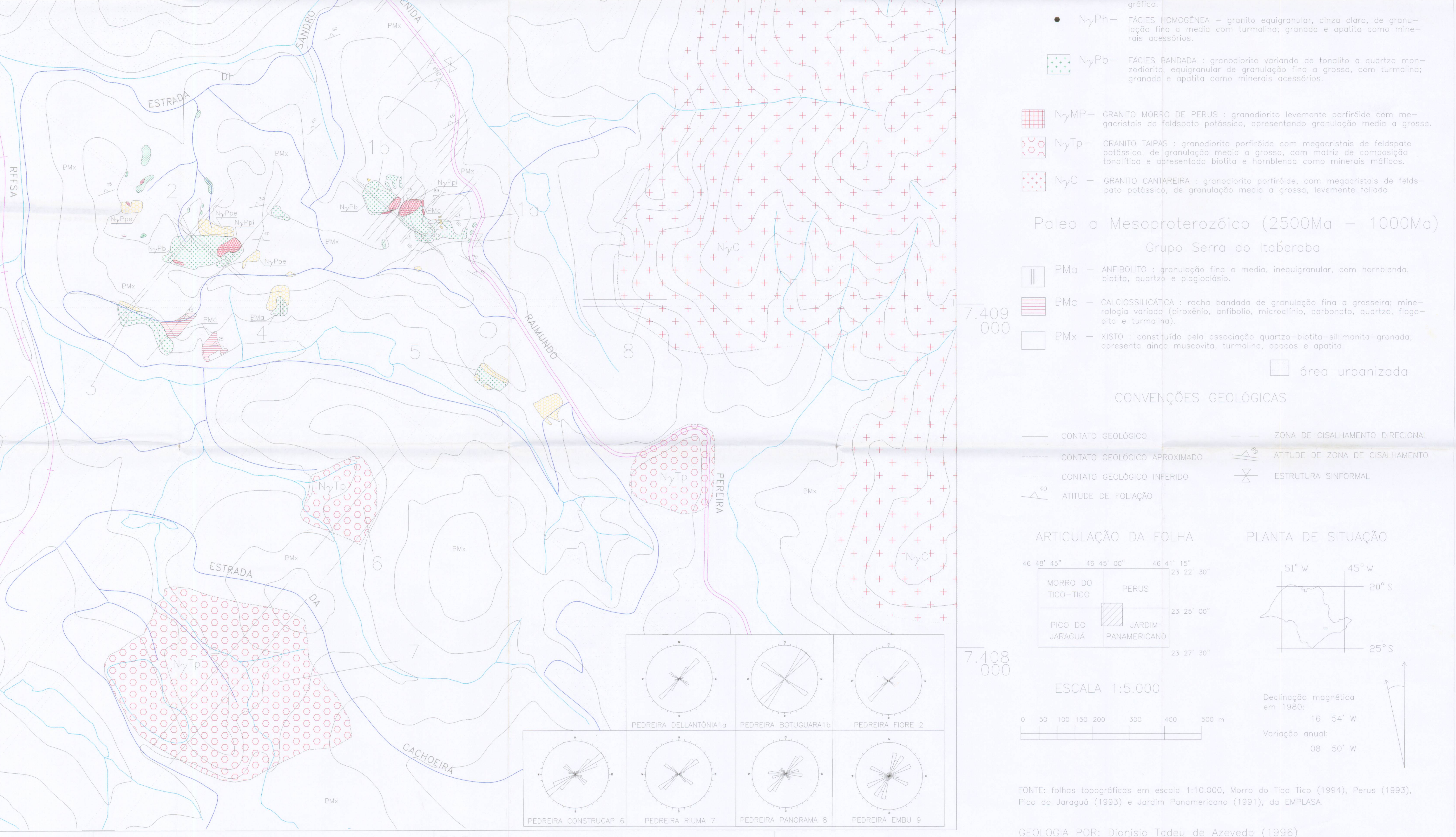


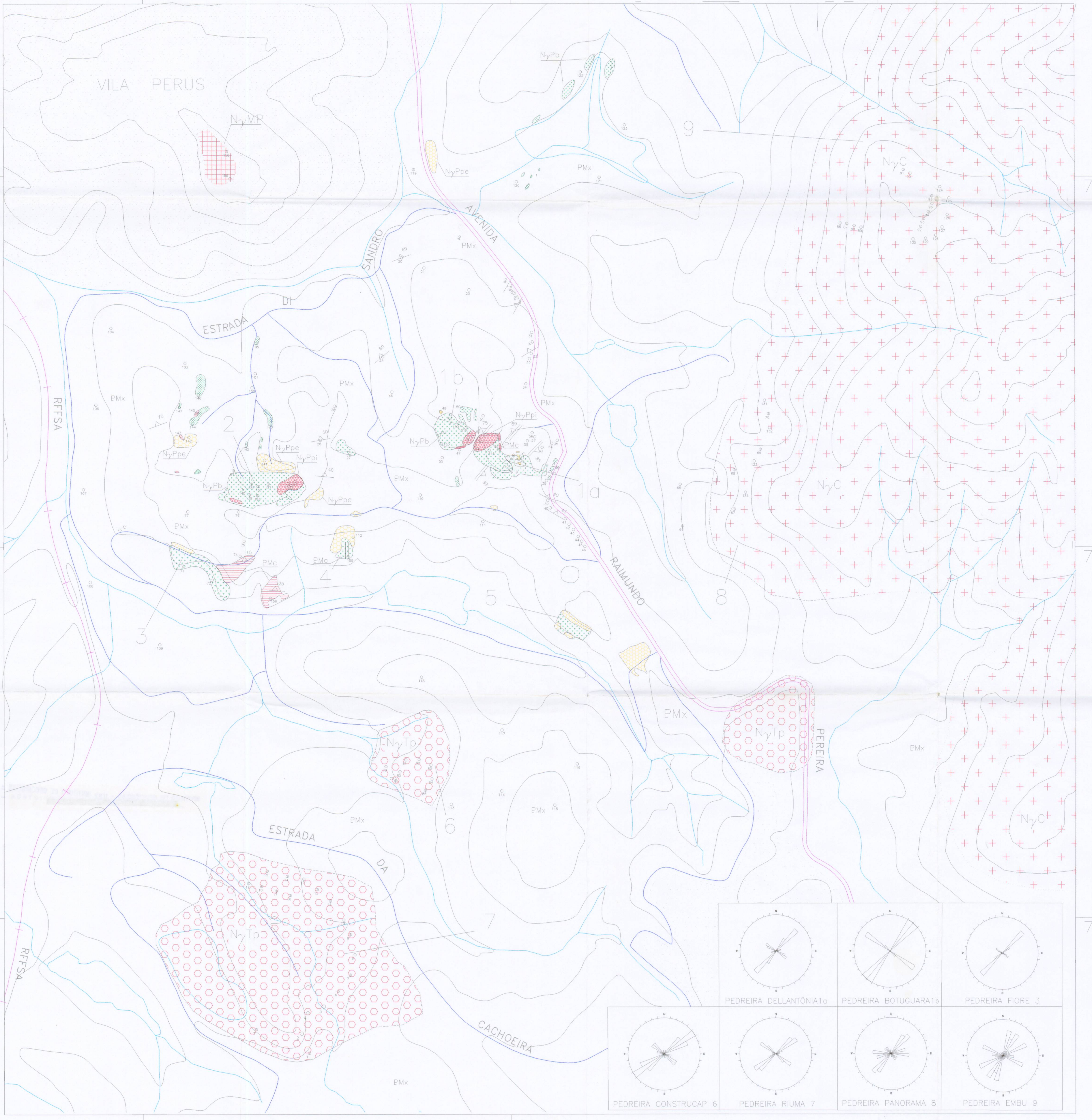

DA REGIT̃O DE PERUS, S.P.

Anexo 3

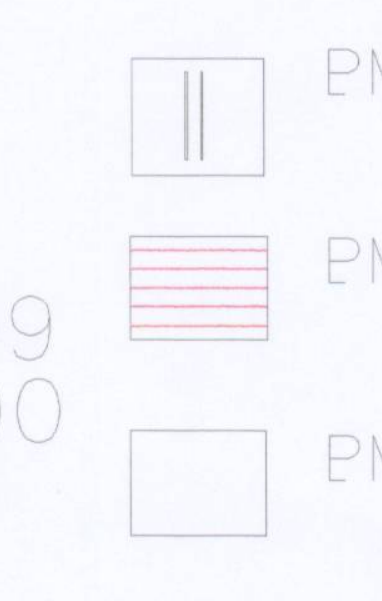

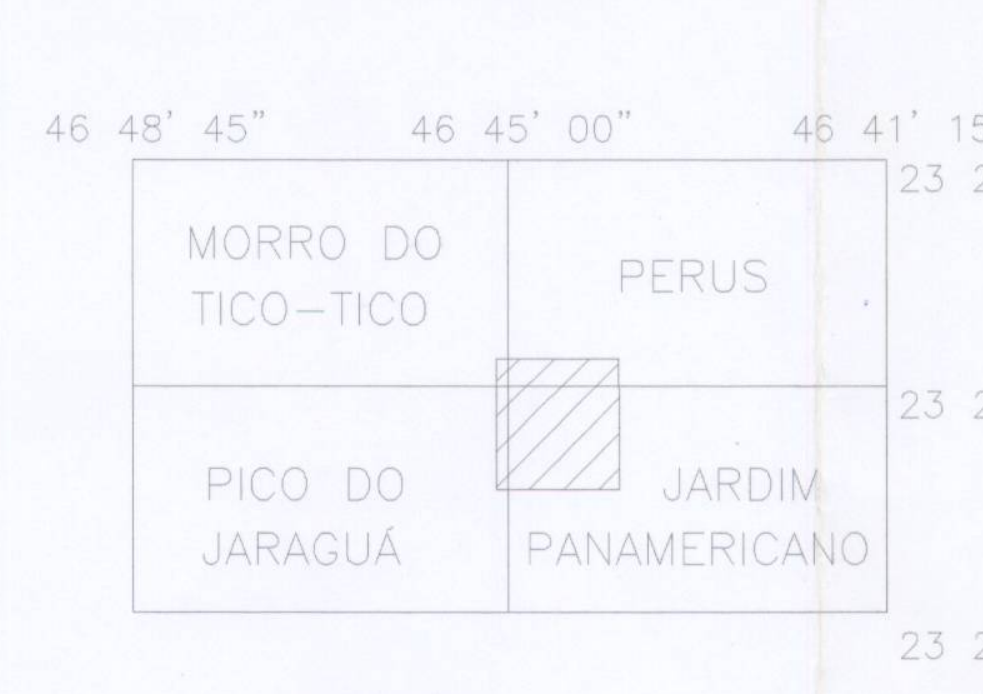

